\title{
Advanced Water-Cooled Phosphoric Acid Fuel Cell Development
}

\section{Final Report}

September 1992

Work Performed Uidder Contract No.: DE-AC21-88MC24221

For

U.S. Department of Energy

Office of Fossil Energy

Morgantovin Energy Technology Center

Morgantown, West Virginia

By

International Fuel Cells Corporation

South Windsor, Connecticut 


\section{DISCLAIMER}

This report was prepared as an account of work sponsored by an agency of the United States Government. Neither the United States Government nor any agency thereof, nor any of their employees makes any warranty, express or implied, or assumes any legal liability or responsibility for the accuracy, completeness or usefulness of any information, apparatus, product, or process disclosed, or represents that its use would not infringe privately owned rights. Reference herein to any specific commercial product, process, or service by trade name, trademark, manufacturer, or otherwise, does not necessarily constitute or imply its endorsement, recommendation, or favoring by the United States Government or any agency thereof. The views and opinions of authors expressed herein do not necessarily state or reflect those of the United States Government or any agency thereof.

This report has been reproduced directly from the best available copy.

Available to DOE and DOE contractors from the Office of Scientific and Technical Information, P.O. Box 62, Oak Ridge, TN 37831; prices available from (615)576-8401, FTS 626-8401.

Available to the public from the National Technical Information Service, U.S. Department of Commerce, 5285 Port Royal Rd., Springfield, VA 22161. 


\title{
Advanced Water-Cooled Phosphoric Acid \\ Fuel Cell Development
}

Final Report

Work Performed Under Contract No.: DE-AC21-88MC24221

For

U.S. Department of Energy

Office of Fossil Energy

Morgantown Energy Technology Center

P.O. Box 880

Morgantown, West Virginia 26507-0880

\author{
By \\ International Fuel Cells Corporation \\ 195 Governors Highway \\ South Windsor, Connecticut 06074
}

September 1992 


\section{TABLE OF CONTENTS}

Section

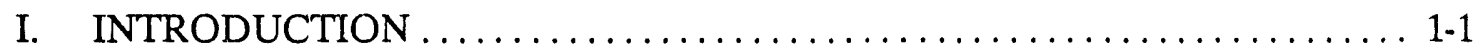

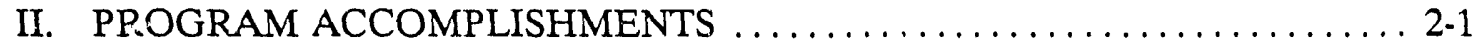

III. TASK DESCRIPTIONS AND RESULTS $\ldots \ldots \ldots \ldots \ldots \ldots \ldots \ldots \ldots \ldots \ldots$

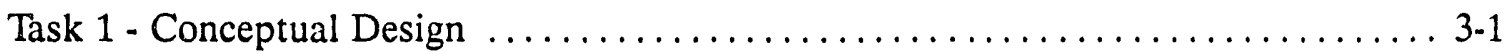

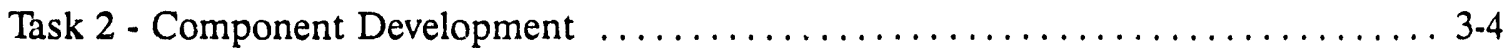

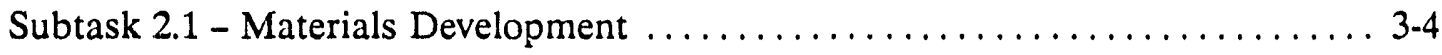

Subtask 2.2 - Single Cell Testing ........................... 3-6

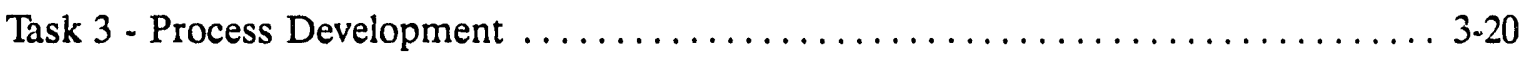

Subtask 3.1 - Substrates .................................. 3-20

Subtask 3.2 - Integral Separator ............................. 3-22

Subtask $3.3-$ Seals and Matrix . . . . . . . . . . . . . . . . . . . . . . . . 23

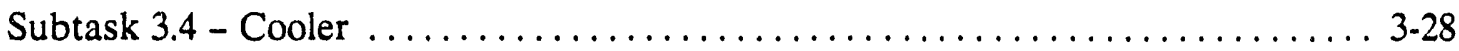

Task 4 - Stack Design .......................................... 3-35

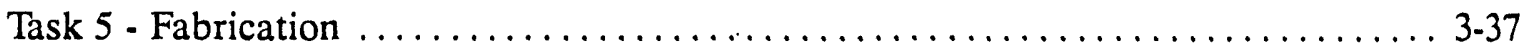

Subtask 5.1 - Repeat Components .......................... 3-37

Subtask 5.2 - Non-Repeat Components . . . . ................... 3-39

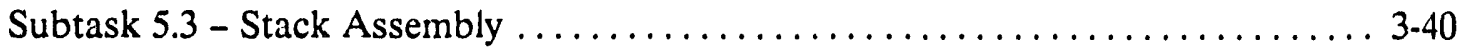

Subtask 5.4 - Cost Assessment ............................. 3-42

Task 6 - Stack Testing ...................................... 3-43

Subtask 6.1 - Small Area Development Stack Test . . . . . . . . . . . . . . . 3-43

Subtask 6.2 - Ten Square Foot Subscale Stack Test . . . . . . . . . . . . . . . . . . 3-54

Subtask 6.3 - On-Site Small Area Stack Test ..................... 3-62

Task 7 - Management And Documentation .......................... 3-70 


\section{LIST OF FIGURES}

Figure Page

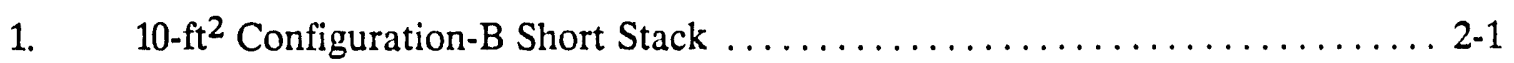

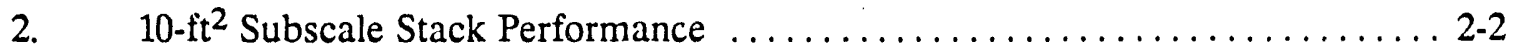

3. Small Area On-Site Stack Performance History $\ldots \ldots \ldots \ldots \ldots \ldots \ldots \ldots .2-2$

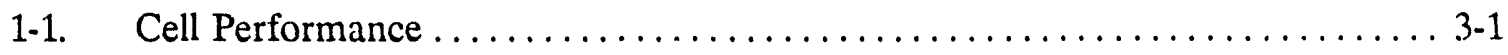

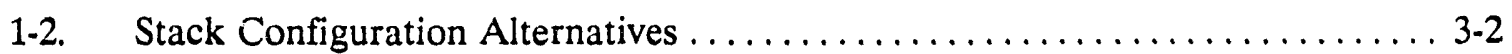

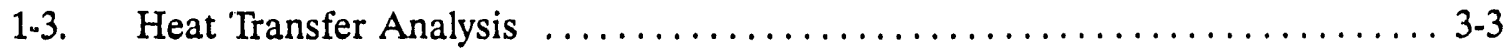

1-4. Acid Loss Analysis ............................... 3-3

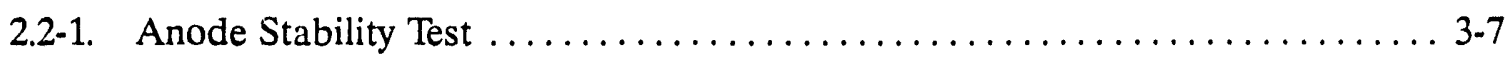

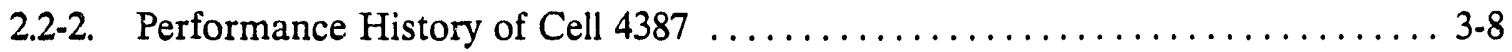

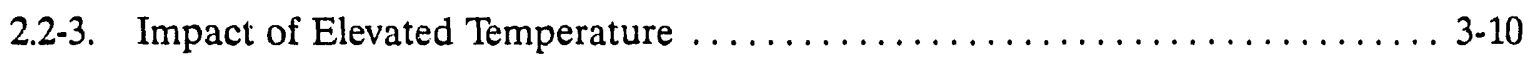

2.2-4. Subscale Cell 4473 Tracking the Small Area Development Stack .......... 3-11

2.2-5. Cell 4394 with $1 \mathrm{mg} / \mathrm{cm}^{2}$ Loading of GSB-18P .................. 3.13

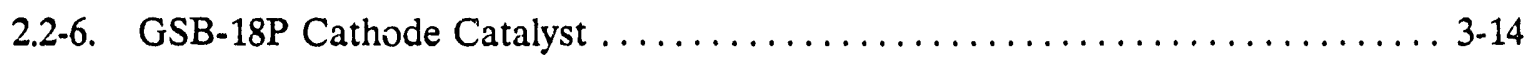

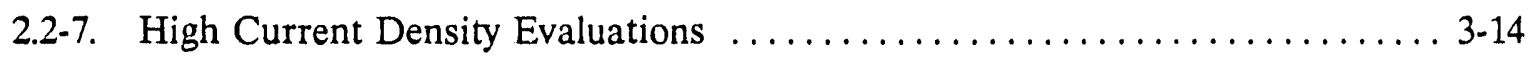

2.2-8. Performance History of Build 6751 GSB-18P Catalyst ............. 3-15

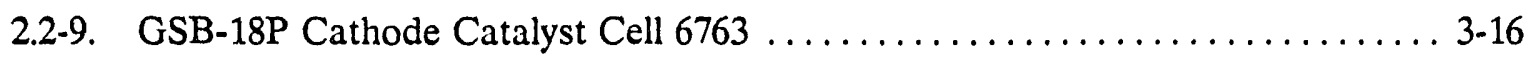

2.2-10. Performance History of Build 6774 GSB-18P Catalyst ............. 3-17

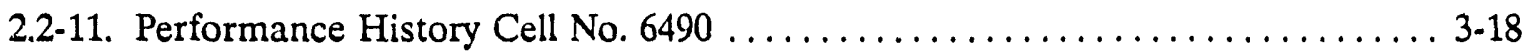

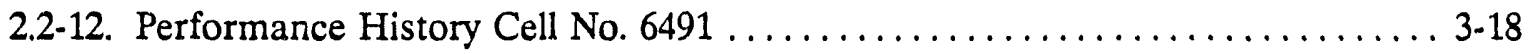

2.2-13. GSB-18P Catalyst At High Pressure Cell $6770 \ldots \ldots \ldots \ldots \ldots \ldots \ldots \ldots$. . . 19

3.1-1. Properties Comparison Vendor A vs. IFC Substrate ............... 3-21

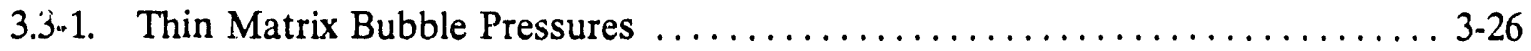

3.4-1. Thermal Resistance as Function of Thermal Cycling for Subscale

Molded Cooler ................................... 3-30

5.3-1. Vessel Dome Being Installed on $10-\mathrm{ft}^{2}$ Stack . . . . . . . . . . . . . . 3-41

6.1-1. Ambient Pressure Performance History of the Small Area Development Stack ................................ 3-45

6.1-2. Performance Calibration of the Small Area Development Stack .......... 3-46

6.1-3. Fuel Utilization Sensitivity of the Small Area Development Stack . . . . . . . . 3-46

6.1-4. Air Utilization Sensitivity of the Small Area Development Stack . . . . . . . . 3-47

6.1-5. Cross Pressure Response ............................. 3-48

6.1-6. Internal Resistance - Small Area Short Stack ................... 3-49

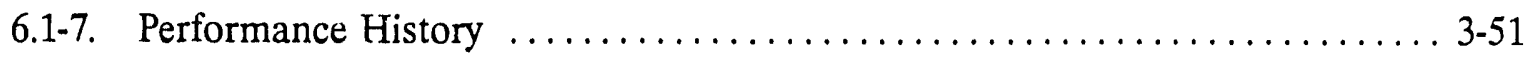

6.1-8 Small Area Development Stack Axial Load History $\ldots . \ldots \ldots \ldots \ldots \ldots \ldots$. $3-53$ 


\section{LIST OF FIGURES (Cont'd)}

Figure

Page

6.1-9. Acid Inventory of the Small Area Development Stack $3-53$

6.2-1. Average Cell Performance of the $10-\mathrm{ft}^{2}$ Subscale Stack 3-54

6.2-2. METC 10- $\mathrm{ft}^{2}$ Short Stack Time Line, March - September, 1991 $3-57$

6.2-3. 10- $\mathrm{Ft}^{2}$ Short Stack 3-58

6.2-4. METC 10- $\mathrm{Ft}^{2}$ Short Stack $3-58$

6.2-5. $10-\mathrm{Ft}^{2}$ Subsisale Stack Cell Performance at $200 \mathrm{ASF}$ $3-59$

6.2-6. Fuel Utilization Response of the $10-\mathrm{ft}^{2}$ Subscale Stack $3-59$

6.2-7. METC 10- $\mathrm{ft}^{2}$ Short Stack Average Air Util. Response 3-60

6.2-8. Average Cross Pressure Response of the10- $\mathrm{ft}^{2}$ Subscale Stack . 3-60

6.2-9. Axial Load History - 1st 10- $\mathrm{Ft}^{2}$ Subscale Stack 3-61

6.3-1. Small Area On-Site Short Stack Performance History $3-62$

6.3-2. METC On-Site Small Area ............................... 3-65

6.3-3. METC On-Site Small Area Stack - Performance Calibration ............. 3-65

6.3-4. METC On-Site Small Area Stack - Cell and Average Substack Performance . 3-66 6.3-5. METC Small Area On-Site Short Stack Fuel Utilization Sensitivity . . . . . . . 3-67

6.3-6. METC Small Area On-Site Short Stack Air Utilization Sensitivity . . . . . . . . 3-67

6.3-7. METC Small Area On-Site Short Stack Individual Cell iR Measurements . . . 3-68

6.3-8. METC Small Area On-Site Short Stack Cross Pressure Sensitivity . . . . . . . . 3-68

6.3-9. METC Smail Area On-Site Short Stack Hydrogen Gains 3-69 


\section{LIST OF TABLES}

Table

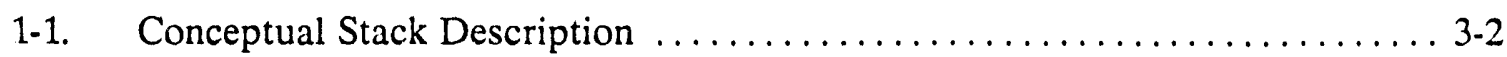

2-1-1. Thin Substrate Precursor Handsheet - Trial $2 \ldots \ldots \ldots \ldots \ldots \ldots \ldots \ldots \ldots \ldots \ldots \ldots \ldots$

2.1-2. One Step Heat Treat Electrolyte Reservoir Plates $\ldots \ldots \ldots \ldots \ldots \ldots \ldots \ldots . . \ldots .5$

2.1-3. ERP Fiber Reinforcement Comparison ..................... 3-5

2.2-1. GSB-18 Electrode Optimization Trials ...................... 3-8

2.2-2. Performance of Cells Simulating Short Stack .................. 3-9

2.2-3. Performance of Cells Tested at Elevated Cell Temperature . . . . . . . . . . . . 3-9

2.2-4. Performance of Cell Tracking the Small Area Development Stack ......... 3-10

2.2-5. Performance of Pressurized Single Cells $\ldots \ldots \ldots \ldots \ldots \ldots \ldots \ldots \ldots \ldots . \ldots . . \ldots \ldots$

2.2-6. Performance of Cell with GSB-18P Cathode Catalyst ................ 3-12

2.2-7. Performance of Cell with GSB-18P Cathode Catalyst .............. 3-12

2.2-8. Performance of Pressurized GSB-18P Single Cells $\ldots \ldots \ldots \ldots \ldots \ldots \ldots \ldots . \ldots \ldots$

2.2-9. GSB-18P Subscale Cells Tracking the $10-\mathrm{ft}^{2}$ Short Stack ............ 3-16

3.3-1. Bubble Pressure Results Full-Size On-Site Cells $\ldots \ldots \ldots \ldots \ldots \ldots \ldots \ldots . . \ldots \ldots$

3.3-2. Curtain Coated Thin Matrix Bubble Pressure $\ldots \ldots \ldots \ldots \ldots \ldots \ldots \ldots . \ldots . . \ldots .25$

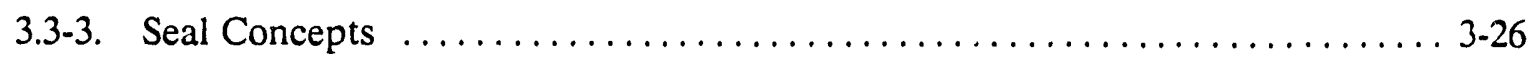

3.4-1. Thermal Conductivity of Molded Cooler Composites ................. 3-28

3.4-2. Post Bake Results for Subscale Graphite-Resin Composites . . . . . . . . . . . 3-29

3.4-3. Thermal Performance Comparison ......................... 3-30

3.4-4. Commercial Graphite Cooler Holder - Physical Properties ............. 3-31

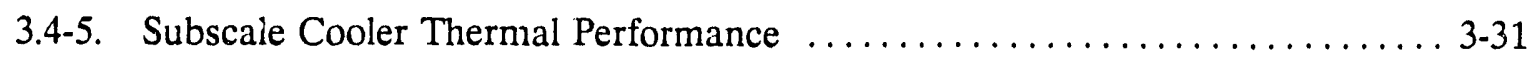

3.4-6. Small Area Cooler Performance . ......................... 3-32

3.4-7. Cooler Edge Seal Encapsulation Approaches .................... 3-33

3.4-8. Cooler Edge Seals Encapsulation Trials ....................... 3-33

3.4-9. Dye Test Results for Subscale Encapsulation Coolers With Separator Fluoropolymer Film Edge Seals ........................... 3-34

4.1-1. Small Area Developmer ${ }_{t}$ Stack Description .................... 3-35

4.1-2. First $10-\mathrm{ft}^{2}$ Subscale Stack Description $\ldots \ldots \ldots \ldots \ldots \ldots \ldots \ldots \ldots . \ldots \ldots . \ldots \ldots$

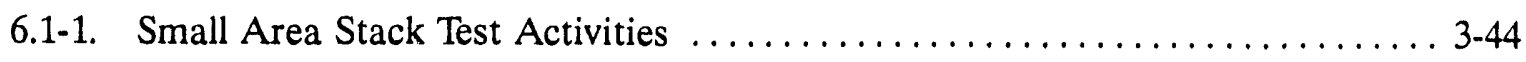

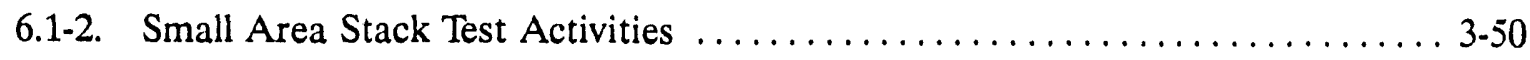

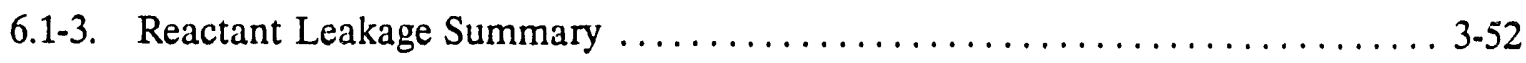

6.2-1. $10-\mathrm{ft}^{2}$ Stack No. 1 Test Activities ......................... 3-56

6.2-2. Reactant Leakage History $10-\mathrm{ft}^{2}$ Subscale Stack .................. 3-61

6.3-1. On-Site Small Area Stack Test Activities ...................... 3-63

6.3-2. Small Area On-Site Stack Reactant Leakage ..................... 3-69 
I. INTRODUCTION 


\section{INTRODUCTION}

The Advanced Water Cooled Phosphoric Acid Fuel Cell Development program was conducted by International Fuel Cells Corporation (IFC) to improve the performance and minimize the cost of existing water-cooled phosphoric acid fuel cell stacks for electric utility and on-site applications. The goals for the electric utility stack technology were a power density of at least 175 watts per square foot over a 40,000-hour useful life and a projected one-of-a-kind, full-scale manufactured cost of less than $\$ 400$ per kilowatt.

The program adapted the existing on-site Configuration-B cell design to electric utility operating conditions and introduced additional new design features. Task 1 consisted of the conceptual design of a full-scale electric utility cell stack that meets program objectives. The conceptual design was updated to incorporate the results of material and process developments in Tasks 2 and 3, as well as results of stack tests conducted in Task 6. Tasks 2 and 3 developed the materials and processes required to fabricate the components that meet the program objectives. The design of the small area and $10-\mathrm{ft}^{2}$ stacks was conducted in Task 4 . Fabrication and assembly of the short stacks were conducted in Task 5 and subsequent tests were conducted in Task 6 . The management and reporting functions of Task 7 provided DOE/METC with program visibility through required documentation and program reviews.

This report describes the cell design and development effort that was conducted to demonstrate, by subscale stack test, the technical achievements made toward the above program objectives. 


\section{PROGRAM ACCOMPLISHMENTS}




\section{PROGRAM ACCOMPLISHMENTS}

The conceptual design of a full-height cell stack for electric utility applications was defined to guide component development activities toward meeting program objectives for power density and cost. The design utilized $35510-\mathrm{ft}^{2}$ Configuration-B cells to produce over $1-\mathrm{MWdc}$ power.

Subscale Configuration-B cells with GSB-18P cathode catalyst achieved the initial performance uscd in the Conceptual Design. The demonstrated performance of 0.75 volts per cell at 400 ASF corresponded to a power density of $300 \mathrm{WSF}$ (well above the program goal of $175 \mathrm{WSF}$ ). Approaches to lower the cost and improve the integrity of components such as intercell separators, seals, and coolers were defined and verified in a small area development stack for over 3000 hours before scaleup to $10-\mathrm{ft}^{2}$ size parts.

The $10-\mathrm{ft}^{2}$ Configuration-B cell stack pictured in Figure 1 was built and tested for over 3000 hours at pressurized operating conditions appropriate for electric utility applications. The stack demonstrated operation up to $400 \mathrm{ASF}$, achieving a power density of 285 WSF (nearly $65 \%$ beyond the 175 WSF program goal). See Figure 2.

An advanced small area on-site stack was also successfully tested for over 4500 -hours. As shown in Figure 3, performance and stability were very good throughout the testing. Performance decay was less than $4 \mathrm{mV}$ per 1000-hours during simulated on-site power plant operation.

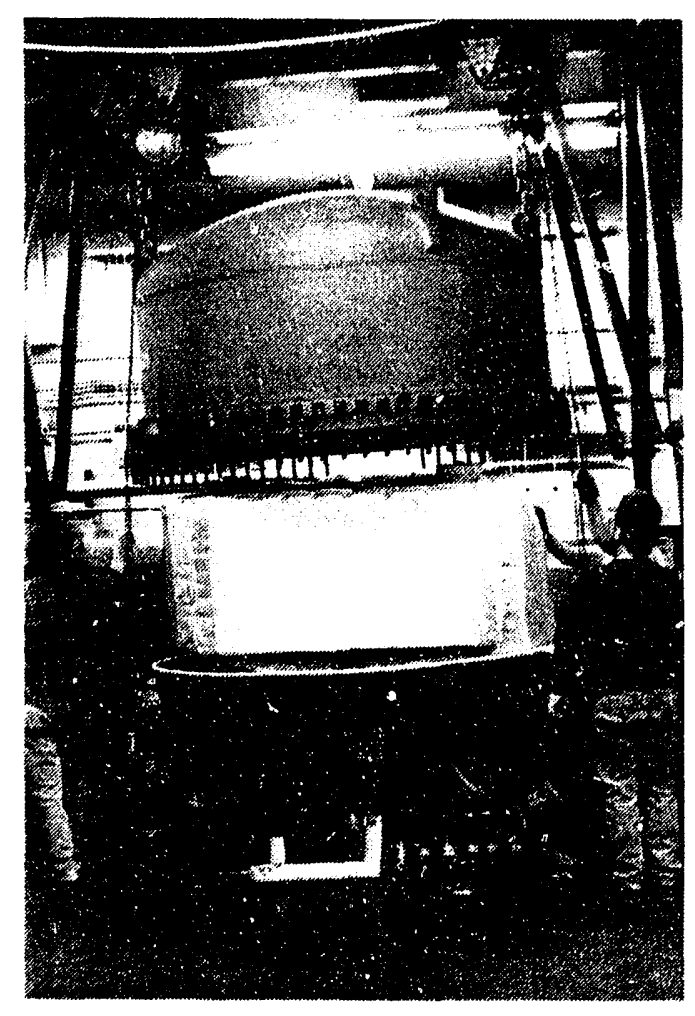

PUBS 8249

Figure 1. 10-ft ${ }^{2}$ Configuration-B Short Stack 


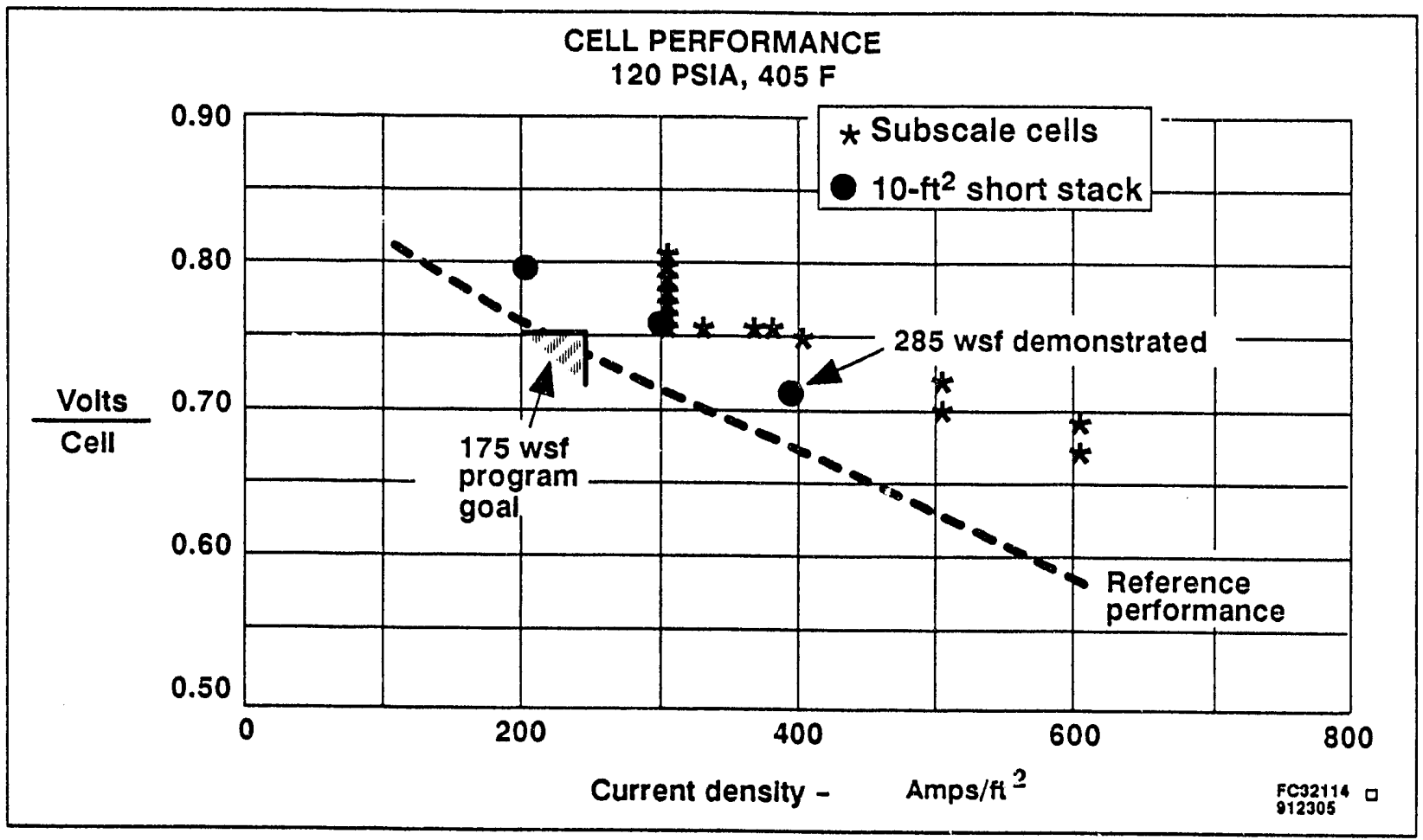

Figure 2. 10- $\mathrm{ft}^{2}$ Subscale Stack Performance

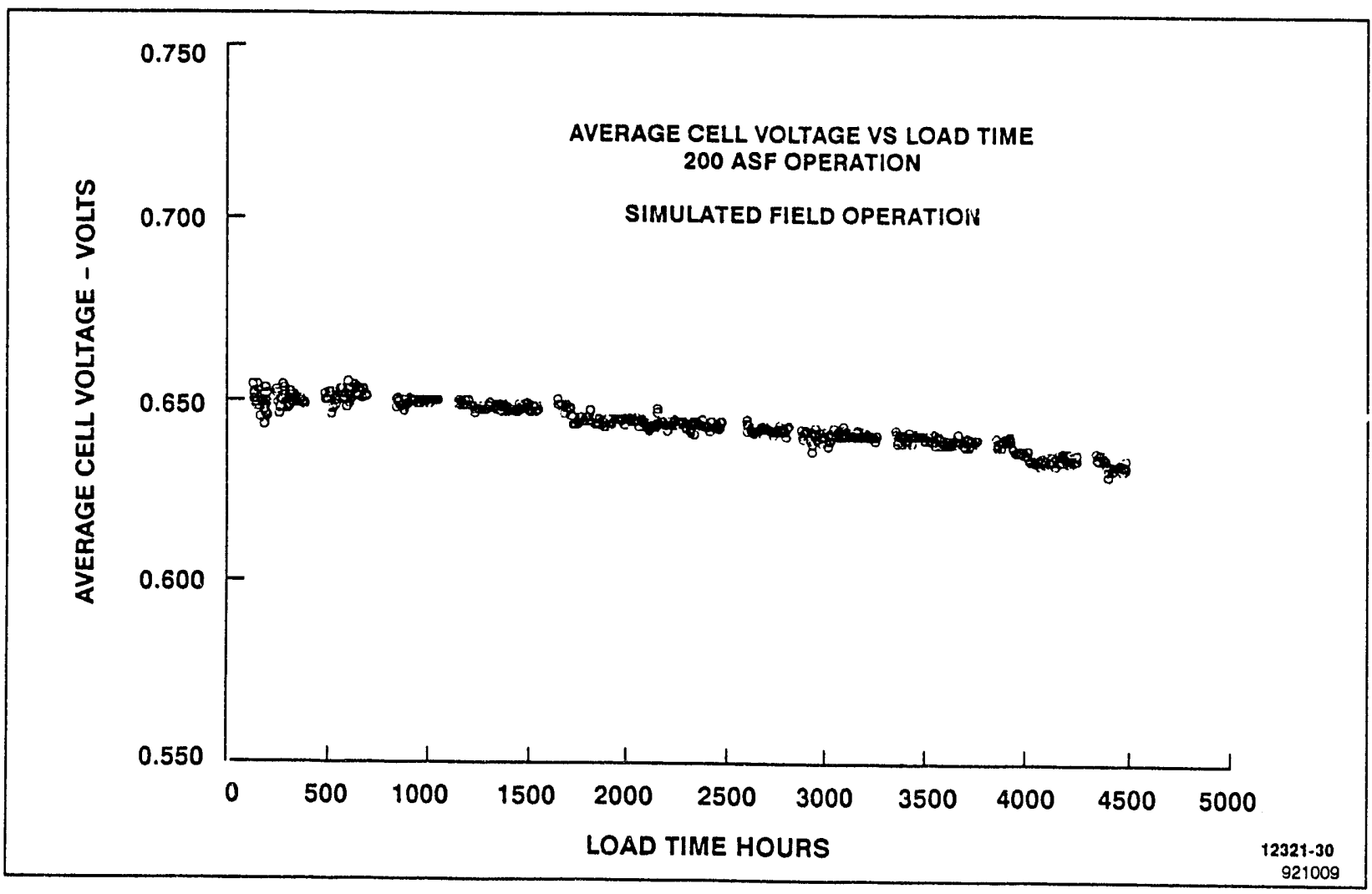

Figure 3. Small Area On-Site Stack Performance History 


\section{TASK DESCRIPTIONS AND RESULTS}




\section{TASK DESCRIPTIONS AND RESULTS}

\section{TASK 1 - CONCEPTUAL DESIGN}

\section{Objectives}

The objective in this task is to define the conceptual design for a cell stack having a performance level of at least 175-WSF and a manufactured cost of less than $\$ 400 / \mathrm{kW}$. The stack must be capable of operating for a minimum of 40,000 hours at electric utility conditions.

\section{Summary}

The conceptual design was based on achieving 0.75 volts per cell at 400 ASF as demonstrated by subscale cells in Subtask 2.2. See Figure 1-1. This corresponds to power density of 300 WSF which is approximately 70 percent above the $175 \mathrm{WSF}$ program goal.

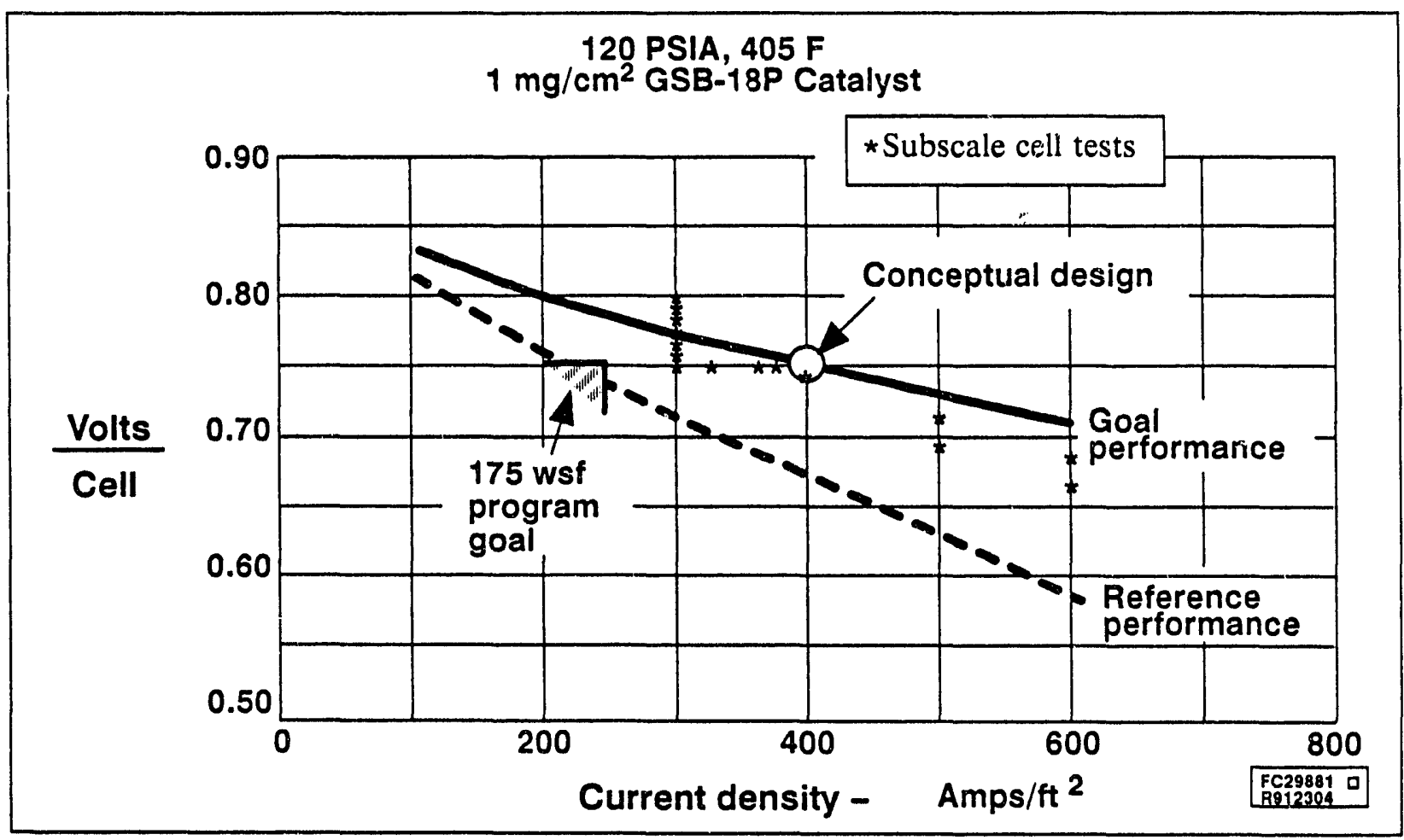

Figure 1-1. Cell Performance

Design studies were conducted to define the cell active area, cooler spacing, and flow field configuration. A cell active area of $10-\mathrm{ft}^{2}$ was selected, and coolers were spaced every five cells.

Conceptual design drawings were prepared for a complete cell stack. The overall assembly drawing showed the arrangement within the pressure vessel of all major non-repeat and repeat parts. Conceptual drawings of the individual repeat parts were also prepared based on drawings from the subscale $10-\mathrm{ft}^{2}$ stack and included in this package. As shown in Figure 1-2, the conceptual design is expected to produce $1050 \mathrm{~kW}$ in the same height and volume as the present $670-\mathrm{kW}$ PC23 cell stack. This represents a 56 percent increase in power output from the same size package. 


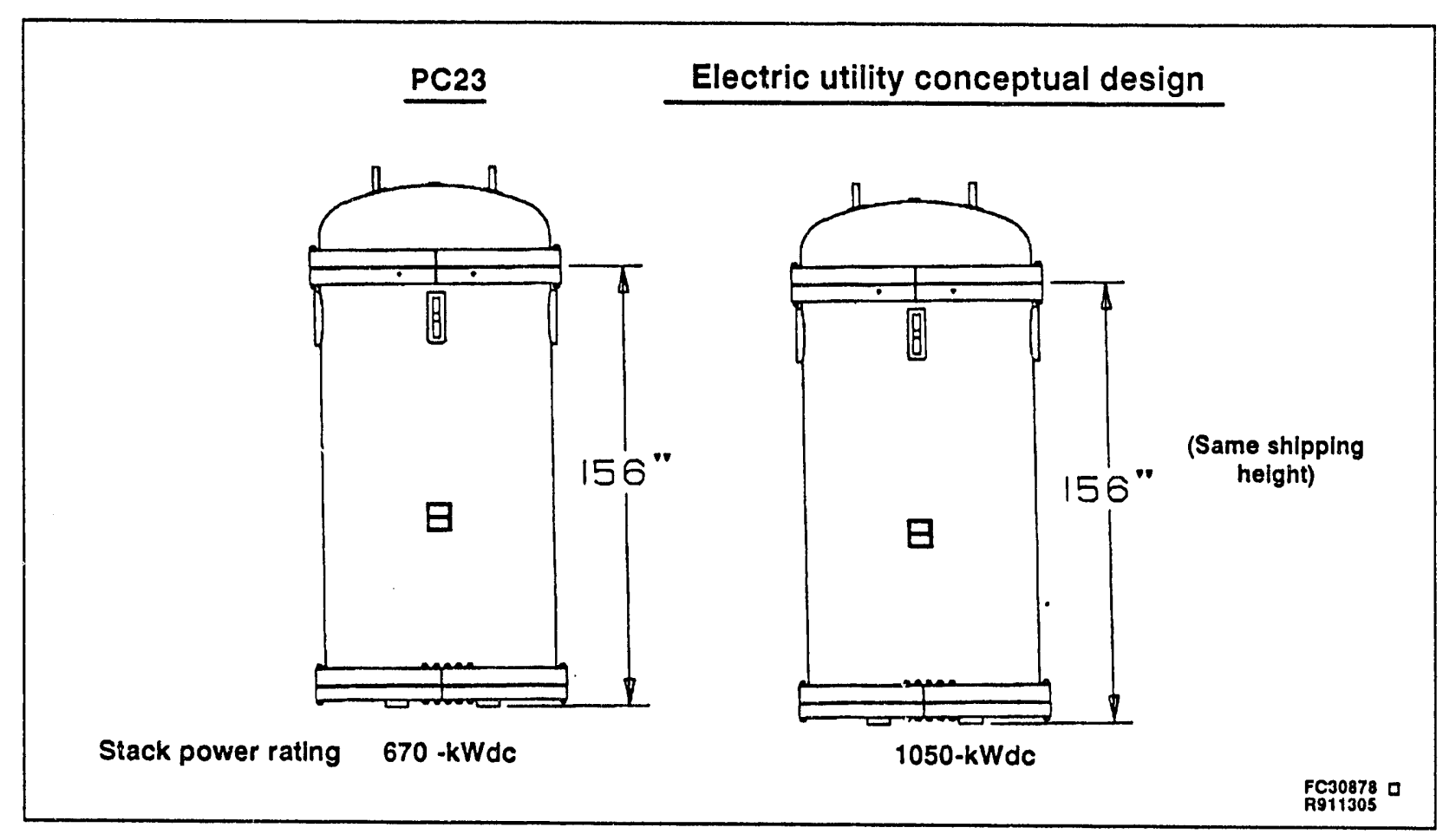

Figure 1-2. Stack Configuration Alternatives

\section{Discussion of Activities}

The conceptual design of a full-scale cell stack was first completed in 1988 and then periodically updated to reflect information learned during design, fabrication, and test of the small area development stack and the $10-\mathrm{ft}^{2}$ subscale stack.

A general description of the final conceptual design is listed in Table 1-1. As shown in Figure 1-3, design calculations were performed to support the selection of five cells per cooler. A projection of acid loss from the cell stack was also made. As shown in Figure 1-4, the 40,000 hours minimum operating life can be met without acid refill.

Table 1-1. Conceptual Stack Description

- $10-\mathrm{ft}^{2}$ active area Configuration "B" cells with GSB-18P cathode catalyst

- 355 cells

- 5 cells per cooler, 71 substacks

- Advanced commercial graphite coolers

- Integral end-plates

- Coated carbon steel manifolds

- 150 psig MAWP vessel 


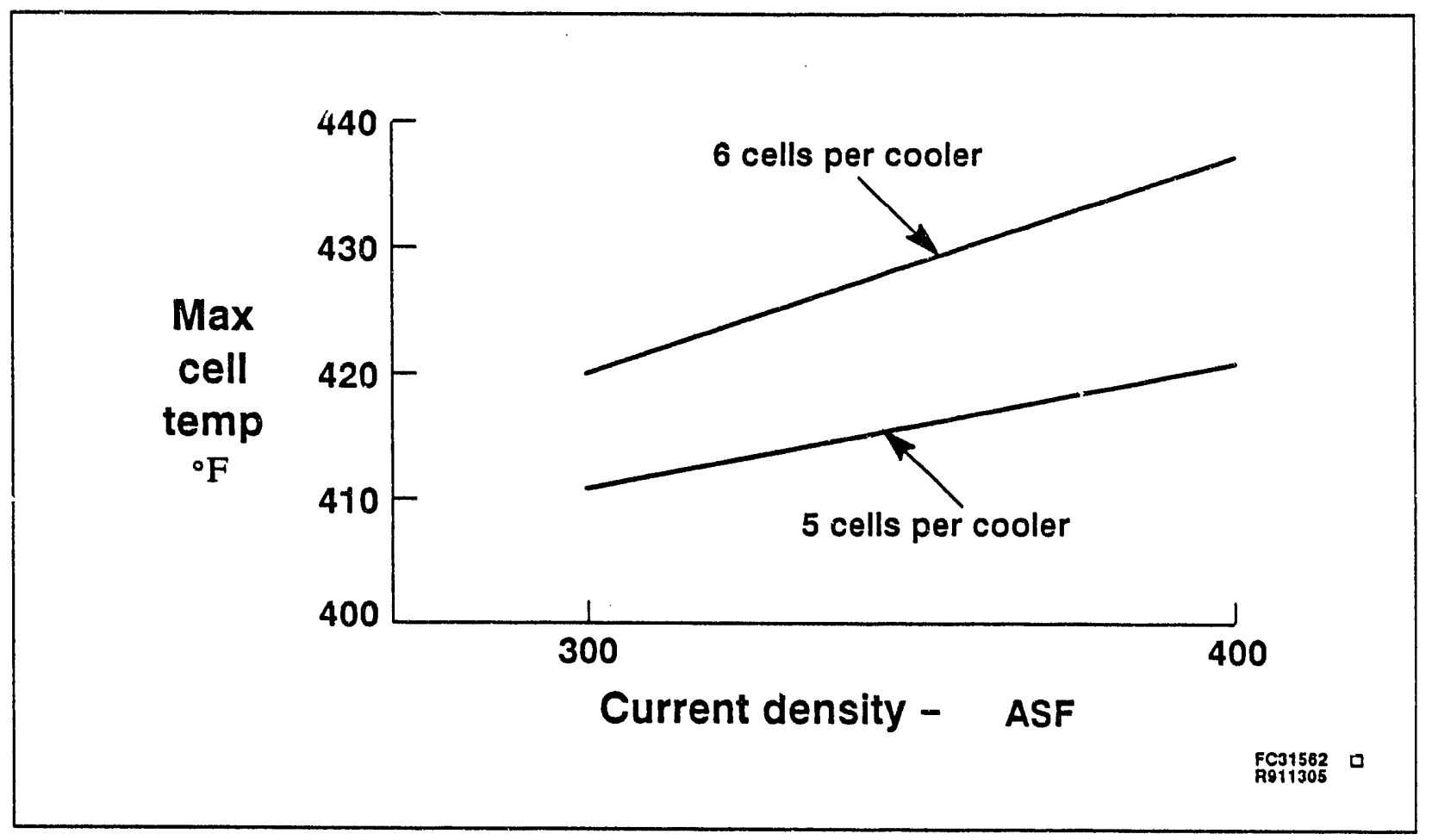

Figure 1-3. Heat "'ransfer Analysis

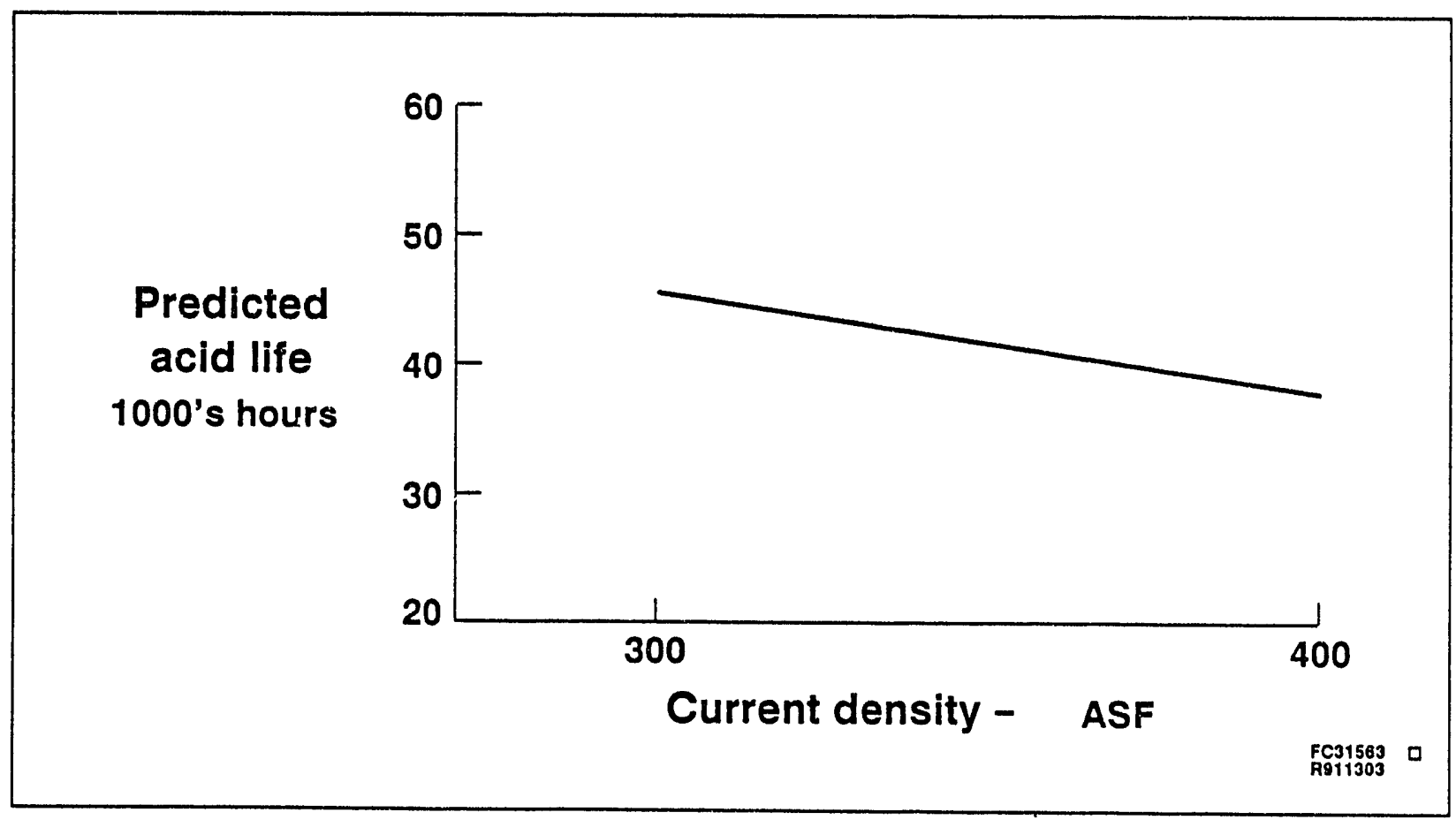

Figure 1-4. Acid Loss Analysis 


\section{TASK 2 - COMPONENT DEVELOPMENT}

\section{Subtask 2.1 - Materials Development}

\section{Objectives}

The objectives of this subtask are to provide an improved substrate, verify the stability of low cost substrate and electrolyte reservoir materials at pressurized cell operating conditions and increase the thermal conductivity of the electrolyte reservoir.

\section{Summary}

Substrate and electrolyte reservoir materials which were prepared as part of process development activities in Subtask 3.1 were evaluated. Material properties measurements indicated that these materials were acceptable for use in either ambient or pressurized applications.

\section{Discussıon of Activities}

Graphitized handsheets of thin substrates which were prepared in Subtask 3.1 were characterized to determine their physical properties. The measured properties, with the exception of the electrical resistance, met requirements as shown in Table 2.1-1. Since the discrepancy in electrical resistance was expected to produce only a small performance loss, target values of density and thickness were selected for a full-size precursor forming trial. After forming, substrate precursors were heat treated and then used to build subscale (2-inch by 2-inch) cells. As reported in Subtask 2.2, the performance of these cells was acceptable.

\begin{tabular}{|lcrrrrrrr|}
\hline \multicolumn{1}{|c}{ Table 2.1-1.Thin Substrate Precursor Handsheet - Trial 2 } \\
\hline & $\begin{array}{c}\text { Target } \\
\text { Value }\end{array}$ & A3 & B3 & C3 & A5 & B5 & C5 \\
\hline & $.35-.50$ & .39 & .37 & .41 & .38 & .40 & .36 \\
\hline Density, GM/CC & $100 \mathrm{Min}$ & 104 & 129 & 117 & 103 & 123 & - \\
Comp. Strength, Psi & $300 \mathrm{Min}$ & 1247 & 1348 & 922 & 1077 & 1297 & 976 \\
Flex, Strength, Psi & $.025 \mathrm{Max}$ & .085 & .081 & .080 & .083 & - & - \\
Elec. Resistance, mV/Mil/ & & & & & & & \\
WO ASF & $1150 \mathrm{Min}$ & 1269 & 1240 & 1224 & 1250 & 1238 & 1241 \\
Corrosion Potential, mV & & & & & & & \\
\hline
\end{tabular}

The possibility of performing one-step heat treat of Electrolyte Reservoir Plates (ERP's) was also considered in Subtask 3.1. Results of properties tests are shown in Table 2.1-2. The results indicate that electrolyte reservoir plates which were heat treated in a one-step process satisfied requirements.

Electrolyte reservoir plates which were formed with both carbon fiber and natural fiber in an attempt to lower cost and heat treated by the 2-step process were also evaluated. As shown in Table 2.1-3, properties for the ERP made with natural fiber are similar to properties with the carbon fiber. Both materials are acceptable for use in cells.

The long-term stability of the corrosion potential of Configuration-B substrates was also checked. In order to do this, an improved test rig configuration was used to demonstrate that test conditions could be held constant over the expected duration of the corrosion potential test. Once this was completed, 
the corrosion potential of selected cell material specimens was measured in order to evaluate the repeatability of the data and to compare the data with previous readings from an earlier corrosion test rig. This data was found to agree well with values reported in Tables 2.1-1 and 2.1-3.

\begin{tabular}{|lcc|}
\hline & $\begin{array}{c}\text { Table 2.1-2. One Step Heat Treat } \\
\text { Electrolyte Reservoir Plates }\end{array}$ & \\
\hline \multicolumn{1}{|c|}{ Property } & Targets & Measured \\
\hline Density (g/cc) & $0.90-1.25$ & 1.07 \\
$\begin{array}{l}\text { Compressive Yield Strength } \\
(\text { psi) }\end{array}$ & $>125$ & 370 \\
$\begin{array}{l}\text { Compressive Modulus (psi) } \\
\text { Flexural Strength (psi) }\end{array}$ & $>350$ & 12,759 \\
$\begin{array}{l}\text { Electrical Resistance } \\
\text { (mV/mil @ 100 ASF) } \\
\text { Thermal Conductivity } \\
\left(\text { Btu/HrFt }{ }^{\circ} \mathrm{F}\right)\end{array}$ & $<0.01$ & 723 \\
Corrosion Potential (mV) & $>8.0$ & 0.002 \\
\hline
\end{tabular}

\begin{tabular}{|lccc|}
\hline \multicolumn{3}{c|}{$\begin{array}{c}\text { Table 2.1.3. } \\
\text { ERP Fiber Reinforcement } \\
\text { Comparison }\end{array}$} & \\
\hline \multicolumn{1}{|c|}{ Target } & Carbon Fiber & Natural Fiber \\
\hline Density (g/cc) & $0.9-1.25$ & 1.10 & 1.13 \\
Compressive Yield Strength (psi) & $>125$ & 499 & 468 \\
Compressive Modulus (psi) & - & 17,461 & 19,660 \\
Flexural Strength (psi) & $>350$ & 1265 & 1531 \\
Electrical Resistance (mV/mil) & $<0.01$ & 0.002 & 0.003 \\
Thermal Conductivity $\left(\mathrm{Btu} / \mathrm{HrFt}{ }^{\circ} \mathrm{F}\right)$ & $>8.0$ & 12.8 & 9.3 \\
Corrosion Potential $(\mathrm{mV})$ & $>1150$ & 1180 & 1160 \\
& & & \\
\hline
\end{tabular}




\section{Subtask 2.2 - Single Cell Testing \\ Objective}

The objectives of this subtask are to test subscale cells to evaluate improvements in cell components including substrates, electrolyte reservoir plates, catalyst and matrix; verify performance and endurance of components fabricated for short stacks; optimize the hydrophobicity of catalyst layers made from the GSB-18 and GSB-18P catalyst for operation at power densities of $200 \mathrm{WSF}$ or greater; evaluate a higher performing laboratory catalyst for this application, and define the permissible range of operating conditions.

\section{Summary}

Cell development activities focused on defining stable anode and cathode catalyst layers for ambient and pressurized operation. Both GSB-18 and GSB-18P cathode catalysts were used in performance optimizations. Some cells with GSB-18P catalyst nearly achieved the 300 WSF conceptual design point ( 0.75 volts at $400 \mathrm{ASF})$.

\section{Discussion of Activities}

Test activities focused on demonstrating corfigurations required for upcoming short stack tests. As described in the following sections, different substrates, catalysts, and catalyst layer compositions and processing conditions were evaluated.

(1) Anode Stability Evaluations

Cell 4315 was built to evaluate the effect of anode sinter temperature and cell pinch on performance. The cell accumulated over 3700-hours of operation. The initial and final performance at 300 ASF was 0.620 volts and 0.578 volts, respectively.

Another set of cells $(4384,4385)$ were run to establish the stability of the new anode structures. All previous testing of the improved anodes indicated good stability; however, tests to establish improved anode stability generally require long test times. Therefore an accelerated test program was needed to evaluate the new structures in a reasonable time period. It has been determined, from previous testing at IFC, that putting cells through a shutdown cycle which solidifies the electrolyte can lead to significant decay of the anode. A test program with "freeze" cycles was chosen and one cell with the standard HYCAN anode (4384) was also evaluated at the same time as the new improved anode (4385). The cathodes in both of these cell tests are standard electrodes. Hydrogen gains for the two cells are plotted in Figure 2.2-1 before and after the first five (5) "freeze" cycles. Throughout the freeze cycles the improved anode was very stable and performed better on an absolute basis than the standard anode. 


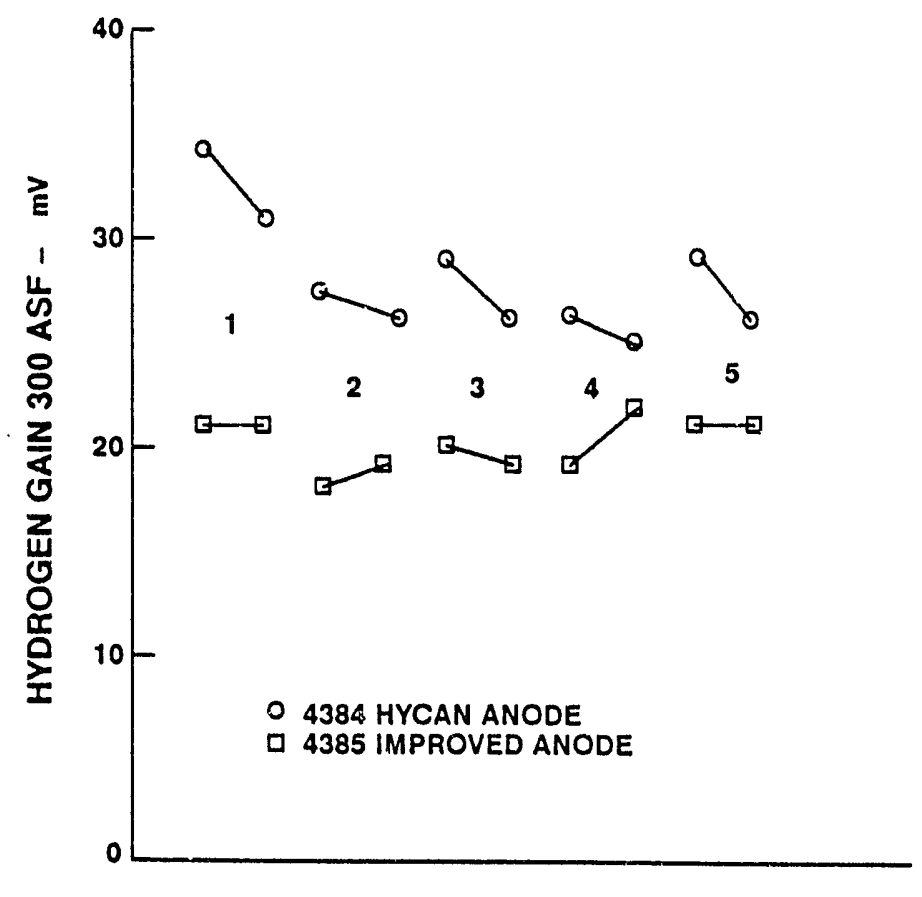

FREEZE CYCLE

Figure 2.2-1. Anode Stability Test

(2) GSB-18 Catalyst Qualification and Optimization

Cell 4387 was built to qualify catalyst for the small area development. This cell, containing electrodes made in the laboratory, performed at $20 \mathrm{mV}$ above E-line at $300 \mathrm{ASF}$ after 1500-hours of operation and, therefore, served to qualify catalyst. A complete history of cell 4387 at 300 ASF is shown in Figure 2.2-2.

Following qualification of catalyst for the small area short stack, nineteen (19) subscale cells were run to determine the effects of Teflon-content and compaction pressure on the performance of electrodes made by shop production methods with the qualified catalyst. Four of the better running cells were operated for an extended period of time. See Table 2.2-1 for test results compared to the cell used for catalyst qualification (4387). The performance of Cells 4391 and 4404 were similar to the laboratory cell (4387) after approximately 3500 -hours of operation. Cell 4404 operated for over 6000 -hours before completing its test program. 


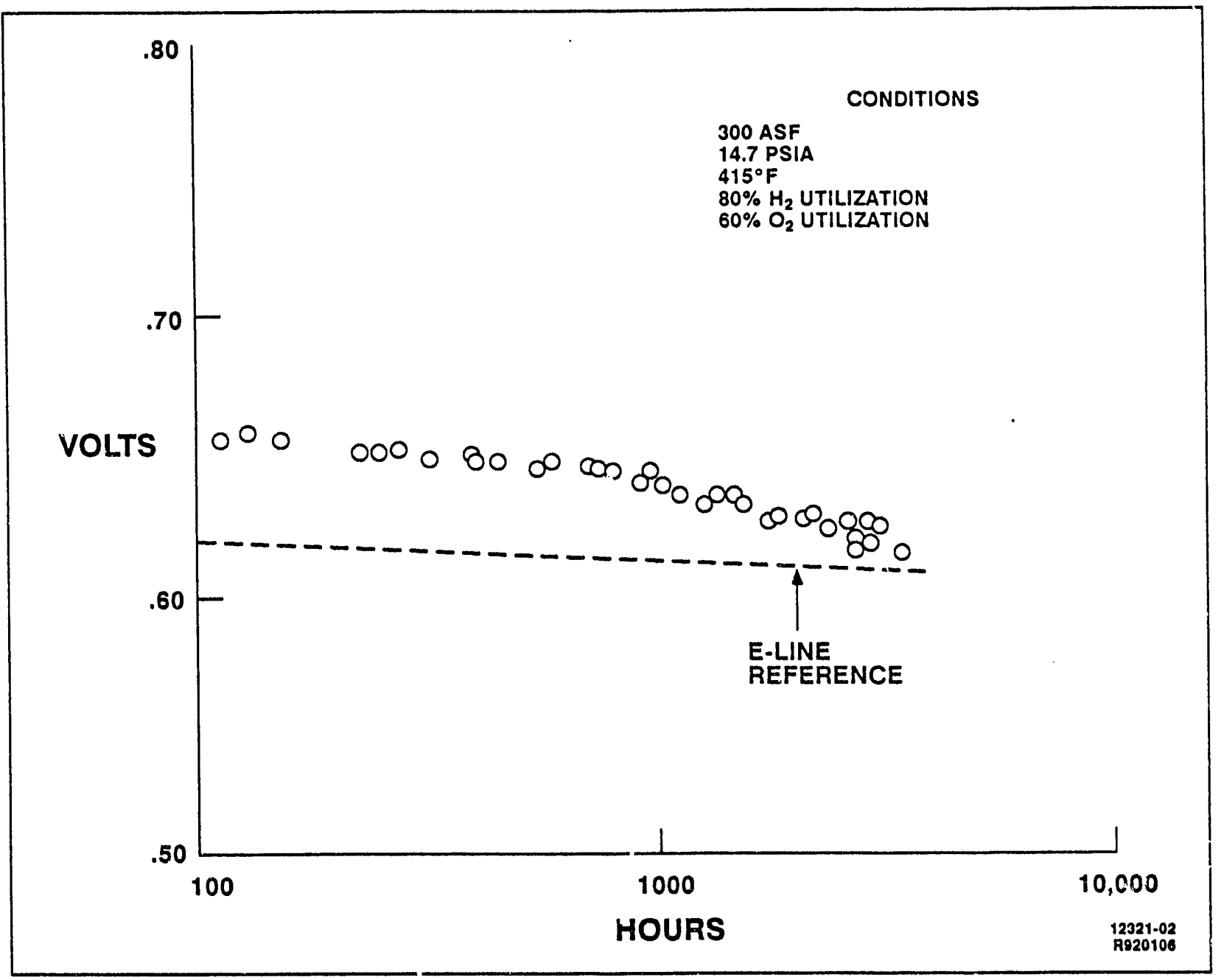

Figure 2.2-2. Performance History of Cell 4387

Table 2.2-1. GSB-18 Electrode Optimization Trials Performance at $300 \mathrm{ASF} / 415^{\circ} \mathrm{F} / 14.7 \mathrm{psia}$

\begin{tabular}{|ccccc|}
\hline Build No. & \multicolumn{2}{c|}{ At Approximately 3500-hours } & \multicolumn{2}{c|}{ Final } \\
& Hours & Volts & Hours & Volts \\
\hline & & & & \\
4390 & $\overline{3540}$ & 0.608 & 2386 & 0.584 \\
4401 & $\overline{3107}$ & $\overline{0.607}$ & 1937 & 0.604 \\
4404 & 3451 & 0.605 & 6074 & 0.560 \\
4387 & & 3451 & 0.605 \\
\hline
\end{tabular}

(3) GSB-18 Cell Tests on Optimized Electrodes

After establishing the catalysts for the short stack and using Teflon contents and compaction pressures selected based on optimization testing, four cells with these optimized selections were put on test to 
gain insight into the performance characteristics and effect of long term operation. Two of the cells used Vendor A substrates, and two were fabricated with substrates "formed for IFC." These cells were operated initially at the $300 \mathrm{ASF} / 415^{\circ} \mathrm{F}$ baseline condition to evaluate performance relative to the extensive IFC database. After verifying acceptable performance, conditions were changed to $225 \mathrm{ASF}$ and $400^{\circ} \mathrm{F}$ (Tabie 2.2-2) for endurance evaluations.

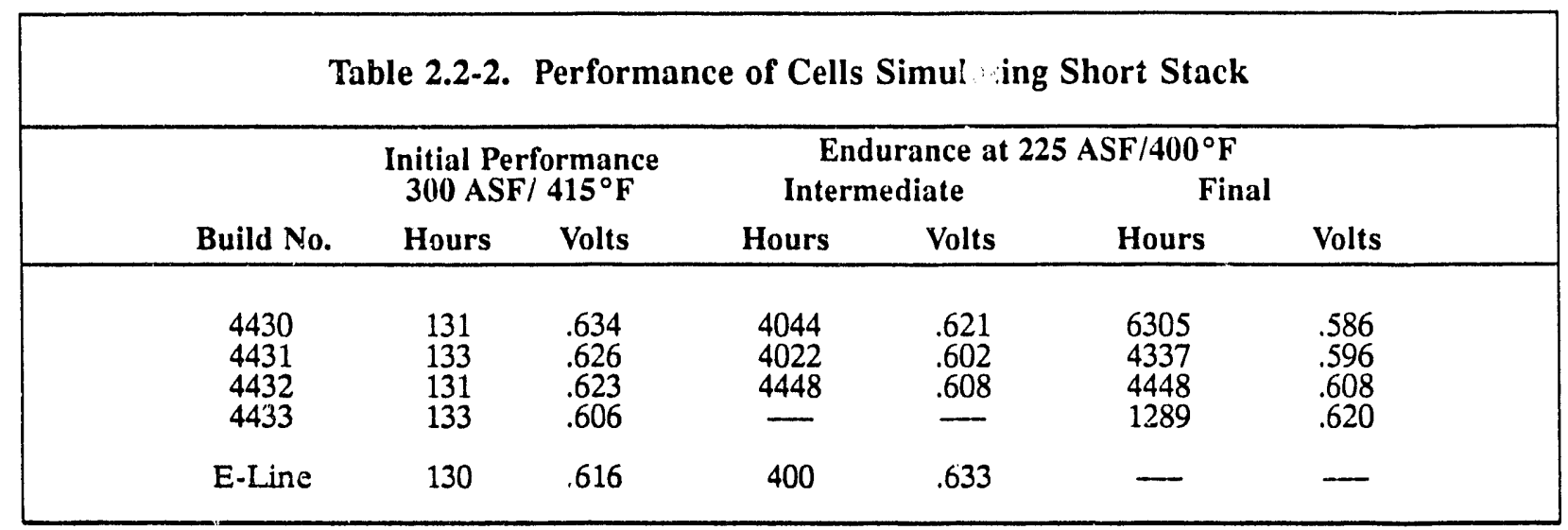

Four additional cells were fabricated similar to the fore-mentioned cells and brought to test to evaluate the effect of elevated temperature on endurance. As shown in Table 2.2-3, these cells were first evaluated at the atmospheric baseline condition of $300 \mathrm{ASF}$ at $415^{\circ} \mathrm{F}$ to confirm acceptable operation. Since the initial performance of these cells was similar to the baseline group in Table 2.2-2, the endurance evaluation was initiated by setting the test conditions to $225 \mathrm{ASF}$ and $425^{\circ} \mathrm{F}$.

\begin{tabular}{|c|c|c|c|c|c|c|}
\hline \multirow[b]{3}{*}{ Build No. } & \multirow{2}{*}{\multicolumn{2}{|c|}{$\begin{array}{l}\text { Initial Performance } \\
300 \mathrm{ASF} / 415^{\circ} \mathrm{F}\end{array}$}} & \multicolumn{3}{|c|}{ Endurance at $225 \mathrm{ASF} / 425^{\circ} \mathrm{F}$} & \\
\hline & & & Inte & iate & & \\
\hline & Hours & Volts & Hours & Volts & Hours & \\
\hline $\begin{array}{l}4448 \\
4450 \\
4451 \\
4457\end{array}$ & $\begin{array}{l}128 \\
117 \\
135 \\
133\end{array}$ & $\begin{array}{l}.595 \\
.639 \\
.624 \\
.591\end{array}$ & $\begin{array}{l}1233 \\
1210 \\
1191 \\
1021\end{array}$ & $\begin{array}{l}.627 \\
.650 \\
.651 \\
.630\end{array}$ & $\begin{array}{l}1233 \\
6573 \\
3690 \\
1021\end{array}$ & $\begin{array}{l}.627 \\
.583 \\
.622 \\
.630\end{array}$ \\
\hline
\end{tabular}

As expected, the performance of the elevated temperature cells was higher than the baseline $400^{\circ} \mathrm{F}$ cells at the beginning of the endurance evaluation, but the $425^{\circ} \mathrm{F}$ cells decayed at a higher rate. A graphic comparison is presented in Figure 2.2-3, and final performance levels of the $425^{\circ} \mathrm{F}$ cells were similar to the $400^{\circ} \mathrm{F}$ cells.

A subscale cell (build 6654) containing optimized short stack electrodes was also started for the purpose of demonstrating operation at 120 psia and $400^{\circ} \mathrm{F}$. Initial cell voltage at $200 \mathrm{ASF}$ was 0.790 volts. This was $10 \mathrm{mV}$ higher than typical Configuration "A" 2-inch by 2 -inch cells under similar conditions. Initial performance at 300 ASF was 0.758 volts while after 1863 hours performance was 0.741 volts. Testing was concluded at 3327 hours with a final voltage of 0.698 . 


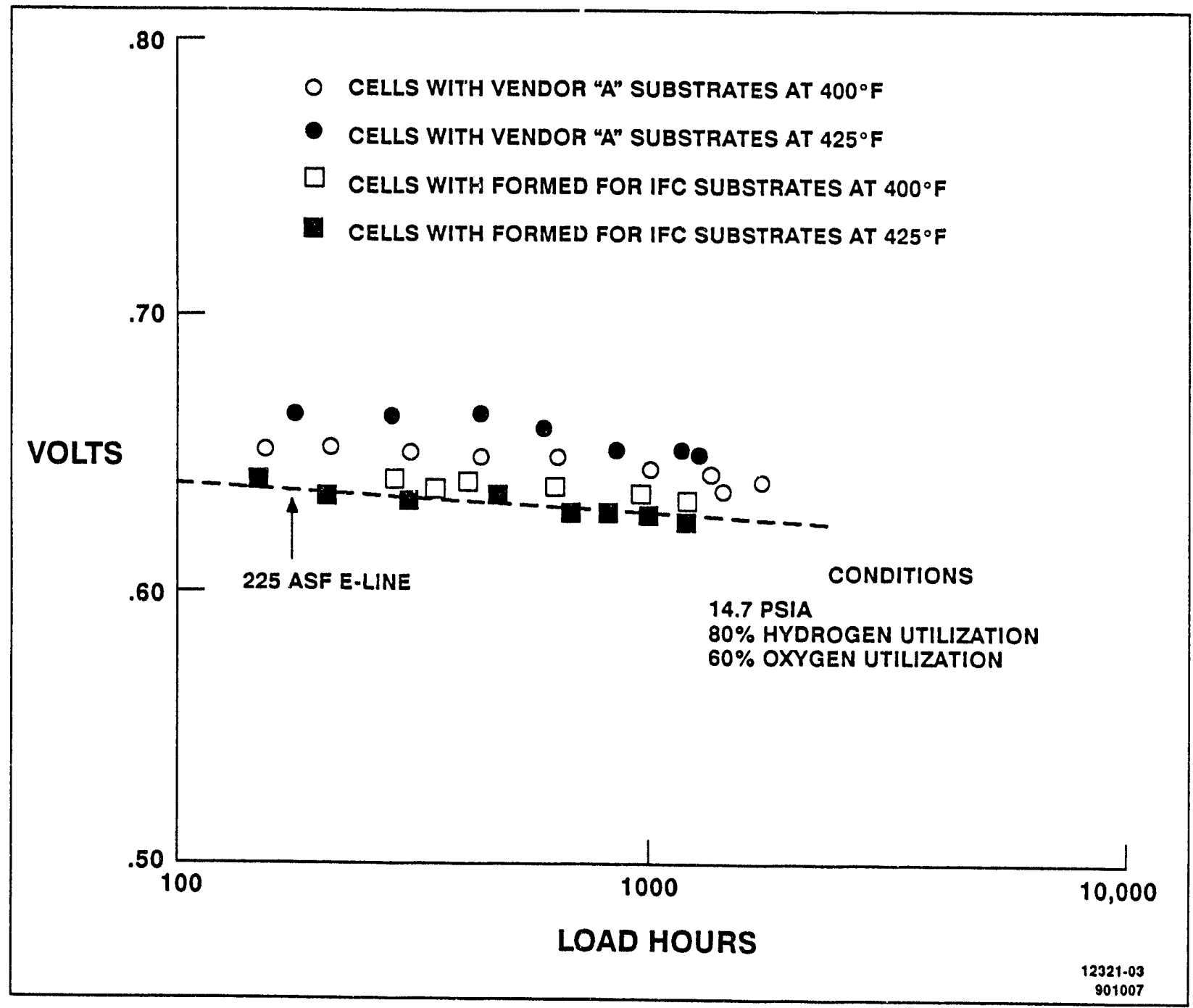

Figure 2.2-3. Impact of Elevated Temperature

Prior to the initial operation of the small area development stack, two cells (builds 4473 and 4483 cut from full-sized short stack electrodes) went to test to track the short stack. Build 4473 had Vendor A substrates while build 4483 had suıstrates "formed for IFC." Both cells operated at 225 ASF and $400^{\circ} \mathrm{F}$. Results of testing are summarized in Table 2.2-4 and compared to actual short stack performance in Figure 2.2-4.

Table 2.2-4. Performance of Cell Tracking the Small Area Development Stack 14.7 PSIA/225 ASF/400F

\begin{tabular}{|ccccc|}
\hline & \multicolumn{2}{c}{ Initial } & \multicolumn{2}{c|}{ Final } \\
Build No. & Hours & Volts & Hours & Volts \\
\hline & & & & \\
4473 & 76 & 0.664 & 6237 & 0.612 \\
4483 & 184 & 0.649 & 2302 & 0.629 \\
& & & & \\
\hline
\end{tabular}




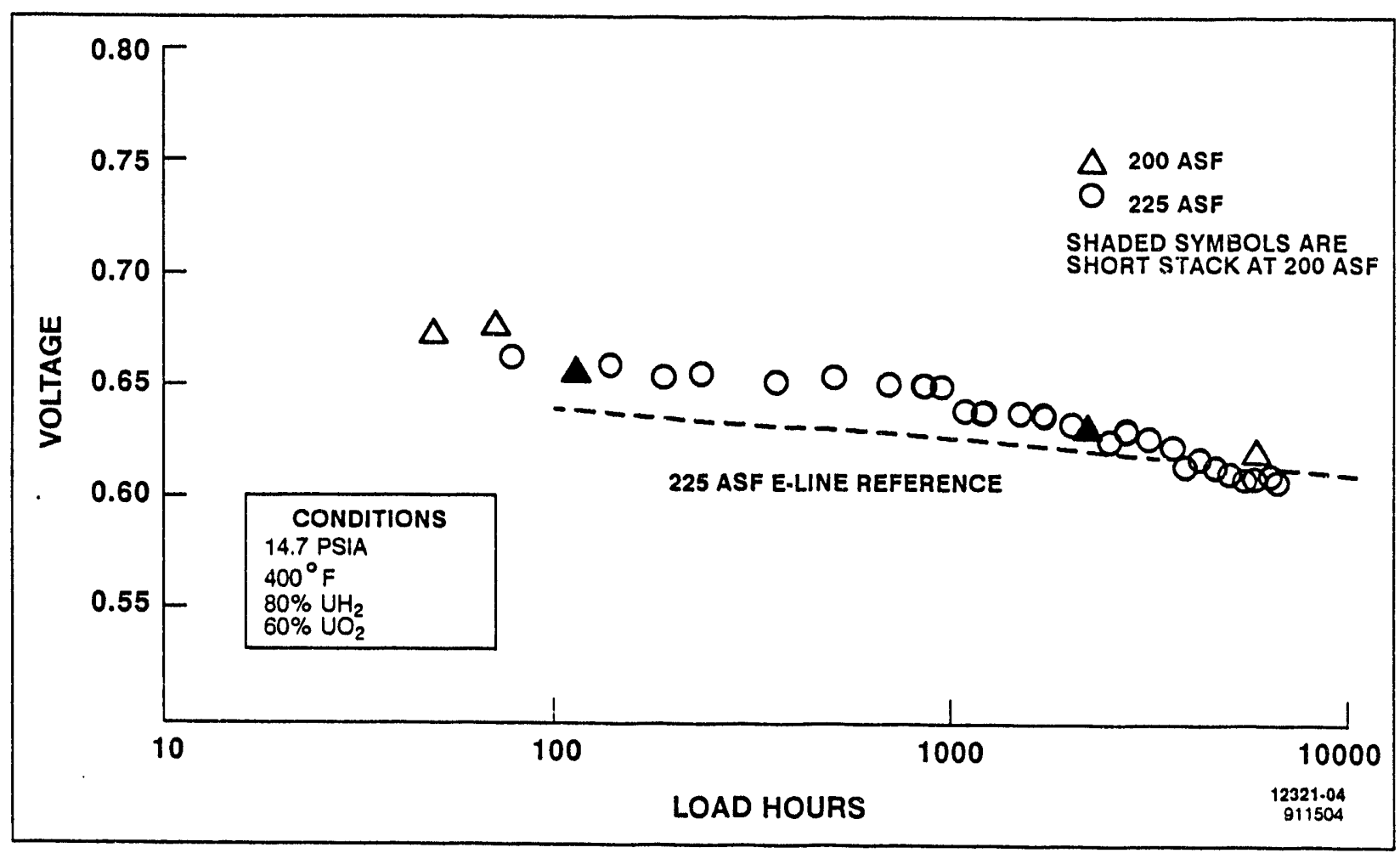

Figure 2.2-4. Subscale Cell 4473 Tracking the Small Area Development Stack

Two cells (builds 6681 and 6702), constructed like cell 4473, were operated at 120 psia and $400^{\circ} \mathrm{F}$ to track pressurized operation of the short stack. Both cells were operated satisfactorily up to 300 ASF. See Table 2.2-5.

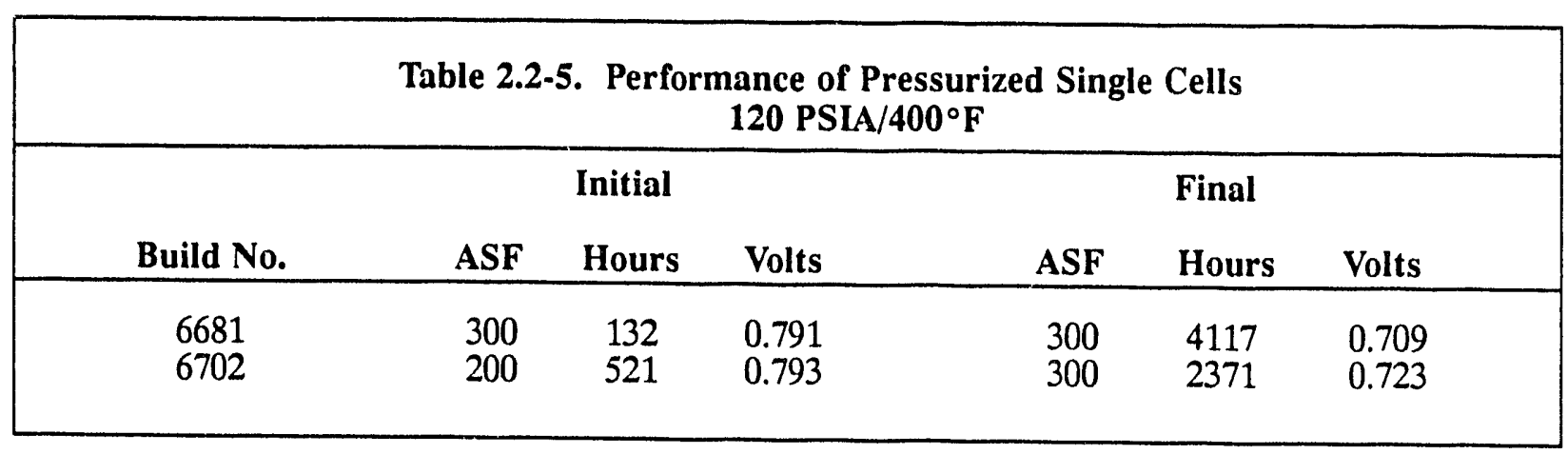

(4) Evaluation of Cells with GSB-18P Catalyst

Most of the testing of GSB-18P cathode catalyst in subscale cells was performed in 1986 under previous contract (DEN3-364 - Task Order No. 4 - Subscale Cell Technology). Several Configuration-B cells were operated at a variety of conditions, including periods at $300 \mathrm{ASF}$ and $120 \mathrm{psia}$. The cathodes in all of these cells contained GSB-18P catalyst which had been prepared and made into electrodes on an experimental substrate in IFC laboratories. Laboratory methods were also used to deposit the thin matrices which were evaluated in the same program. The data from those cells show clearly that power densities in excess of $200 \mathrm{WSF}$ are attainable, at 120 psia, from subscale cells incorporating laboratorymade catalysts, electrodes and matrices. 
At the beginning of this program, a production-size batch of GSB-18P catalyst was made into electrodes using shop production methods. Testing of three subscale Configuration-B cells (No. 6499, 6500 and 6501) with GSB-18P cathode catalyst was initiated. The initial performance of all three cells was low and did not impiuve as expected during break-in at ambient pressure conditions. Five additional cells were started for ambient pressure testing, and three were started for 120 psia.

The five ambient cells (builds $4439,4441,4446,4447$ and 4456) with production electrodes were operated at the short stack rated power conditions of $225 \mathrm{ASF}, 400^{\circ} \mathrm{F}$ and 14.7 psia to evoluate production fabrication methods as well as the decay characteristics of this cathode catalyst and loading (See Table 2.2-6). None of these five cells achieved the level of performance demonstrated by cells in the previous program.

\begin{tabular}{|c|c|c|c|c|c|c|}
\hline \multicolumn{7}{|c|}{$\begin{array}{l}\text { Table 2.2-6. Performance of Cell with GSB-18P Cathode Catalyst } \\
1 \mathrm{mg} / \mathrm{cm}^{2} \text { Catalyst Loading at Ambient Pressure }\end{array}$} \\
\hline \multirow[b]{3}{*}{ Build No. } & \multirow{2}{*}{\multicolumn{2}{|c|}{$\begin{array}{l}\text { Initial Performence } \\
300 \mathrm{ASF} / 415^{\circ} \mathrm{F}\end{array}$}} & \multicolumn{4}{|c|}{ Endurance at $225 \mathrm{ASF} / 400^{\circ} \mathrm{F}$} \\
\hline & & & \multicolumn{2}{|c|}{ Intermediate } & \multicolumn{2}{|c|}{ Final } \\
\hline & Hours & Volts & Hours & Volts & Hours & Volts \\
\hline 4394 & 131 & .670 & 2497 & .673 & 3372 & .670 \\
\hline $\begin{array}{l}4439 \\
4441 \\
4446 \\
4447 \\
4456\end{array}$ & $\begin{array}{r}122 \\
84 \\
85 \\
134 \\
130\end{array}$ & $\begin{array}{l}.661 \\
.661 \\
.632 \\
.652 \\
.608\end{array}$ & $\begin{array}{l}326 \\
193 \\
407 \\
384 \\
310\end{array}$ & $\begin{array}{l}.666 \\
.672 \\
.648 \\
.656 \\
.646\end{array}$ & $\begin{array}{r}1394 \\
1429 \\
1107 \\
1233 \\
887\end{array}$ & $\begin{array}{l}.648 \\
.660 \\
.644 \\
.627 \\
.650\end{array}$ \\
\hline
\end{tabular}

The three cells (Table 2.2-7) put on test for the purpose of running under pressurized conditions of 120 psia were run initially at the baseline ambient conditions $\left(300 \mathrm{ASF} / 415^{\circ} \mathrm{F}\right)$ to verify cell performance acceptability. These cells like their ambient counterparts, did not achieve performance levels demonstrated in this previous program. The cells were brought to 120 psia at the pressurized baseline conditions $\left(300 \mathrm{ASF} / 400^{\circ} \mathrm{F}\right)$ and exhibited performance below expectations.

\begin{tabular}{|c|c|c|c|c|c|c|}
\hline \multirow[b]{2}{*}{ Build No. } & \multicolumn{2}{|c|}{$\begin{array}{c}14.7 \text { psia } \\
300 \mathrm{ASF} / 415^{\circ} \mathrm{F}\end{array}$} & \multicolumn{4}{|c|}{$\begin{array}{c}120 \mathrm{psia} \\
225 \mathrm{ASF} / 400^{\circ} \mathrm{F}\end{array}$} \\
\hline & Hours & Volts & Hours & Volts & Hours & Volts \\
\hline $\begin{array}{l}6660 \\
6661 \\
6662\end{array}$ & $\begin{array}{r}72 \\
144 \\
69\end{array}$ & $\begin{array}{l}.636 \\
.626 \\
.644\end{array}$ & $\begin{array}{l}546 \\
478 \\
400\end{array}$ & $\begin{array}{l}.754 \\
.752 \\
.751\end{array}$ & $\begin{array}{r}1050 \\
980 \\
904\end{array}$ & $\begin{array}{l}.740 \\
.737 \\
.732\end{array}$ \\
\hline
\end{tabular}

Cell 4394 was fabricated in the laboratory using $1 \mathrm{mg} / \mathrm{cm}^{2}$ GSB-18P catalyst from the production-size batch. The cell was operated at ambient pressure. As indicated in Table 2.2-6 and Figure 2.2-5, performance of this cell was very good throughout testing. This result indicated that the production-size batch met requirements and that the performance problem was associated with the shop process for 
electrode manufacture. The development effort for GSB-18P electrode fabrication was performed in a complimenting program (DE-AC2-83FE60338).

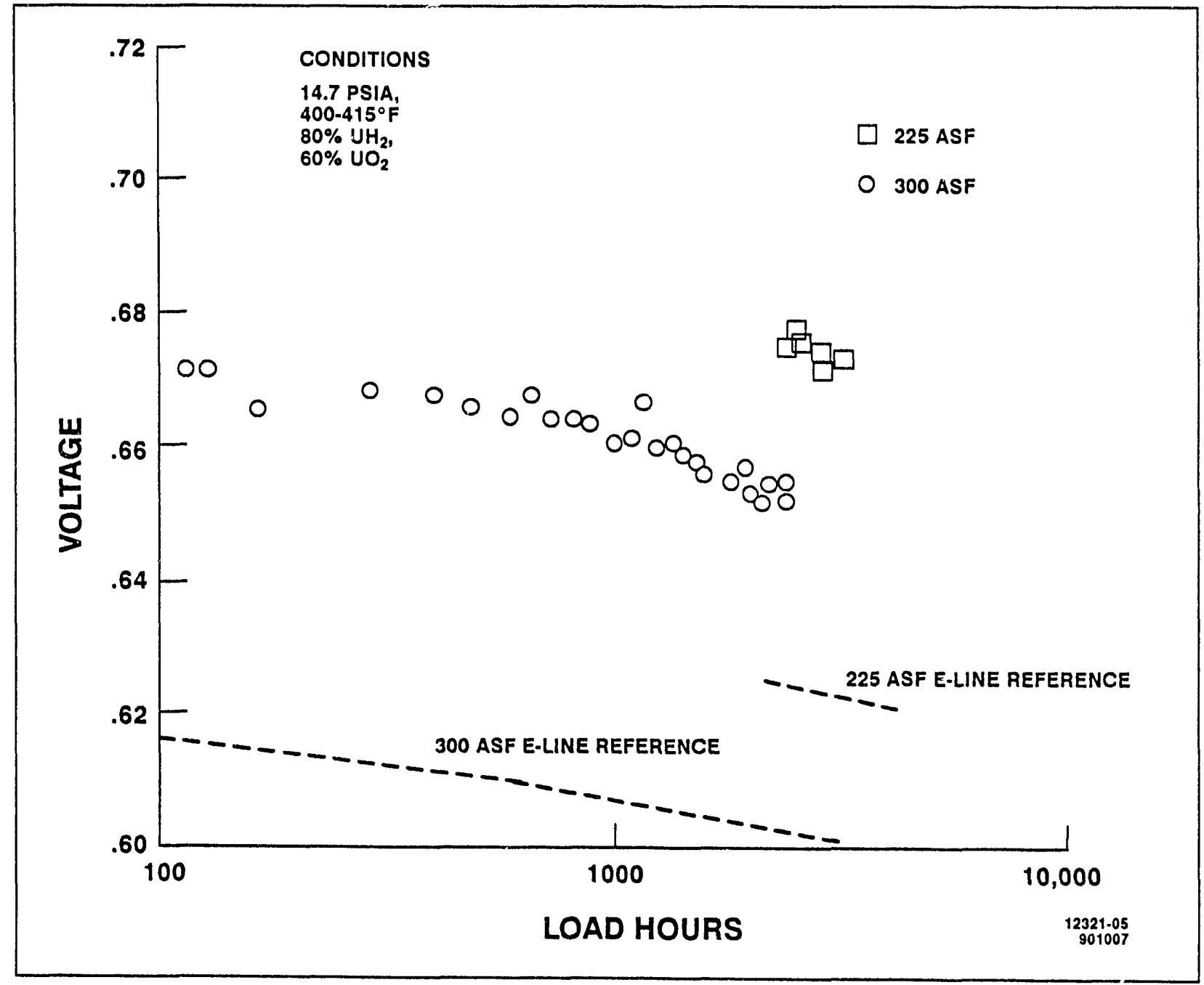

Figure 2.2-5. Cell 4394 with $1 \mathrm{mg} / \mathrm{cm}^{2}$ Loading of GSB-18P

Following successful development of GSB-18 shop electrode process, five subscale cells were built with new production GSB-18P catalyst. Performance durability of the five cells (builds 6751, 6752, 6753, 6754, and 6769) at pressurized conditions is shown in Figure 2.2-6. A sixth cell (build 6763), fabricated similar to the above cells but with a laminated anode ERP, stayed on test to evaluate its performance and stability relative to the other cells. Like several of the other cells, performance has been obtained up to $600 \mathrm{ASF}$ (Figure 2.2-7), Four of these cells were selected for extended testing to judge the durability of these at pressurized operating conditions. Results of these tests are listed in Table 2.2-8, and the performance durability of Cells 6751 and 6763 are shown in Figures 2.2-8 and 2.2-9, respectively. 


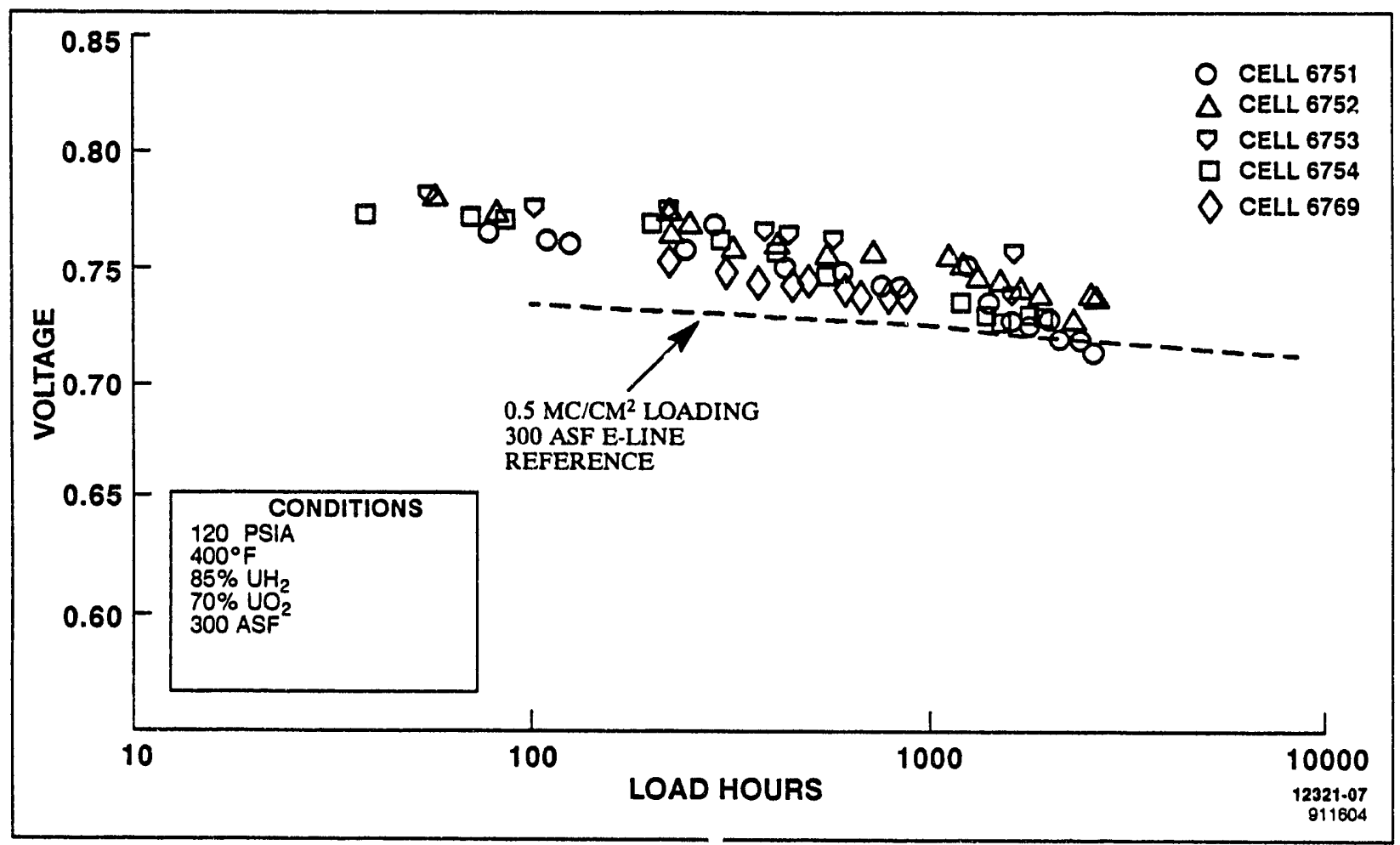

Figure 2.2-6. GSB-18P Cathode Catalyst

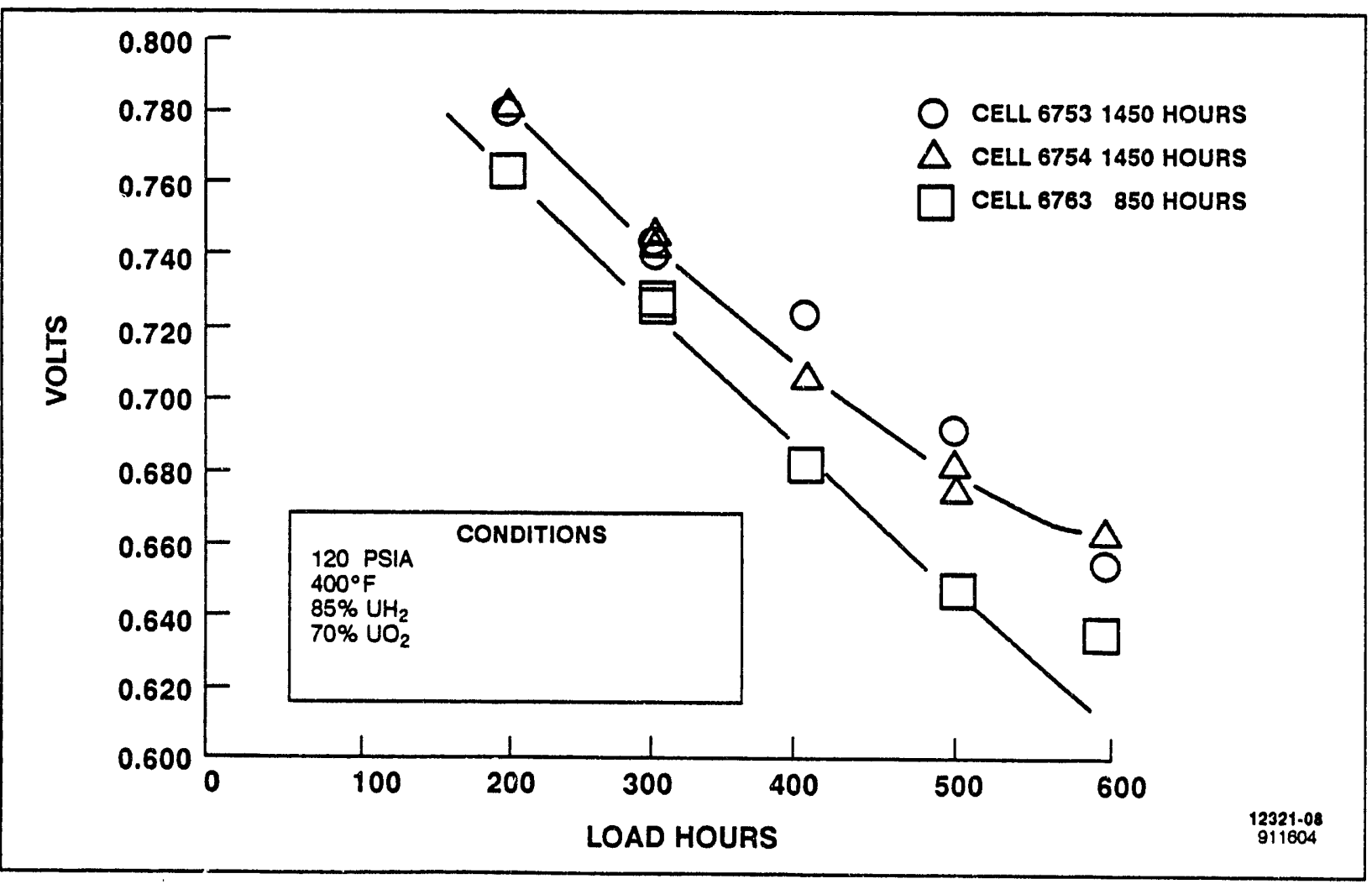

Figure 2.2-7. High Current Density Evaluations 
Table 2.2-8.

Performance of Pressurized GSB-18P Single Cells $120 \mathrm{PSIA} / 300 \mathrm{ASF} / 400^{\circ} \mathrm{F}$

\begin{tabular}{|ccccc|}
\hline & \multicolumn{3}{c}{ Initial Performance } & \multicolumn{2}{c|}{ Final Performance } \\
Build No. & Hours & Volts & Hours & Volts \\
\hline 6751 & 79 & .764 & 5452 & .704 \\
6752 & 59 & .779 & 3279 & .696 \\
6763 & 120 & .760 & 4812 & .697 \\
6769 & 227 & .751 & 3658 & .687 \\
& & & & \\
\hline
\end{tabular}

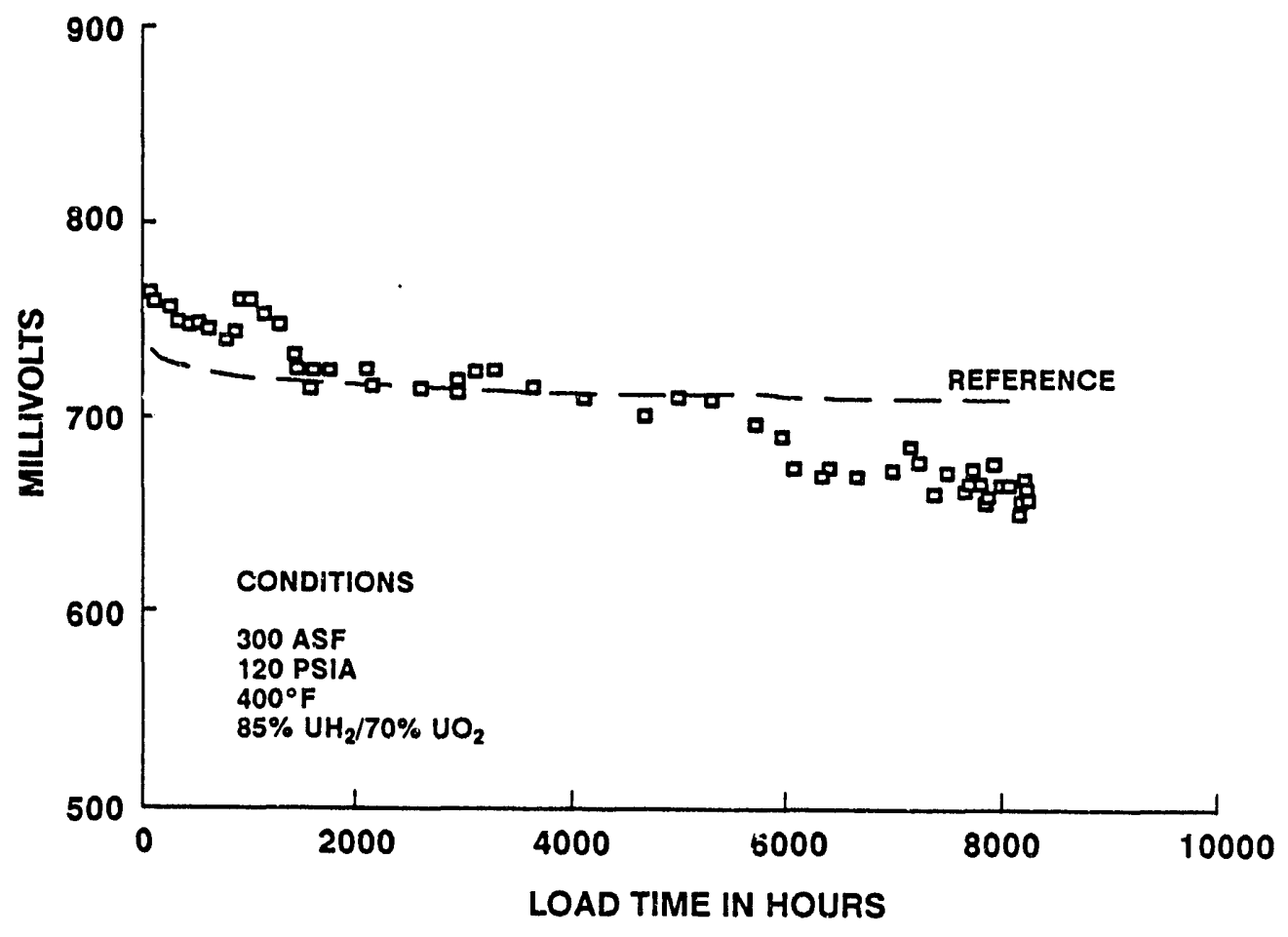

Figure 2.2-8. Performance History of Build 6751 GSB-18P Catalyst 


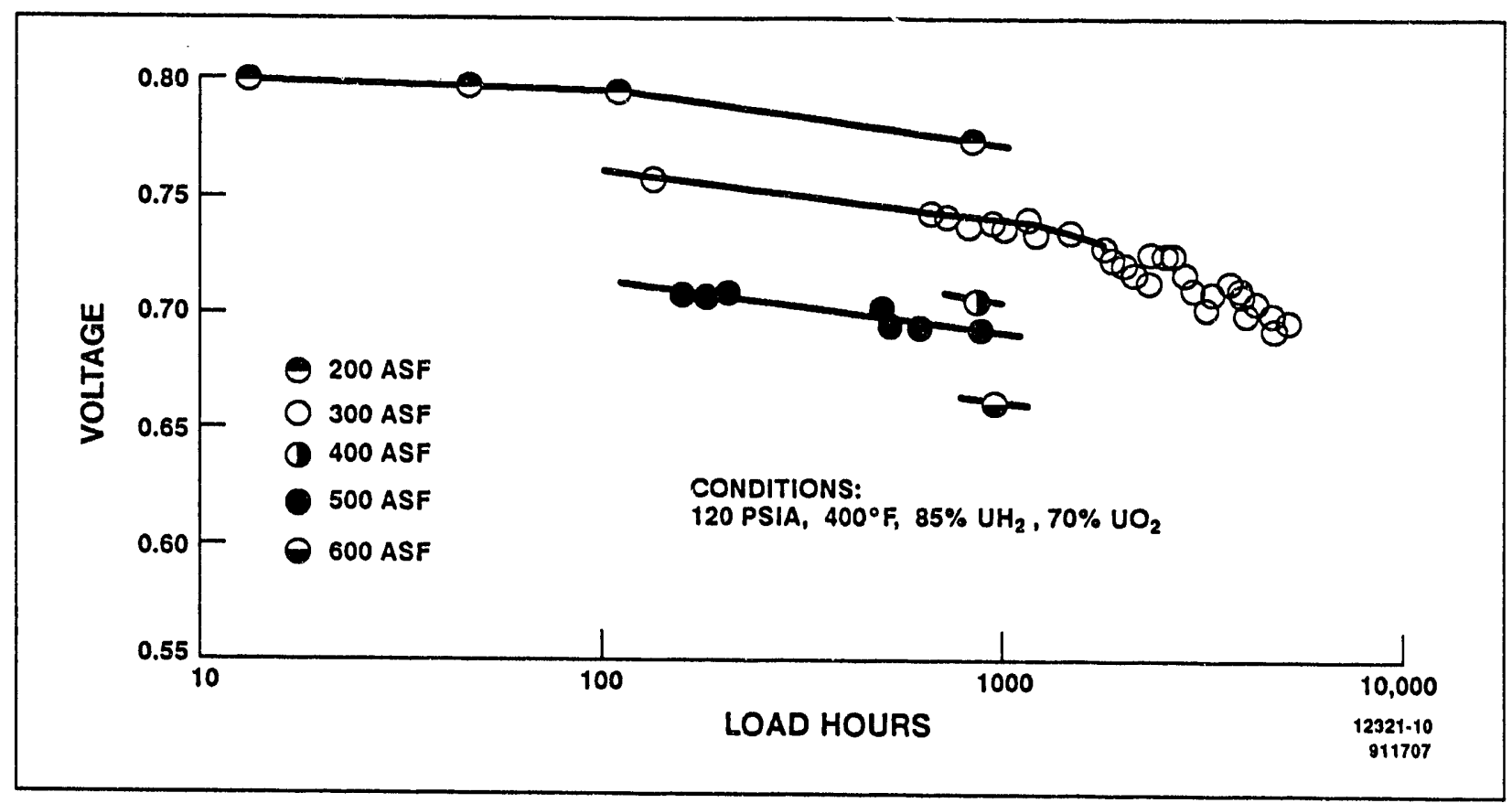

Figure 2.2-9. GSB-18P Cathode Catalyst Cell 6763

In order to track the operation of the first $10-\mathrm{ft}^{2}$ short stack, five cells (builds $6774,6775,6776,6777$, and 6781) started test. Each subscale cell is fabricated like one of the five substacks in the $10-\mathrm{ft}^{2}$ short stack. The five pressurized cells were operated at $300 \mathrm{ASF}$ and $400^{\circ} \mathrm{F}$. See Table 2.2.9 and Figure 2.2-10.

Table 2.2-9. GSB-18P Subscale Cells Tracking the 10- $\mathrm{ft}^{2}$ Short Stack 120 PSIA $/ 400^{\circ} \mathrm{F} / 300$ ASF

\begin{tabular}{|cccccc|}
\hline & $\begin{array}{c}\text { Equivalent } \\
\text { Short Stack } \\
\text { Substack }\end{array}$ & \multicolumn{2}{c}{ Initial Performance } & \multicolumn{2}{c|}{ Final Performance } \\
Build No. & Hours & Volts & Hours & Volts \\
\hline 6774 & No. 1 & 156 & 0.772 & 6117 & 0.681 \\
6775 & No. 2 & 155 & 0.755 & 3713 & 0.692 \\
6776 & No. 3 & 132 & 0.735 & 2170 & 0.669 \\
6777 & No. 4 & 109 & 0.761 & 3667 & 0.695 \\
6781 & No. 5 & 64 & 0.767 & 3111 & 0.681 \\
& & & & & \\
\hline
\end{tabular}




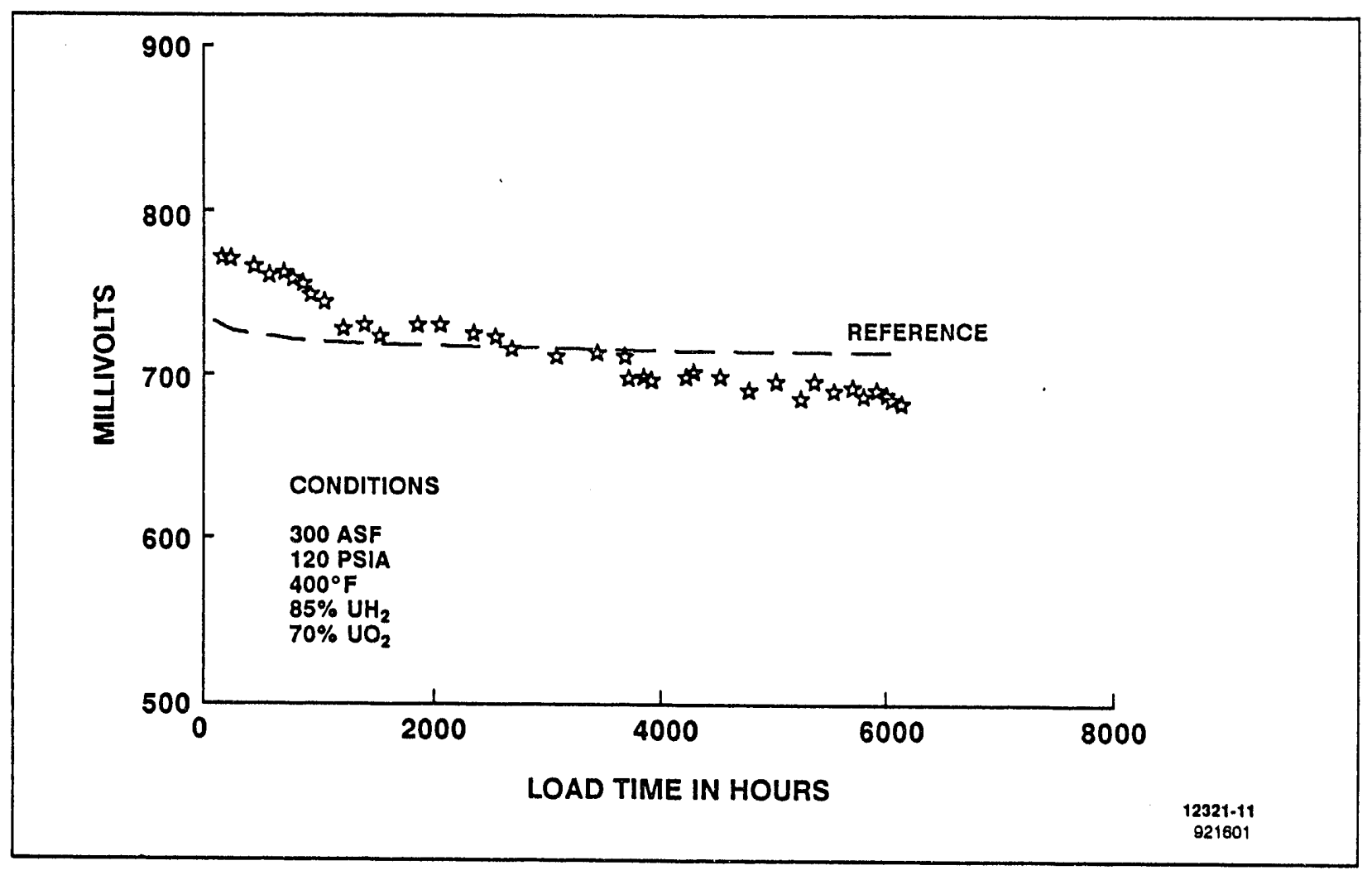

Figure 2.2-10. Performance History of Build 6774 GSB-18P Catalyst

(5) Tolerance to Off-Design Operation

Two cells (build 6490 and 6491) containing standard on-site cell components were tested to evaluate the impact of reactant cross-pressure. At approximately 1000 hours, the cells were exposed to a crosspressure "stress test." Starting from balanced anode and cathode pressures, a pressure imbalance was created and increased in steps to 15 psi. As shown in Figures 2.2-11 and 2.2-12. The performance of both cells was unchanged after restoring baseline conditions.

Cells $4338,4339,4340$, and 4341 contain electrodes with an alternative substrate (Vendor A). The response of the cells to electrolyte additions was investigated by increasing electrolyte fill of ERP's to 50-60 percent. The two cells (4340 and 4341) in which the cathode ERP's were wetproofed exhibited much greater overall losses than standard cells (4338 and 4339). These losses were mainly due to increased oxygen gains. 


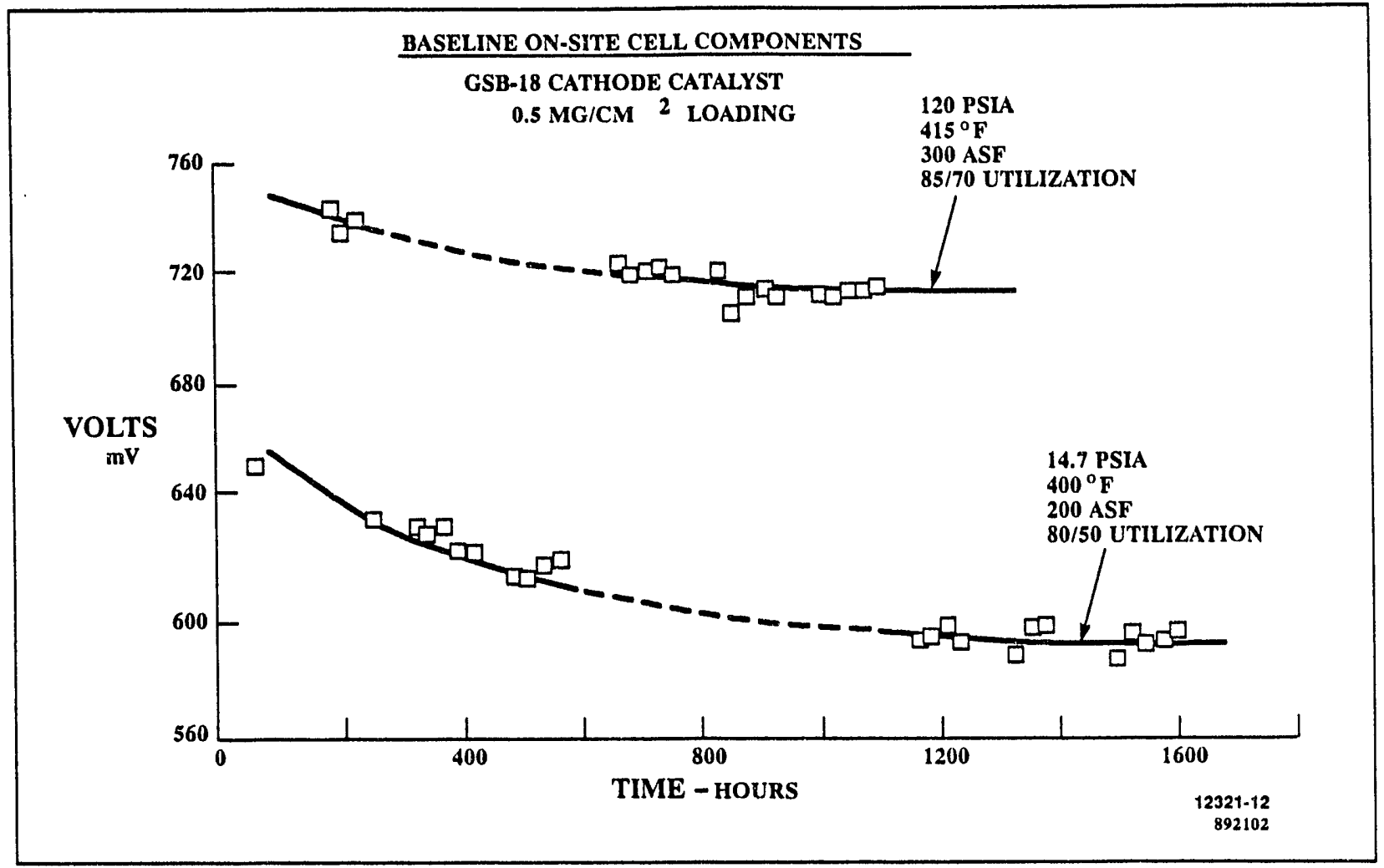

Figure 2.2-11. Performance History Cell No. 6490

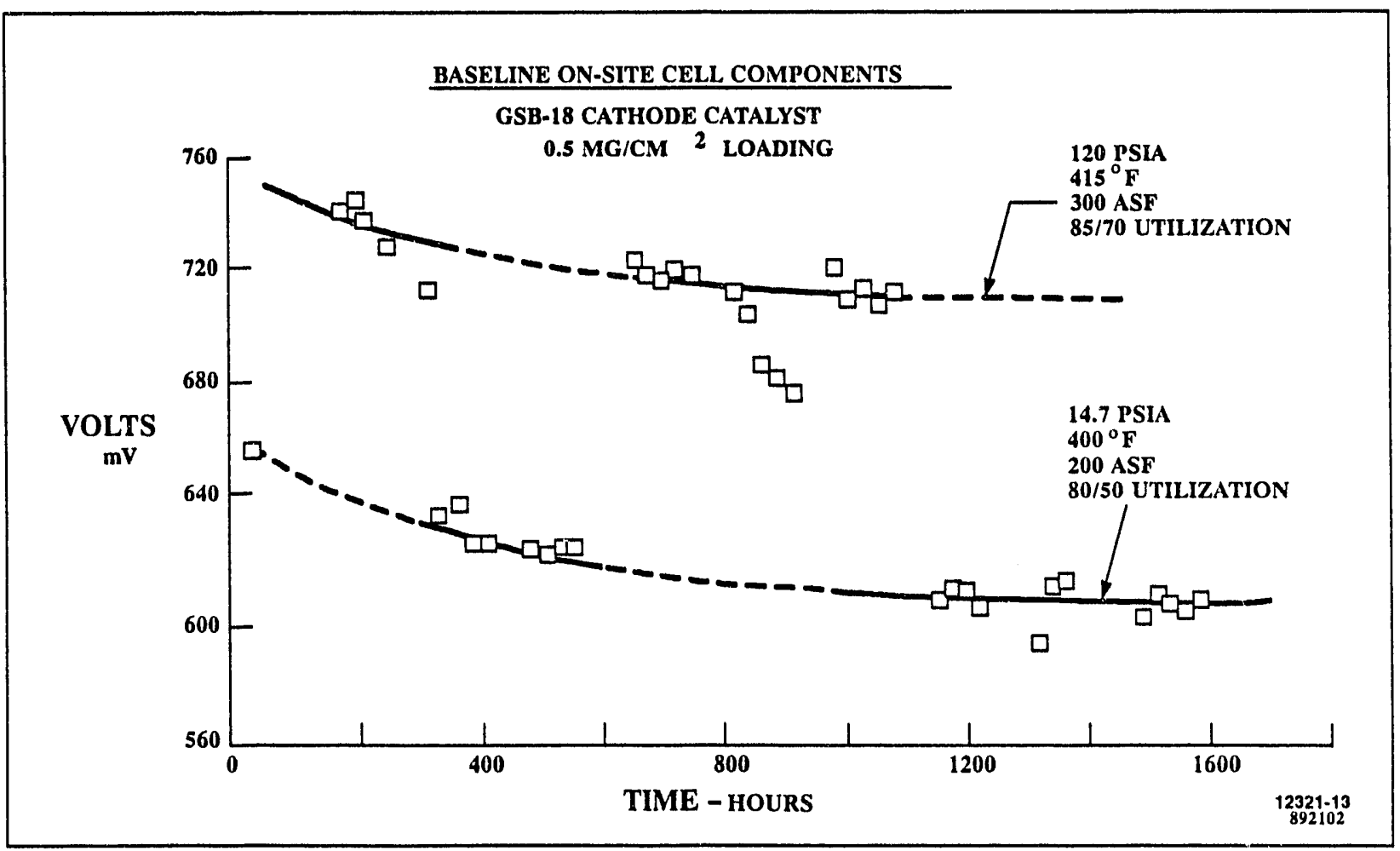

Figure 2.2-12. Performance History Cell No. 6491 
(6) Improved Catalyst Layers

Cell tests of new improved catalyst layers were performed. A test program which stressed the functional capabilities of both anodes and cathodes was followed. This program was directed towards identifying both anode and cathode catalyst layers which have improved electrolyte management properties. The development of these new catalyst layers would allow higher cell efficiencies at power densities of 200 WSF or greater. Each cell test followed the identical program so that direct comparisons of performance could be made between electrodes with different hydrophobicities. Programs consisted of break-in at 60-300 ASF; diagnostics and performance to $500 \mathrm{ASF}$; and shutdown and electrolyte conditioning (wet-up) cycles.

The results of the subscale cells tested indicate that the new improved electrodes allow better acid management within the cell package and, therefore, improved high current density performance. The anodes are very stable, and some of the new cathode structures have stability at least comparable to the standard cathodes. Continued cell development and scale-up of the catalyst deposition approach for production are however required before demonstration in full-size cells.

(7) High Pressure Evaluation

Cell 6740 was built to evaluate operation at elevated pressure. Results are shown in Figure 2.2-13. Although performance at 120 psia was typical of other $1 \mathrm{mg} / \mathrm{cm}^{2} \mathrm{GSB}-18 \mathrm{P}$ cells, performance at 255 psia and 400 psia fell short of expectations. It is not clear whether crossover through the thin matrix or problems with the single cell test hardware caused the short fall.

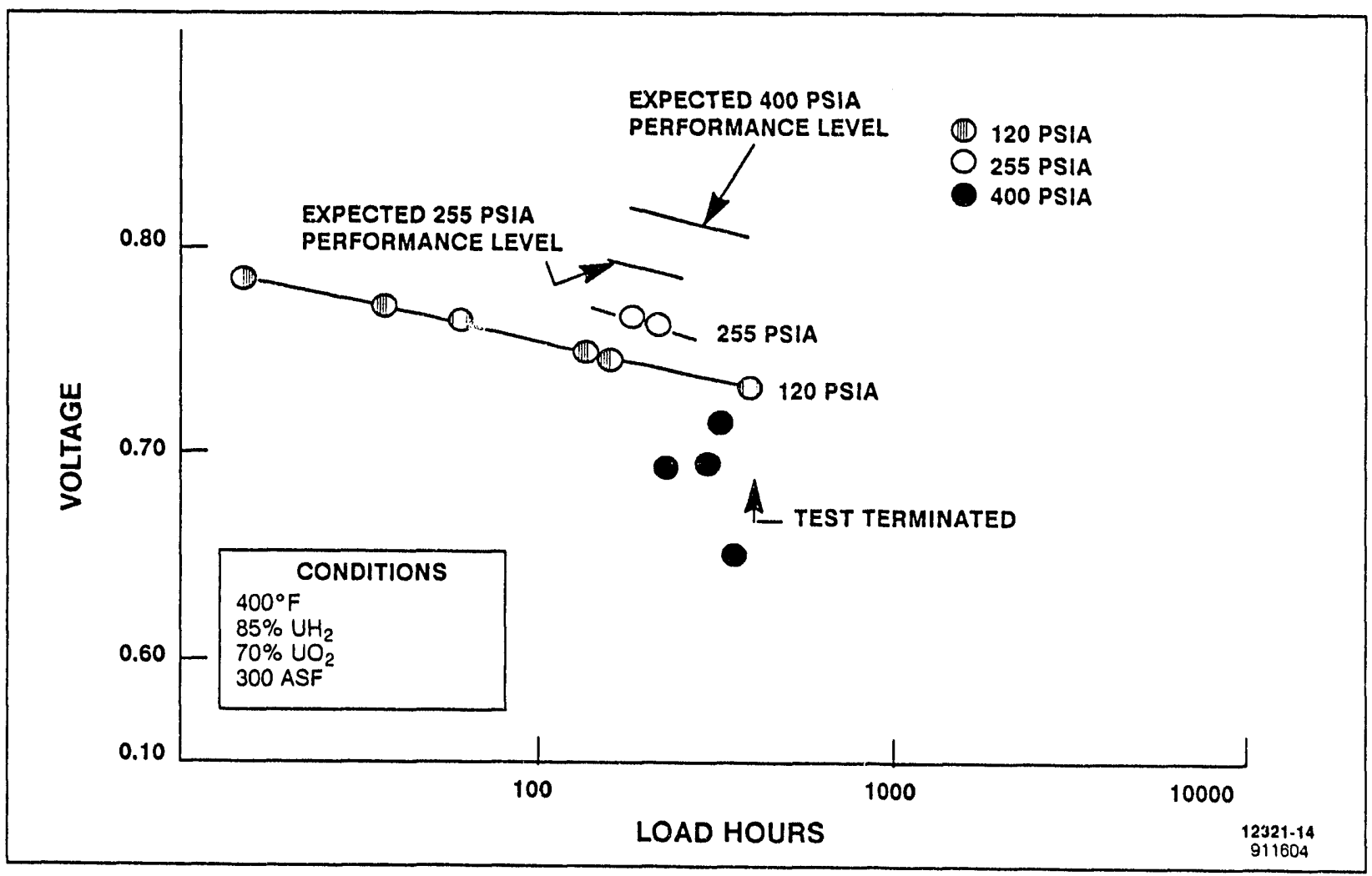

Figure 2.2-13. GSB-18P Catalyst At High Pressure Cell 6770 


\section{TASK 3 - PROCESS DEVELOPMENT}

\section{Subtask 3.1 - Substrates}

\section{Objectives}

The objectives of this subtask are to develop the process technologies required to produce the substrates and electrolyte reservoir plates that meet the technical requirements and cost objectives established in the conceptual design.

\section{Summary}

Processing improvements for thin substrates and electrolyte reservoir plates were evaluated. According to material property measurements in Subtask 2.1, materials produced by the new processes are acceptable for use in cells operating at either ambient or pressurized conditions.

\section{Discussion of Activities}

Thin substrate handsheets were prepared using several forming options. Following characterization of the various handsheet in Subtask 2.1, target values of density and thickness were selected for a fullsize thin substrate precursor trial. After completing forming, one hundred full-size substrate precursors were given an experimental heat treatment which carbonized and graphitized them in one step. The heat treated sheets were wrinkled, presumably due to insufficient pressure on them. During the next heat treat attempt, a second one hundred full-size substrate precursors were also heat treated in a one-step process. Improvements were attempted by putting only one-half as many sheets between each heat treat spacer and locating the parts at the bottom of the entire heat treat load thus increasing the compressive load on the parts. These improvements resulted in essentially 100 percent of the substrate precursors surviving heat treat with satisfactory flatness. Samples of these heat treated substrates are compared to Vendor A substrates for density, thickness, and through-plane pressure drop in Figure 3.1-1.

Electrolyte reservoir plates (ERP's) were formed and also heat treated in the one-step process rather than the usual two-step process. As discussed in Subtask 2.1, material properties of these materials met specification. The simpler, lower cost process was therefore found acceptable for heat treating ERP's. 


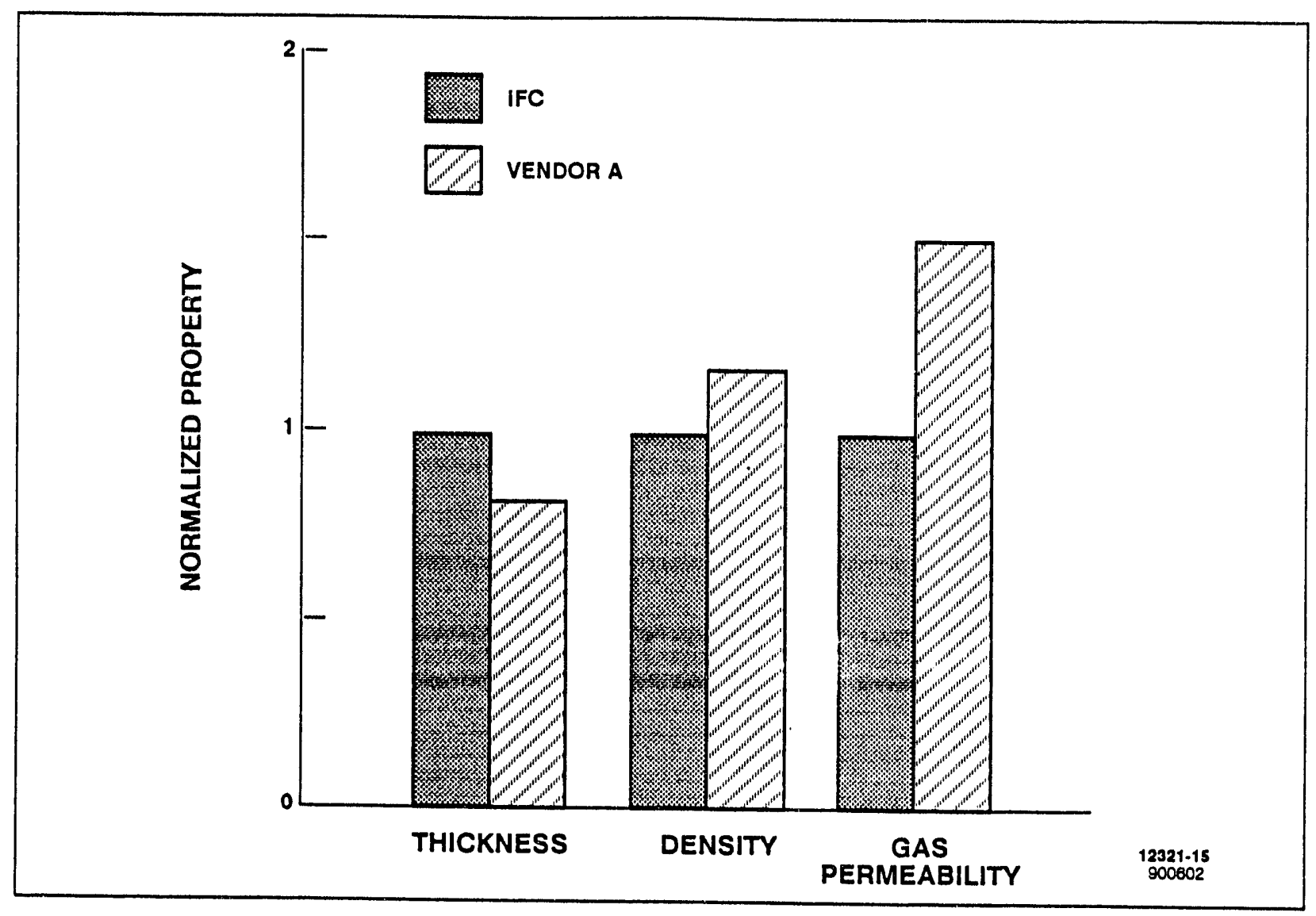

Figure 3.1-1. Properties Comparison Vendor A vs. IFC Substrate 


\section{Subtask 3.2 - Integral Separator}

\section{Objective}

The objective of this subtask is to develop the process technology to fabricate integral separators, up to $10-\mathrm{ft}^{2}$ in size, that meet the technical requirements and cost objectives established in the conceptual design.

\section{Summary}

Three (3) candidate integral separator configurations were defined for testing in the small area development stack. The enhanced graphite separators were found to be technically superior to the other two candidates, and were used in the remaining two stacks tested in the program and the conceptual design.

\section{Discussion of Activities}

A series of screening tests were developed for evaluating Integral Separator Plates (ISP's) removed from stack and rigs which have operating times up to 2600 hours. These tests measured sample electrical resistance, gas permeability, gas diffusivity, fluorescent dye penetration and electrochemical acid pumping. The results of the tests confirmed that the used ISP's showed evidence of electrolyte transfer between adjacent cells.

Based on the data cited above, scaleup of the original ISP's was suspended, and a subscale laboratory program was initiated to fabricate new alternate design ISP's. Approximately 400 samples were fabricated and evaluated. The samples were aged in ovens at simulated cell stack operating conditions and periodically removed for evaluation by the testing described above. This activity enabled the selection of the following three (3) ISP configurations for further cell stack evaluation:

1. An improved skived film separator utilizing a 50\% thicker composite sheet.

2. A multilayer design using two composite sheets separated by a fibrous reinforcernent structure.

3. Enhanced graphite separators.

Approaches 1 and 2 utilize higher purity graphite for improved corrosion resistance, and all three incorporate features to prevent acid transfer around the edge of the part.

Full-size samples were fabricated to demonstrate scaleup; no problems were encountered, and the shop process was modified to enable fabricating the three (3) candidate designs for actual testing in the small area development stack. Post-test evaluation of ISP's used in the small area development stack indicated that the enhanced graphite separators were technically superior to the other configurations, and this configuration was utilized in the $10-\mathrm{ft}^{2}$ subscale stack and the on-site small area stack and adopted in the conceptual design. 


\section{Subtask 3.3 - Seals and Matrix}

\section{Objectives}

The objective of this subtask is to develop the technology to fabricate higher integrity seals and matrices that meet the technical requirements and cost objectives established in the conceptual design.

\section{Summary}

Efforts focused on the development of thin matrices for pressurized operation and high integrity seals and fillerbands.

\section{Discussion of Activities}

(1) Bubble Pressure Tesiing

A bubble pressure test fixture was fabricated and assembled. Checkout was completed using on-site cell packages. The test fixture features a variable loading system to simulate a range of axial loads.

Bubble pressure tests of on-site cell packages were performed to determine baseline data. Several samples were cut from each region to assess variability. The bubble pressure of each 3-inch by 3-inch cutout from full-size electrodes is shown at the location samples in Table 3.3-1.

A test fixture to measure edge seal leakage was designed and fabricated. The fixture was used to differentiate between through-the-seal and interfacial leakage. 
Table 3.3-1. Bubble Pressure Results

Full-Size On-Site Cells

2 Pairs Tested

Active Area

Sample

Number

1

2

3

4

5

6

7

8

9

10

11

12

13

14

15

16

17
Inlet/Outlet Zones

Bubble

Pressure

$\sim$ PSI

48

16

34

32

5

46

39

18

17

18

22

6

21

9

13

6

11

\section{Interface Seal Zone}

\section{Sample}

Number

Bubble

Pressure

1

$\sim$ PSI

2

4

3

2

4

0 (able

Pressure

2

3

3

6

11




\section{(2) Fillerband Development}

The possibility of forming edge seals, fillerband and matrix simultaneously was pursued. The baseline fillerband was measured to have bubble pressure of 2-3 psid with a thin matrix applied. Although subscale results of the current effort produced up to 14-15 psid, forming lead to mud-cracking and poor reliability. The effort was, therefore, discontinued.

The application of the fillerband with a curtain coater was next investigated. The result was a defect free layer. A matrix coated fillerband sample was measured to have 14 psid bubble pressure with 50 psi compressive load. Process development trials on production equipment were run to verify readiness to begin short stack electrode fabrication.

(3) Matrices Development

A curtain coater trial was run to establish the feasibility of coating a thin one (1) mil matrix on electrodes. The existing IFC production coater was used. Coating thicknesses of 1.2 and 1.3 mils were obtained by increasing belt speed to the maximum and reducing curtain thickness to a minimum possible with this piece of equipment. The thin electrodes required a carrier to eliminate slipping on the acceleration table belt. Electrodes were taped to the carrier with two sided tape on the leading edge to keep them from moving under the curtain or during deceleration. The bubble pressure of a sample cut from the 4- $\mathrm{ft}^{2}$ electrode curtain coated with 1.2 mil matrix is shown in the following Table 3.3-2.

\section{Table 3.3-2. Curtain Coated Thin Matrix Bubble Pressure}

Bubble Pressure

22 psid

18 psid

16 psid

10 psid

6 psid

5 psid
Compressive Load

$50 \mathrm{psi}$

$40 \mathrm{psi}$

$30 \mathrm{psi}$

$20 \mathrm{psi}$

$10 \mathrm{psi}$

The importance of matrix thickness on bubble pressure was established. Samples were prepared by the wire wound rod coating process. Figure 3.3-1 shows how the bubble pressure oi submicron SiC matrix varies with thickness.

It has been standard practice to use a small amount of Teflon as a binder in the SiC matrix to provide physical integrity. This results in a matrix with marginal wettability due to the hydrophobicity introduced by the Teflon. It was found that the Teflon could be eliminated by using a proprietary dispersant. This resulted in improved matrix wettability. This process was used to make the matrices for the short area stack. 


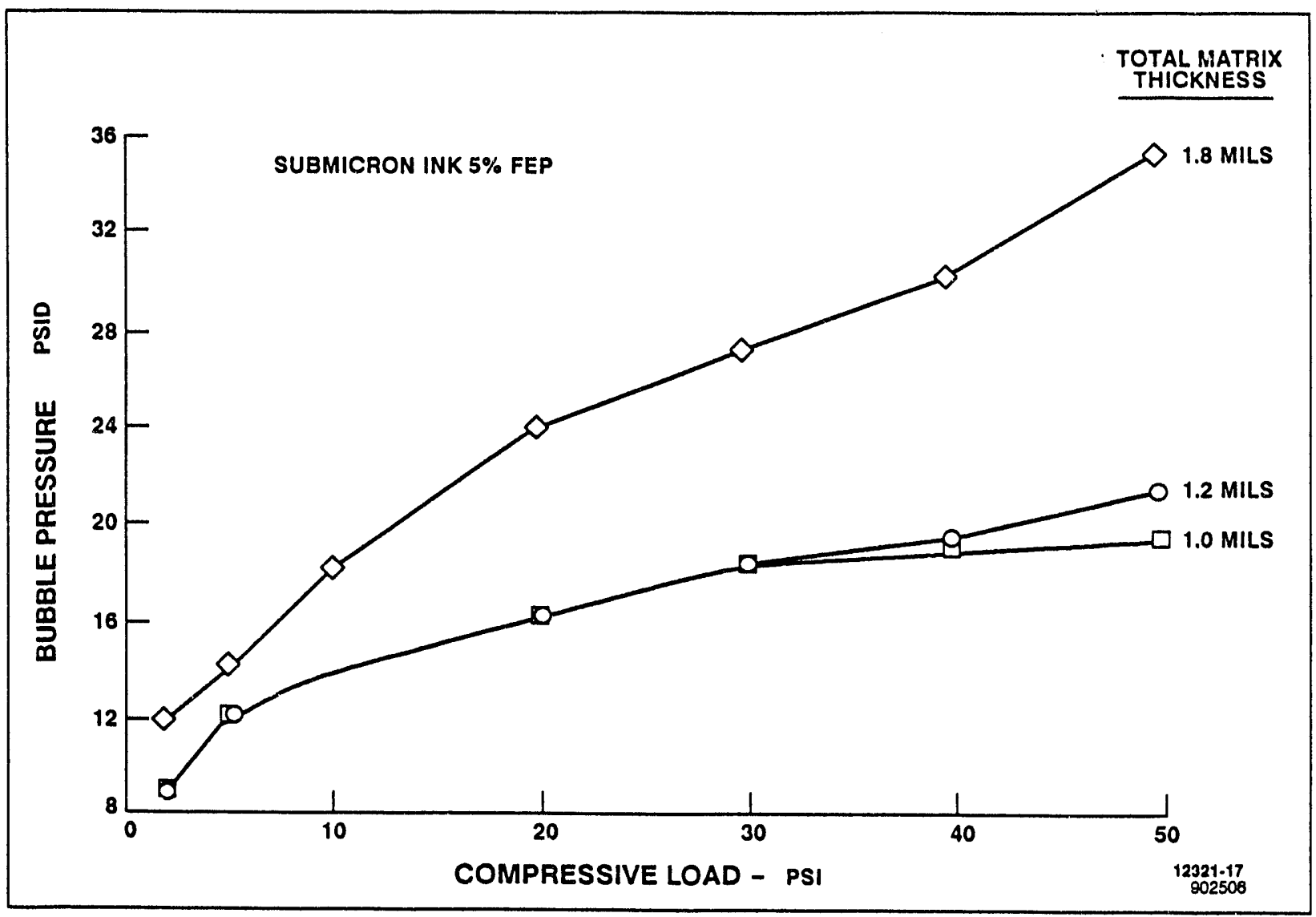

Figure 3.3-1. Thin Matrix Bubble Pressures

(4) Electrode/ERP Edge Seal Development

Subscale work on an alternate polymeric seal concept was pursued. Polymer seals differ from impregnated seals in three ways as shown in Table 3.3-3.

Table 3.3-3. Seal Concepts

Impregnated

Material

Processing

Functional
Submicron Carbon/Graphite

Hydraulic Intrusion of Aqueous Ink

Wet Seal

\section{Polymer}

Fluorcarbon Polymer

Coating or Seals Impervious Coating 
Photomicrographs of edge seal coatings showed the polymer to be only partially filling the ERP's and the surface build up of polymer appeared to provide the seal. One group of samples was made with a single coat of polymeric solution applied with a brush, the second set had two coats. The bubble pressure of the edge seals was over 30 psid. Bubble pressures remained over 30 psid through five thermal cycles from room temperature to $400^{\circ} \mathrm{F}$. The samples were thermal cycled at least 10 times to see if the bubble pressure degrades. Unfortunately, abrasion tests showed a significant loss of sealing, and the coating approach was abandoned.

Fluorocarbon polymer seals were next pursued. While initial testing appeared encouraging, subscale work indicated that dimensional control of channels (to hold seals) was not practical and the effort was discontinued. 


\section{Subtask 3.4 - Cooler}

\section{Objectives}

The objective of this subtask is to develop material and process technology to fabricate coolers $10-\mathrm{ft}^{2}$ in size that meet the technical requirements and cost objectives established in the conceptual design.

\section{Summary}

This subtask included development of two types of advanced cooler holders (molded and commercial graphite) and appropriate encapsulation to protect this cooler from acid attack and corrosion.

\section{Discussion of Activities}

\section{(1) Molded Coolers}

Resins, graphites, and subscale cooler arrays were procured, and subscale 6-inch by 6-inch composites were molded to evaluate four (4) high conductivity graphites. Physical property measurements are shown in Table 3.4-1.

Table 3.4-1. Thermal Conductivity of Molded Cooler Composites 6-Inch by 6-inch Composites Without Arrays

\begin{tabular}{|c|c|c|}
\hline & $\begin{array}{c}\text { Thermal Conductivity } \\
{[\mathrm{Btu} / \mathrm{Hr}-\mathrm{Ft}} \\
\left.{ }^{\circ} \mathrm{F}\right]\end{array}$ & $\begin{array}{c}\text { Thermal Conductivity } \\
\text { as a Fraction of } \\
\text { Baseline }\end{array}$ \\
\hline Baseline & $i 2.8$ & 1.00 \\
\hline Graphite A & 5.0 & 0.39 \\
\hline Graphite B & 11.9 & 0.93 \\
\hline Graphite C & 4.2 & 0.33 \\
\hline Graphite D & 2.6 & 0.20 \\
\hline
\end{tabular}

Full-scale molded cooler assemblies were thermal cycled to measure structural integrity. Blisters and cracks developed in cooler assemblies after only a few thermal cycles. The defects appeared randomly and did not appear to be associated with array location. Post-cure cycles to stabilize the composite were provided by the resin supplier and molder. Two cooler assemblies from the initial full-scale mold trial were post-cured to the recommended cycles in separate runs. Blisters and cracks also developed in both cooler assemblies. A third cooler assembly was post-cured at an even slower ramp rate. The post-cure cycle was completed as planned and resulted in a composite free of cracks and blisters.

Subscale graphite and resin composites were molded by an alternative one-step process to avoid problems cited above. The composites were molded using two types of high conductivity graphites and a range of resin contents. Two samples of each composition were post-baked in separate but identical cycles. Following post-bake, the samples were visually examined for cracks and blisters. The thermal conductivity of all samples surviving post-bake without cracks and blisters were measured. The results of these tests are shown in Table 3.4-2. The composition of sample AE1 was selected for additional development. 


\begin{tabular}{|c|c|c|c|c|c|}
\hline \multicolumn{6}{|c|}{$\begin{array}{l}\text { Table 3.4-2. Post Bake Results for Subscale } \\
\text { Graphite-Resin Composites }\end{array}$} \\
\hline$\underset{\text { Type }}{\text { Graphite }}$ & & $\begin{array}{c}\text { Nominalized } \\
\text { Resin } \\
\text { Content }\end{array}$ & $\begin{array}{l}\text { Post } \\
\text { Baked } \\
\text { Cycle I }\end{array}$ & $\begin{array}{c}\text { Post } \\
\text { Baked } \\
\text { Cycle II }\end{array}$ & $\begin{array}{l}\text { Thermal } \\
\text { Conductivity } \\
\text { Btu/Hr- }{ }^{\circ} \mathrm{F}-\mathrm{Ft}\end{array}$ \\
\hline Graphite A & $\mathrm{AE} 1$ & 1.00 & $\mathbf{Y}$ & $\mathbf{Y}$ & 8.6 \\
\hline Graphite A & $\mathrm{AE} 2$ & 1.12 & $\mathrm{Y}$ & $\mathbf{Y}$ & 8.1 \\
\hline Graphite A & AE3 & 1.27 & $\mathbf{N}$ & $Y$ & \\
\hline Graphite A & $\mathrm{AE} 4$ & 1.38 & $\mathbf{N}$ & $Y$ & \\
\hline Graphite A & AE5 & 1.38 & $\mathbf{N}$ & $\mathbf{N}$ & \\
\hline Graphite A & AE6 & 1.54 & $\mathbf{N}$ & $\mathbf{N}$ & \\
\hline Graphite B & $\mathrm{BE} 4$ & 0.85 & $Y$ & $\mathrm{Y}$ & 8.9 \\
\hline Graphite B & BE3 & 1.00 & $\mathbf{N}$ & $\mathrm{Y}$ & \\
\hline Graphite B & $\mathrm{BE} 2$ & 1.15 & $\mathrm{Y}$ & $Y$ & 6.0 \\
\hline Graphite B & $\mathrm{BE} 1$ & 1.38 & $\mathbf{N}$ & $\mathbf{N}$ & \\
\hline \multicolumn{6}{|c|}{$\begin{array}{l}\text { Legend: } \\
\qquad \text { Y - Survived Post Baking } \\
\text { N - Cracked During Post Baking }\end{array}$} \\
\hline
\end{tabular}

Subscale shimming trials were performed to evaluate methods for centering the cooler tube array in the cooler composite. The shimming trials tested and evaluated several shimming techniques: straight shims of metal wire, Teflon, solid graphite, phenolic-graphite and weaving metal wire between the tubes. The woven metal wire technique worked best.

Several subscale 6 -inch by 6 -inch coolers, molded with tube arrays, were post-baked at $630^{\circ} \mathrm{F}$ in a nitrogen environment for two days. No cracking or blistering of the coolers was introduced by the post-baking. The thermal stability of the post-baked parts was verified by thermal cycling a post baked cooler ten times at $400^{\circ} \mathrm{F}$.

Thermal resistance measurements of subscale coolers indicated a value 2.3 times the baseline cooler. Photomicrographic examination revealed density vari. tions throughout the thickness of the sample and a poor tube to composite bond. A subscale cooler was next molded with a tube array treated to enhance the bonding between the tube and composite. This treatment was conceived to eliminate the gap at the tube and composite interface to improve thermal performance. The treatment was evaluated in subscale 6-inch by 6-inch coolers. Results are shown in Table 3.4-3. 


\begin{tabular}{|l|c|}
\hline \multicolumn{2}{c|}{ Table 3.4-3. Thermal Performance Comparison } \\
Subscale 6 inch $\times 6$ inch Coolers \\
Description & $\begin{array}{c}\text { Thermal Resistance } \\
\mathrm{Hr} \mathrm{Ft}^{2}{ }^{\circ} \mathrm{F} / \mathrm{Btu}\end{array}$ \\
\hline Goal & $8.00 \times 10^{-3}$ \\
Array Without Treatment & $12.30 \times 10^{-3}$ \\
Array With Treatment & $8.05 \times 10^{-3}$ \\
\hline
\end{tabular}

Photomicrographs of the treated tube array in subscale composites showed no gap at the tube and composite interface. A subscale 6-inch by 6-inch cooler with a treated tube array was thermal cycled 33 times to $400^{\circ} \mathrm{F}$. As shown in Figure 3.4-1, thermal resistance increased by only 10 percent.

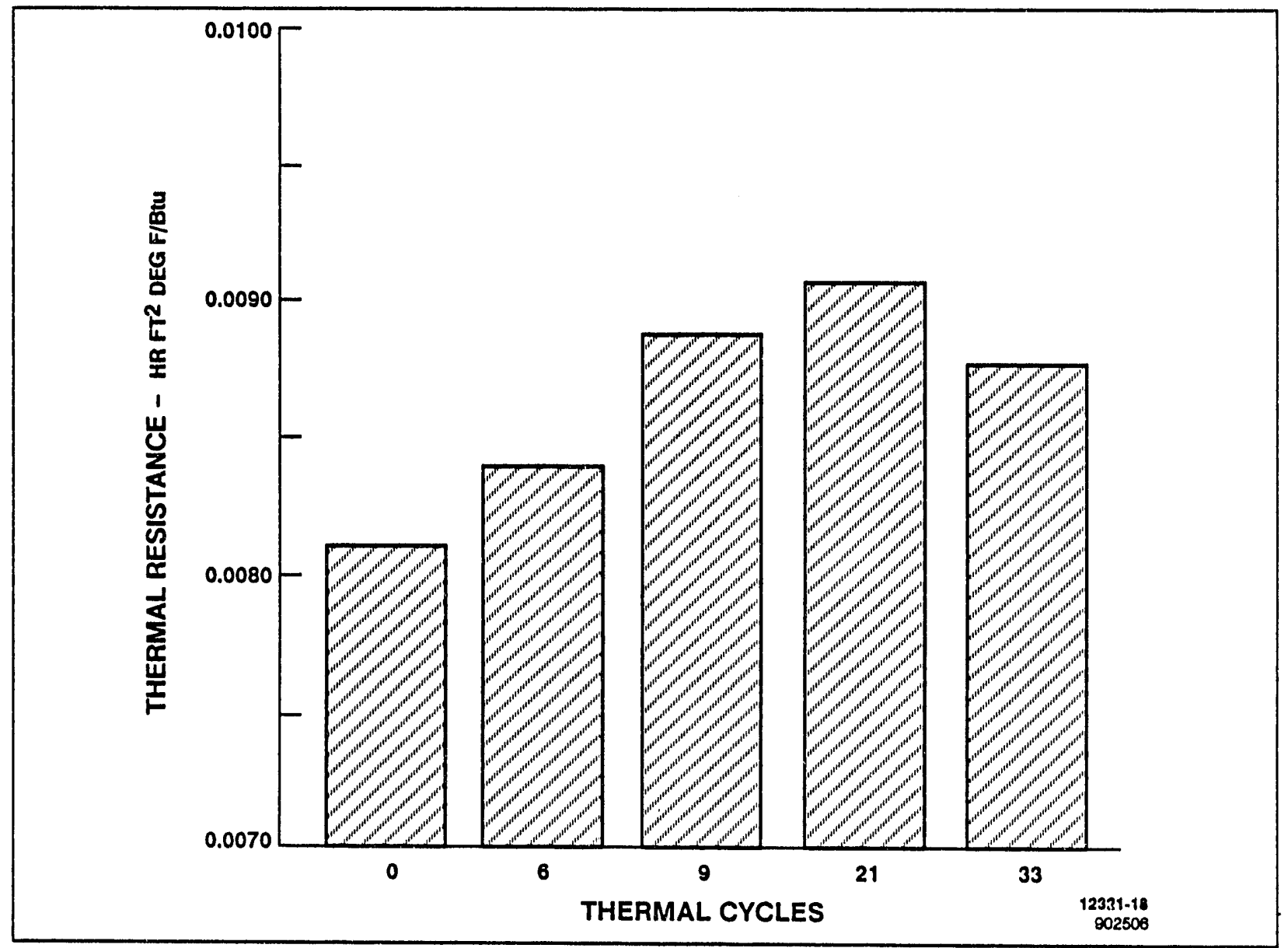

Figure 3.4-1. Thermal Resistance as Function of Thermal Cycling for Subscale Molded Cooler

Molding trials of full-size coolers were then conducted to improve the mold compound deposition, to reduce or eliminate bowing of the finished composite, and to further evaluate molding with arrays treated to eliminate gaps between the tube and resin/graphite matrix. 
A mold compound feeder was fabricated to shorten the mold cycle while providing a more uniform thickness of mold material across the mold. The feeder functioned satisfactorily, although modifications will be required to completely eliminate manual material leveling and to shorten the processing time.

Five full-size coolers were molded after completing the feeder capability trials. The first three (3) coolers were molded with process parameters varied to optimize array centering. The last two (2) coolers contained treated arrays and were successfully molded with the selected parameters and were flat and free of cracks after post-bake.

A flattening cycle was developed concurrently during the molded trials to eliminate a bow in the assembly that developed after removal from the mold. The bowing condition was observed in the earlier full-size molding trials, and is attributable in large part to the current method used to extract the cooler from the mold. Flattening was achieved in a cold press under load.

(2) Commercial Graphite Cooler Holders

Commercial graphite was also evaluated as an alternative to the molded cooler holder. Three different graphite grades were evaluated in subscale 6-inch by 6-inch laminating trials to evaluate handleability, $\mathrm{iR}$, and acid protection. The results are shown in Table 3.4-4. Graphite $\mathrm{Y}$ was selected for additional evaluation.

\begin{tabular}{|c|c|c|c|}
\hline \multicolumn{4}{|c|}{ Graphite Material Grades } \\
\hline Parameter & Type X & Type Y & Type Z \\
\hline $\mathrm{iR}$ & $1 \mathrm{mV} / 100 \mathrm{ASF}$ & $1 \mathrm{mV} / 100 \mathrm{ASF}$ & $5-10 \mathrm{mV} / 100 \mathrm{ASF}$ \\
\hline $\begin{array}{l}\text { Electrolyte } \\
\text { Barrier }\end{array}$ & $\begin{array}{l}\text { Baseline } \\
\text { Barrier }\end{array}$ & $\begin{array}{l}\text { Baseline } \\
\text { Barrier }\end{array}$ & $\begin{array}{l}\text { Too dense to employ } \\
\text { Baseline Barrier }\end{array}$ \\
\hline Handleability & $\begin{array}{l}\text { To weak to be } \\
\text { machined at full } \\
\text { size }\end{array}$ & Acceptable & Acceptable \\
\hline
\end{tabular}

Subscale 6-inch by 6-inch cooler assemblies were fabricated with the commercial graphite plate and a baseline holder. Grooves were machined to specification and inspected for compliance. Subassemblies and the final assemblies were $\mathrm{iR}$ tested to requirements and passed.

Testing was conducted in the 6-inch by 6 -inch thermal resistance rig at identical conditions. Both test pieces had acceptable and essentially identical thermal resistance (Table 3.4-5).

Table 3.4-5. Subscale Cooler Thermal Performance

$\begin{array}{cc}\begin{array}{c}\text { Control Holder } \\ \text { Material }\end{array} & \text { Thermal Resistance } \\ \mathbf{H r} \mathbf{F t}^{2}{ }^{\circ} \mathbf{F} / \text { Btu }\end{array}$

Baseline

0.0074

Commercial Graphite

0.0072 
A small area (4-ft²) cooler assembly was fabricated using commercial graphite plates for the holders. This cooler was evaluated in a full-scale heat transfer rig. The rig accumulated 18 thermal cycles and was loaded from 10 to $50 \mathrm{psi}$ axial loads, which covers the axial load range from the beginning to end of life. The test results as summarized in Table 3.4-6 are consistent with values measured in full-size stacks and indicate adequate tolerance to axial load variations.

A small area cooler incorporating a commercial graphite cooler holder was inspected after heat transfer tests. The test which consisted of eighteen thermal cycles at $350^{\circ} \mathrm{F}$ did not result in any cracks or degradation to the cooler.

\begin{tabular}{|cc|}
\hline Table 3.4-6. & Small Area Cooler Performance \\
\hline $\begin{array}{c}\text { Axial Load } \\
\text { PSI }\end{array}$ & $\begin{array}{c}\text { Thermal Resistance } \\
\mathbf{H r ~ F t}^{2}{ }^{\circ} \mathbf{F} / \text { Btu }\end{array}$ \\
\hline 50 & .0124 \\
20 & .0130 \\
10 & .0142 \\
\hline
\end{tabular}

\section{(3) Cooler Encapsulation}

The series of component tests aimed at evaluating edge seal and cover plate approaches to encapsulate advanced coolers were conducted to prevent electrolyte penetration. Test conditions were selected to be severe in an attempt to accelerate the findings.

The following candidate edge seal materials and configurations were considered:

- Acid barrier materials included fluoroelastomer, fluoropolymer, and composite coatings, films and sheets.

- Edge configurations consisted of graphite "picture frames" and frameless designs formed by extending the cooler holders to the finished planform dimension.

Results of first round coating evaluations indicated additional in-cell testing would be required to substantiate the use of coatings as a primary acid barrier. Coating imperfections were quickly penetrated by dye and eventually by acid. Because of this result, coatings were used only as secondary barriers and eliminated from consideration as primary barriers.

The first round of subscale testing also deferred development of frameless coolers. Breaches were detected at the uncoated seam between coated holder edges and viable manufacturing approaches to bridge the two holder edges with film or tape required significant additional development.

The balance of the cooler edge seal evaluation was directed toward acid barrier integrity improvement and simplification of the picture frame edge seal approach. The primary acid barriers were limited to fluoropolymer and fluoropolymer composite films that were shown to resist dye penetration in the first round of subscale testing.

Four edge seal approaches were selected for additional testing. The approaches are described in Table 3.4-7 and the results are shown in Table 3.4-8. 


\begin{tabular}{|c|c|c|c|}
\hline \multicolumn{4}{|c|}{$\begin{array}{l}\text { Table 3.4-7. Cooler Edge Seal Encapsulation Approaches } \\
\text { Picture Frame Edge Seal } \\
\text { Commercial Graphite Cooler Holders } \\
\text { Fluoropolymer/Graphite Cover Plates }\end{array}$} \\
\hline $\begin{array}{c}\text { Seal } \\
\text { Approach }\end{array}$ & External Seal & Internal Seal & $\begin{array}{l}\text { Picture Frame } \\
\text { Shape }\end{array}$ \\
\hline 1 & $\begin{array}{l}\text { Fluoropolymer } \\
\text { Coating }\end{array}$ & $\begin{array}{l}\text { Fluoropolymer } \\
\text { Composite }\end{array}$ & Rectangular \\
\hline 2 & $\begin{array}{l}\text { Fluoropolymer } \\
\text { Coating }\end{array}$ & $\begin{array}{l}\text { Fluoropolymer } \\
\text { Film }\end{array}$ & Rectangular \\
\hline 3 & $\begin{array}{l}\text { Fluoropolymer } \\
\text { Coating }\end{array}$ & $\begin{array}{l}\text { Two Fluoropolymer } \\
\text { Film }\end{array}$ & $\begin{array}{l}\text { Rectangular } \\
\text { and ' } L \text { ' }\end{array}$ \\
\hline 4 & $\begin{array}{l}\text { Fluoropolymer } \\
\text { Coating }\end{array}$ & $\begin{array}{l}\text { Fluoropolymer } \\
\text { Film }\end{array}$ & 'L' \\
\hline
\end{tabular}

\begin{tabular}{|c|c|c|c|c|c|}
\hline \multicolumn{6}{|c|}{$\begin{array}{c}\text { Table 3.4-8. Cooler Edge Seals } \\
\text { Encapsulation Trials }\end{array}$} \\
\hline $\begin{array}{l}\text { Seal } \\
\text { Edge } \\
\text { Approach }\end{array}$ & $\begin{array}{l}\text { Thermal } \\
\text { Cycle } \\
\text { at } 400^{\circ} \mathrm{F} \\
\text { W/Acid }\end{array}$ & $\begin{array}{c}\text { Acid Thru Outer } \\
\text { Edge Barrier } \\
\text { Yes/No }\end{array}$ & $\begin{array}{c}\text { Dye Thru Outer } \\
\text { Edge Barrier } \\
\text { Yes/No }\end{array}$ & $\begin{array}{c}\text { Acid Thru Inner } \\
\text { Edge Barrier } \\
\text { Yes/No }\end{array}$ & $\begin{array}{c}\text { Dye Thru Inner } \\
\text { Edge Barrier } \\
\text { Yes/No }\end{array}$ \\
\hline 1 & $\begin{array}{l}\text { Yes } \\
\text { Yes } \\
\text { Yes } \\
\text { Yes }\end{array}$ & Yes at $94 \mathrm{Hrs}$. & Yes at $168 \mathrm{Hrs}$. & $\begin{array}{l}\text { No at } 94 \mathrm{Hrs} . \\
\text { No at } 408 \mathrm{Hrs} \text {. } \\
\text { No at } 600 \mathrm{Hrs} \text {. } \\
\text { No at } 840 \mathrm{Hrs} .\end{array}$ & No at $168 \mathrm{Hrs}$. \\
\hline 2 & $\begin{array}{l}\text { Yes } \\
\text { Yes } \\
\text { Yes } \\
\text { Yes }\end{array}$ & $\begin{array}{l}\text { No at } 72 \text { Hrs. } \\
\text { Yes at } 384 \text { Hrs. }\end{array}$ & Yes at $72 \mathrm{Hrs}$. & $\begin{array}{l}\text { No at } 72 \mathrm{Hrs} . \\
\text { No at } 384 \mathrm{Hrs} \text {. } \\
\text { No at } 576 \mathrm{Hrs} \text {. } \\
\text { No at } 816 \mathrm{Hrs} \text {. }\end{array}$ & No at $72 \mathrm{Hrs}$. \\
\hline 3 & $\begin{array}{l}\text { Yes } \\
\text { Yes }\end{array}$ & $\begin{array}{l}\text { No at } 48 \mathrm{Hrs} \text {. } \\
\text { Yes at } 312 \mathrm{Hrs} \text {. }\end{array}$ & Yes at $48 \mathrm{Hrs}$. & $\begin{array}{l}\text { No at } 48 \mathrm{Hrs} \text {. } \\
\text { No at } 312 \mathrm{Hrs} \text {. }\end{array}$ & $\begin{array}{l}\text { No at } 48 \mathrm{Hrs} \text {. } \\
\text { No at } 312 \mathrm{Hrs} \text {. } \\
\text { No at } 487 \mathrm{Hrs} \text {. }\end{array}$ \\
\hline 4 & $\begin{array}{l}\text { Yes } \\
\text { Yes } \\
\text { Yes }\end{array}$ & No at $126 \mathrm{Hrs}$. & Yes at $126 \mathrm{Hrs}$. & $\begin{array}{l}\text { No at } 126 \mathrm{Hrs} \text {. } \\
\text { No at } 456 \mathrm{Hrs} \text {. } \\
\text { No at } 624 \mathrm{Hrs} \text {. } \\
\text { No at } 1104 \mathrm{Hrs} \text {. }\end{array}$ & $\begin{array}{l}\text { No at } 126 \mathrm{Hrs} \text {. } \\
\text { No at } 624 \mathrm{Hrs} \text {. } \\
\text { No at } 1104 \mathrm{Hrs} \text {. }\end{array}$ \\
\hline
\end{tabular}


Subscale coolers were also made with fiber-reinforced fluoropolymer composite cover plates. The results from the dye tests for the subscale coolers are summarized in Table 3.4-9. Sample D, made with configuration three (3) edge seals, was tested in dye for 1773 hours. The results indicated the edge seal and cover plate performed as designed and fiber-reinforced covers with this edge configuration were selected for a cooler in the small area development stack.

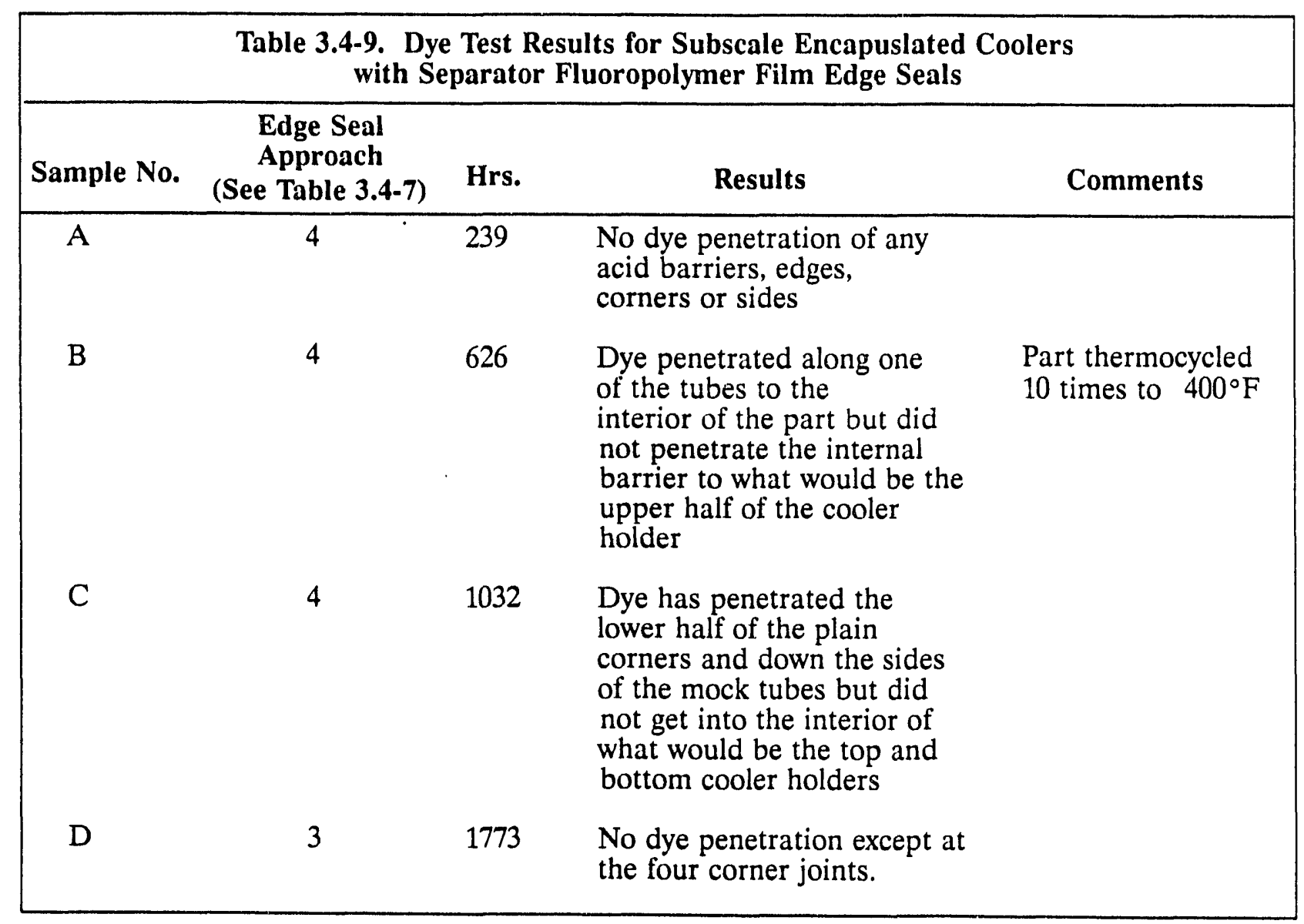




\section{TASK 4 - STACK DESIGN}

\section{Objectives}

The objective of this task is to update the full-scale conceptual design and to define designs for two stacks and one $10-\mathrm{ft}^{2}$ subscale stack.

\section{Summary}

Design drawings and descriptive material were prepared for the fabrication of repeat and non-repeat parts and assembly of the short stacks tested in this program. Drawings were updated to reflect "as built" characteristics after the stacks were built.

Periodically, the conceptual design was also updated to reflect new information learned during the fabrication, assembly, and test of the short stacks. These updates have been incorporated into the conceptual design description in Task 1 of this report.

\section{Discussion of Activities}

(1) Small Area Development Stack

Small area development stack was designed for operation at either ambient or pressurized operation. Key features are listed in Table 4.1-1.

\section{Table 4.1-1. Small Area Development Stack Description}

- 4.8- $\mathrm{ft}^{2}$ active area Configuration "B" cells with GSB-18 catalyst

- 28 cells

- 7 cells per cooler, 4 substacks

- Commercial graphite coolers

- Integral end-plates for axial load compression, power take-off and manifold sealing

- Coated carbon steel manifolds

- 160 psig MAWP vessel (for pressurized test only)

The layout drawing for pressurized operation located the small area stack in the rig pressure vessel to establish fluid, electrical and instrumentation interfaces and clearances. A reactant manifold shell assembly was designed incorporating those features common to both fuel and air manifolds. Common features included manifold size, retention brackets to provide loading for manifold seals, drain bosses, and instrumentation bosses. The stack pressure plate and the adapter support plate to mount the 28-cell small area stack in the rig pressure vessel were completed. The fluid, electrical, and instrumentation routing between the stack assembly and vessel were also defined.

Drawings of repeat parts were prepared and updated in coordination with development activities in Task 3. Drawings for electrodes, integral separators, molded coolers, and commercial graphite coolers were included in the design package. These drawings were used to build the short stack. After fabrication and assembly of the small area development stack, the drawings were updated to reflect "as-built" characteristics. 
(2) First $10-\mathrm{Ft}^{2}$ Subscale Stack

Repeat part, non-repeat, and assembly drawings for the first $10-\mathrm{ft}^{2}$ subscale stack were prepared. Repeat part drawings included anodes, cathodes, integral separators, and coolers. Non-repeat drawings described manifolds and end-plates. Stack assembly drawings showed the stacking of repeat parts, the addition of non-repeats, and details for mounting into the containment vessel. A general description of the stack is provided in Table 4.1-2.

Following review and approval of the designs, these drawings were used to fabricate the stack. After completing stack assembly, the drawings were updated to match "as-built" characteristics.

\section{Table 4.1-2. First $10-\mathrm{Ft}^{2}$ Subscale Stack Description}

- $10-\mathrm{ft}^{2}$ active area Configuration " $\mathrm{B}$ " cells with GSB-18P catalyst

- 25 cells

- 5 cells per cooler, 5 substacks

- Commercial graphite coolers

- Partially-integrated end-plates for axial load compression and power take-off

- Coated carbon steel manifolds

- 160 psig MAWP vessel

(3) Small Area On-Site Stack

Existing drawings from complementary programs were utilized for cell stack fabrication and assembly. Material describing design features of this stack was reviewed and approved before delivery of the stack assembly to the test facility.

The stack contains 32 cells with coolers sfaced between every eight cells. The stack includes processing changes intended to improve seal integrity and performance stability at increased production rates when compared to earlier stacks testeci on this program. 


\section{TASK 5 - FABRICATION}

\section{Subtask 5.1 - Repeat Components \\ Objective}

The objective of this effort was to fabricate the repeat components for two small area stacks and one 10 -ft² subscale stack each consisting of approximately 30 cells. These stacks will be of the Configuration B cell design. The repeat components consist of the substrates, electrodes, electrolyte reservoir plates, and cooler assemblies.

\section{Summary}

Repeat parts for the small area development stack and the first $10-\mathrm{ft}^{2}$ subscale stack were successfully fabricated utilizing processing information developed in Task 3.

Repeat parts for the small area on-site stack were furnished by a complementary program at no cost to this program.

\section{Discussion of Activities}

\section{(1) Fabrication of Parts for the Small Area Development Stack}

Inspection of a batch of 100 full-size thin substrates graphitized in an experimental one-step heat treat process indicated the substrates were too wavy to process without breakage, and a second batch of full-size thin substrates were graphitized by the one-step heat treat process and found to be usable. In addition, substrates from Vendor $\mathrm{A}$ were purchased and used for a portion of the parts.

The thin substrates were trimmed to rough planform, density checked and treated to improve wettability. The holdout coat was screen printed and the electrodes were catalyzed and imnrerm seals. Next, the fillerband was applied by the curtain coating process and th , la a $_{\mathrm{x}} \mathrm{x}$ applied by a Gravure coater before finished electrodes were delivered for stack assembly.

One hundred and fifty (150) electrolyte reservoir plates (ERP's) were formed, heat treated, microground, and then impregnated with a small particle size graphite to create an edge seal. These ERP's were processed into integral separator plates (ISP's).

Fabrication of ISP's for the small area test stack was also completed. Three (3) types of ISP's (see Subtask 3.2) were fabricated and installed in the stack for a "side-by-side" evaluation.

The 3/8 inch diameter cooler array was selected for the short stack and arrays were obtained. Five (5) cooler assemblies with two types of encapsulation methods were fabricated for the short stack. One cooler features an ISP cover with a Configuration 5 (see Task 3.4) edge seal barrier. The second cooler type fabricated features a conventional on-site cover plate with an internal fluoropolymer acid barrier formed at final assembly. All coolers employed commercial graphite cooler holders.

(2) Fabrication of Parts for the First 10- $\mathrm{Ft}^{2}$ Subscale Stack

Having completed repeat parts for the small area development stack last year, attention was focused on fabricating repeat parts for the $10-\mathrm{ft}^{2}$ stack.

Approximately 400 particulate electrolyte reservoir plates, of the $10-\mathrm{ft}^{2}$ planform, were formed on the double belt process. Parts were then microground, carbonized, impregnated, graphitized, and readied for the next assembly step. Laminated parts from a complimentary program (DE-AC21-83FE60338) were also processed and made available for assembly. 
Anode catalyst was procured, qualified, and prepared for deposition on substrates. Electrodes were processed using approximately 130 substrates formed for IFC and 150 substrates purchased from a supplier (termed Vendor A). Cathodes utilized GSB-18P catalyst developed by a complimentary program (DE-AC21-83FE60338). As with the anodes, both IFC and Vendor A substrates were used to make cathodes. Fillerbands were printed on electrodes after catalyzation. Edge seal impregnation followed fillerband application. Electrodes were final trimmed using production equipment with only minor scrap. Matrix coating, also done on conventional $10-\mathrm{ft}^{2}$ production equipment, produced a thin matrix. Electrodes were inspected, minor matrix defects repaired, and the finished electrodes were delivered to assembly.

Preparation for laminating integral separator plates required development of special tooling to align detailed parts. Parts for each substack, plus spares, were laminated after trials defined the proper lamination conditions. Following lamination, the ISP's were trimmed and machined.

Details for cooler manufacture were procured, and subassembly lamination, machining, and array assembly were completed. Final cooler assembly by a lamination process was also completed. 


\section{Subtask 5.2 - Non-Repeat Components}

\section{Objective}

The objective of this effort was to fabricate the non-repeat components for two small area stacks and one 10 - $\mathrm{ft}^{2}$ subscale stack each of approximately 30 cells each. These stacks will be of the Configuration-B cell design. The non-repeat components consist of the reactant manifolds, coolant manifolds, axial load system, power take-off hardware, and the pressure containment vessel.

\section{Summary}

Non-repeat parts required to complete the assembly of the small area development stack and the $10-\mathrm{ft}^{2}$ subscale stack and mount the two stacks into the pressure vessel were fabricated.

New non-repeat parts for the small area on-site stack were provided by a complementary program at no cost to this program. 


\section{Subtask 5.3 - Stack Assembly \\ Objective}

The objective of this effort is to assemble two small area stacks and one $10-\mathrm{ft}^{2}$ subscale stack of Configuration-B cells.

\section{Summary}

Assembly of the small area development stack and the $10-\mathrm{ft}^{2}$ subscale stack were completed in April 1990 and February 1991, respectively. Work entailed filling of repeat cell parts from Subtask 5.1 with acid electrolyte, stacking of the repeat parts, installation of instrumentation and non-repeats from Subtask 5.2, and checkouts to ensure proper assembly and safe operation.

Assembly of the small area on-site stack was conducted in a similar manner under a complementary program at no cost to this program.

\section{Discussion of Activities}

(1) Small Area Development Stack

A mock-up of the stack was fabricated so that the test stand/stack interfaces could be defined prior to delivering the actual stack to test. The non-repeat hardware was assembled on the mock-up to verify hardware fit and to define the piping datums.

The assembly instructions for the small area development stack were completed. Electrode and ISP acid fill were performed.

Assembly of the small area stack was completed in April, 1990. Assembly followed the general guidelines defined in Table 4.1-1 of the Design Task. The stack was assembled with part variations listed below:

- Three types of integral separator plates

- Improved skived film separators

- Fiber reinforced separators

- Enhanced graphite separators

- Two types of electrode substrates

- Substrates formed for IFC

- Vendor A substrates

- Two types of cooler encapsulation

- Fiber reinforced covers

- Graphite covers

(2) First $10-\mathrm{ft}^{2}$ Subscale Stack

Stack assembly procedures were written using the stack assembly drawing as a basis.

Assembly of the first $10-\mathrm{ft}^{2}$ subscale stack was initiated in January, 1991. The electrodes and electrolyte reservoir plates were filled with electrolyte. The parts were stacked and axially loaded to 50 psi. The stack followed the general design description listed in Table 4.1-2 of the Stack Design Task. Cell features included in the 25-cell assembly are listed below:

- All cathodes catalyzed with GSB-18P

- Two types of electrolyte reservoir plates

- Particulate graphite ERP's

- Laminated ERP's formed for IFC 
- Integral separator plates fabricated with enhanced graphite separator plates

- Two types of electrode substrates

- Substrates formed for IFC

- Vendor A substrates

Instrumentation was added to the stack. Voltage leads were installed in all four corners of each cell. Approximately one hundred cell thermocouples were positioned throughout the stack.

Manifolds and other non-repeats were applied and the stack was delivered to test in February after successfully completing leak tests. After mounting the stack on the vessel base, the reactant leak tests were repeated and the coolant system was hydro-tested. After successfully completing electrical checks, the stack was insulated, and the pressure vessel was closed. Figure 5.3-1 shows the dome being installed.

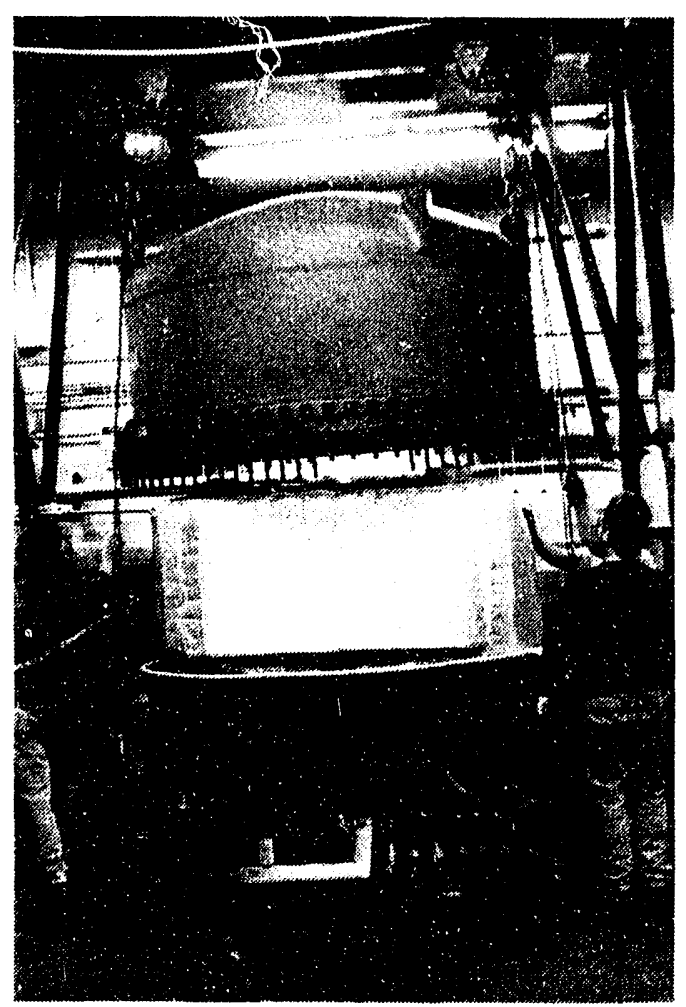

(PUBS 8249)

Figure 5.3-1. Vessel Dome Being Installed on 10- $f^{2}$ Stack 


\section{Subtask 5.4 - Cost Assessment}

\section{Objective}

The objective of this task was to estimate the manufactured cost of the full-height $10-\mathrm{ft}^{2}$ ConfigurationB cell stack assembly defined in the conceptual design activities in Task 1.

\section{Summary}

Manufacturing logs, vendor quotes and estimates were used to calculate a manufactured stack cost for a full-height stack and pressure vessel. The basis for cost estimates and the resultant cost estimates were reviewed with an independent contractor. The independent contractor completed the audit, prepared a report, and reviewed the audit results in a meeting held at METC. 


\section{TASK 6 - STACK TESTING}

\section{Subtask 6.1 - Small Area Development Stack Test}

\section{Objective}

The objective of this task is to obtain early feedback on improved Configuration-B cell packages at atmospheric and pressurized operating conditions.

\section{Summary}

The small area development short stack was successfully tested for 2377 hours at atmospheric conditions and 677 hours at 120 psia.

\section{Discussion of Activities}

(1) Ambient Pressure Testing

Following a test stand checkout and safety review, the small area short stack was mounted in the test stand.

Ambient pressure testing of the 28-cell stack was conducted in the Spring and Summer of 1990. Total test time was 2377 hours with ten thermal cycles and thirteen load cycles. Stack testing was conducted in a manner which represented the expected operation of future power plants. After completing simulated stack and power plant acceptance tests, stack operation was alternated between two power profiles:

1. Constant 200 ASF load to simulate grid-connect applications or constant load settings.

2. Variable load between 50 and 220 ASF to simulate grid-connect on grid-independent applications with load-following requirements.

Nominal test conditions were $14.7 \mathrm{psia}, 80 \%$ fuel utilization and $60 \%$ air utilization. The cell stack temperature was varied as a function of current density (ASF) to simulate power plant operating conditions, which reach approximately $400^{\circ} \mathrm{F}$ at $200 \mathrm{ASF}$.

A summary of test activities is shown in Table 6.1-1. A non-destructive inspection of the cell stack was conducted at 2206 test hours. It consisted of the standard axial load measurement, standard reactant gas cross-leakage measurement, and removal of the air exit manifold to permit a visual inspection of the air exit stack face. Visually, the air exit stack face was in excellent condition. The stack edges were dry, with no indications of corrosion. The stack was reassembled and a brief test at 200 ASF conducted to confirm operational integrity.

Figure 6.1-1 shows the average cell performance history at 200 ASF for substacks No. 2 and No. 3. (These two substacks were the most representative of full-size stack thermal profiles and nearly identical to the temperature-corrected average of the stack). The change in performance at 2207 hours of test time was primarily a result of the interim stack inspection. The performance of all four substacks was stable. 


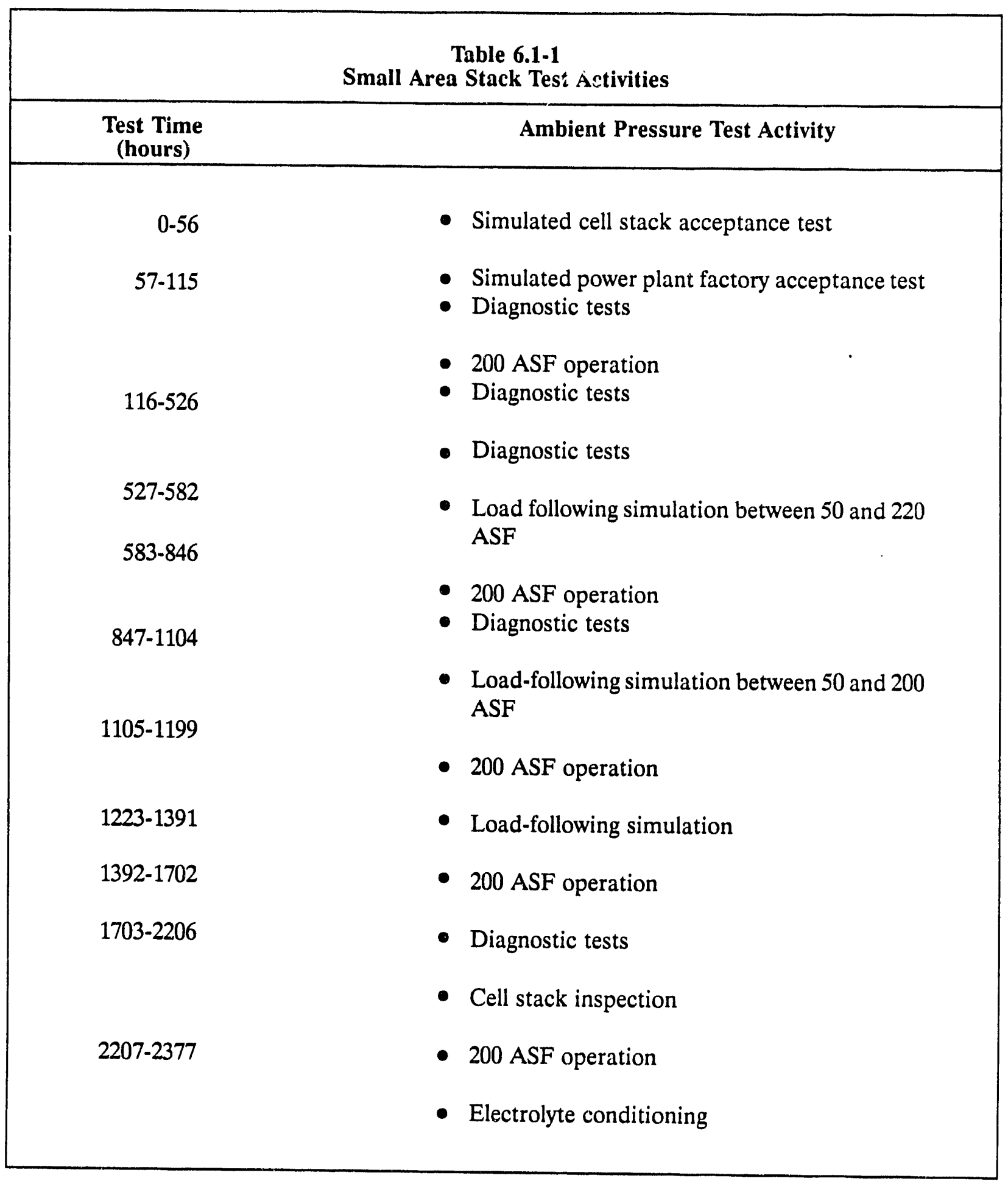




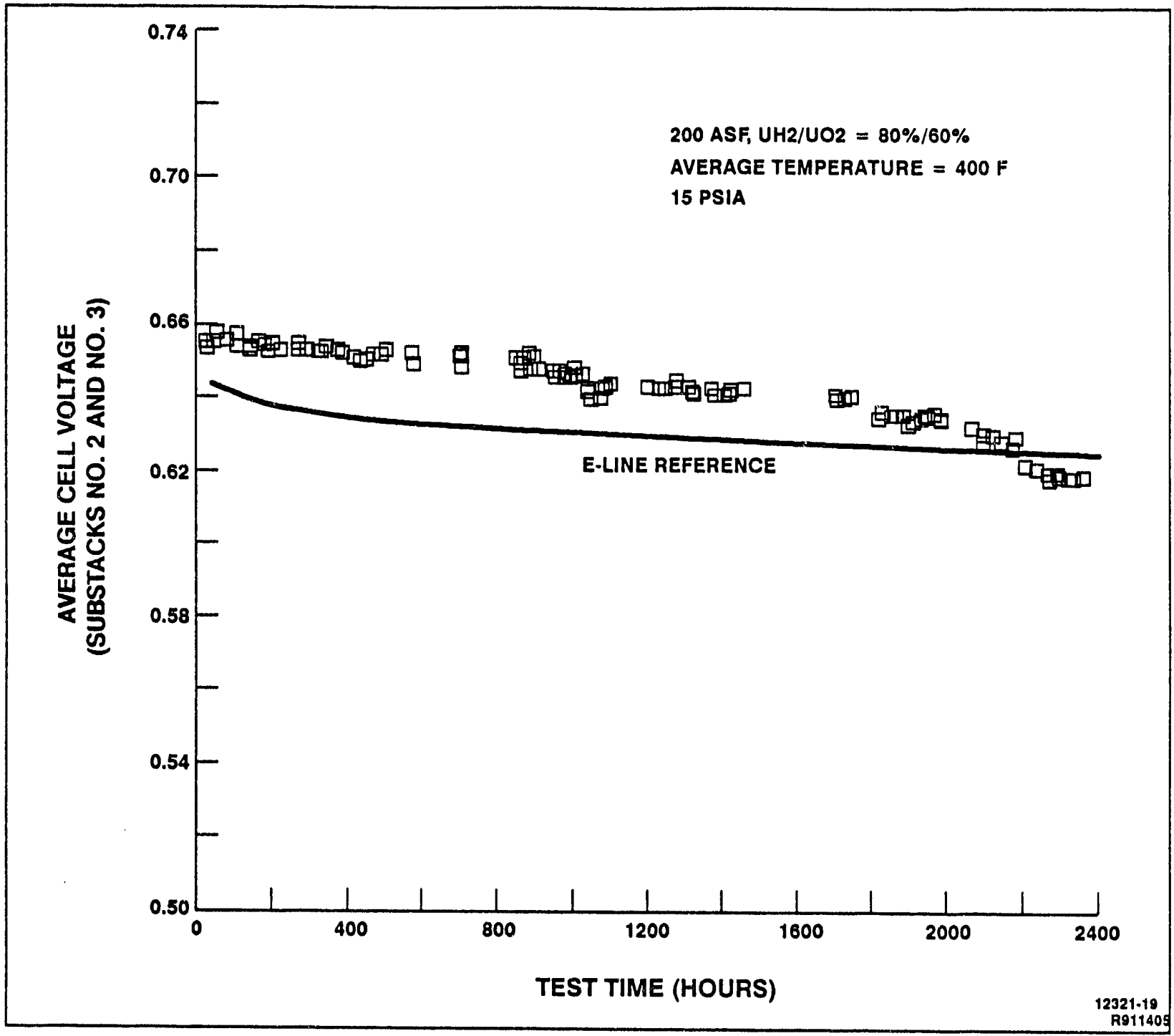

Figure 6.1-1. Ambient Pressure Performance History of the Small Area Development Stack

The four performance calibrations conducted are shown in Figure 6.1-2. Grid independent performance data was used for the 1150 test hour calibration points.

Average cell performance sensitivity to changes in fuel utilization were evaluated at 85 test hours, 900 test hours and 2195 test hours. This data is presented in Figure 6.1-3. Similarly, average cell performance sensitivity to changes in air utilization were measured at 87 test hours, and 2105 test hours. This data is shown in Figure 6.1-4. 


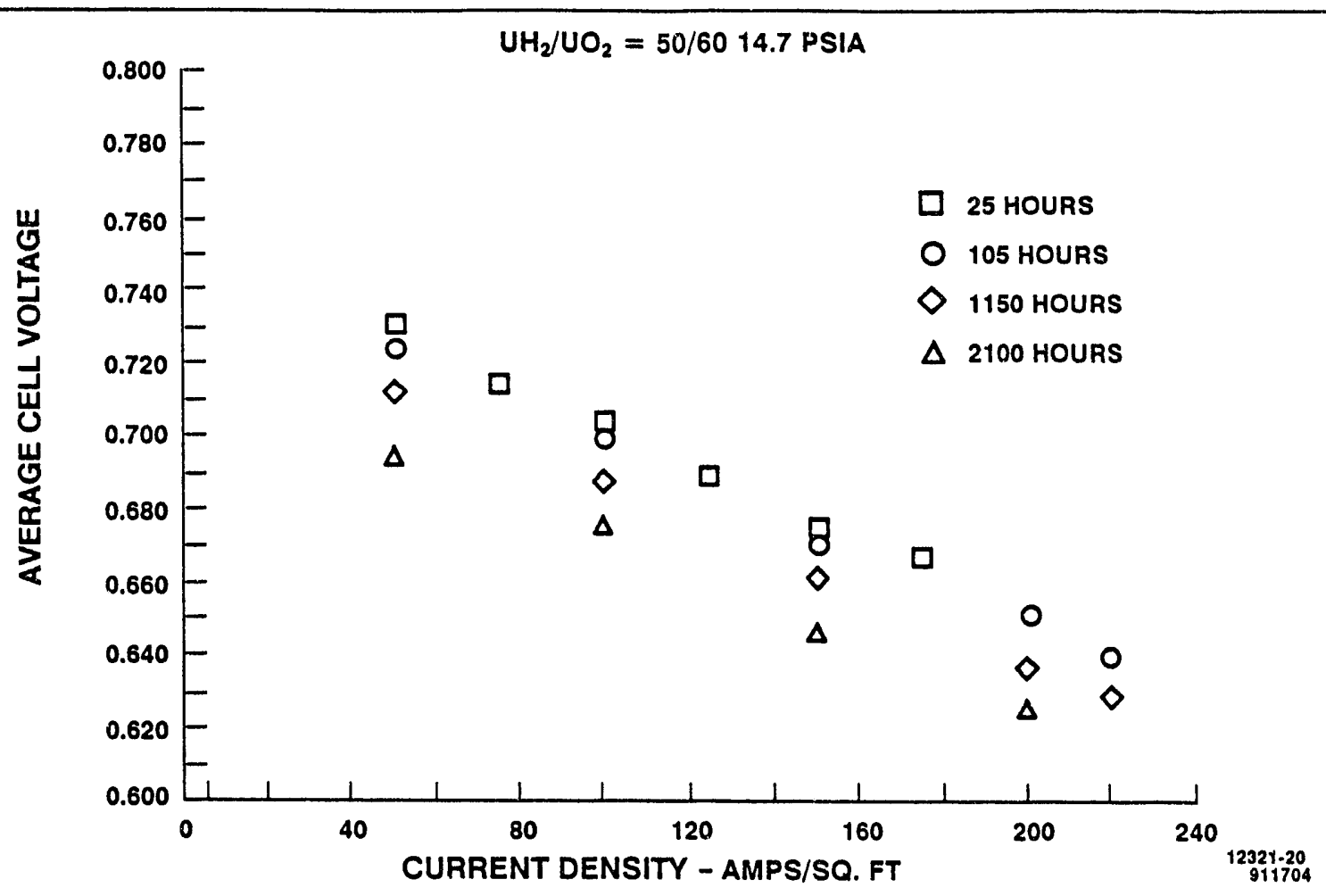

Figure 6.1-2. Performance Calibration of the Small Area Development Stack

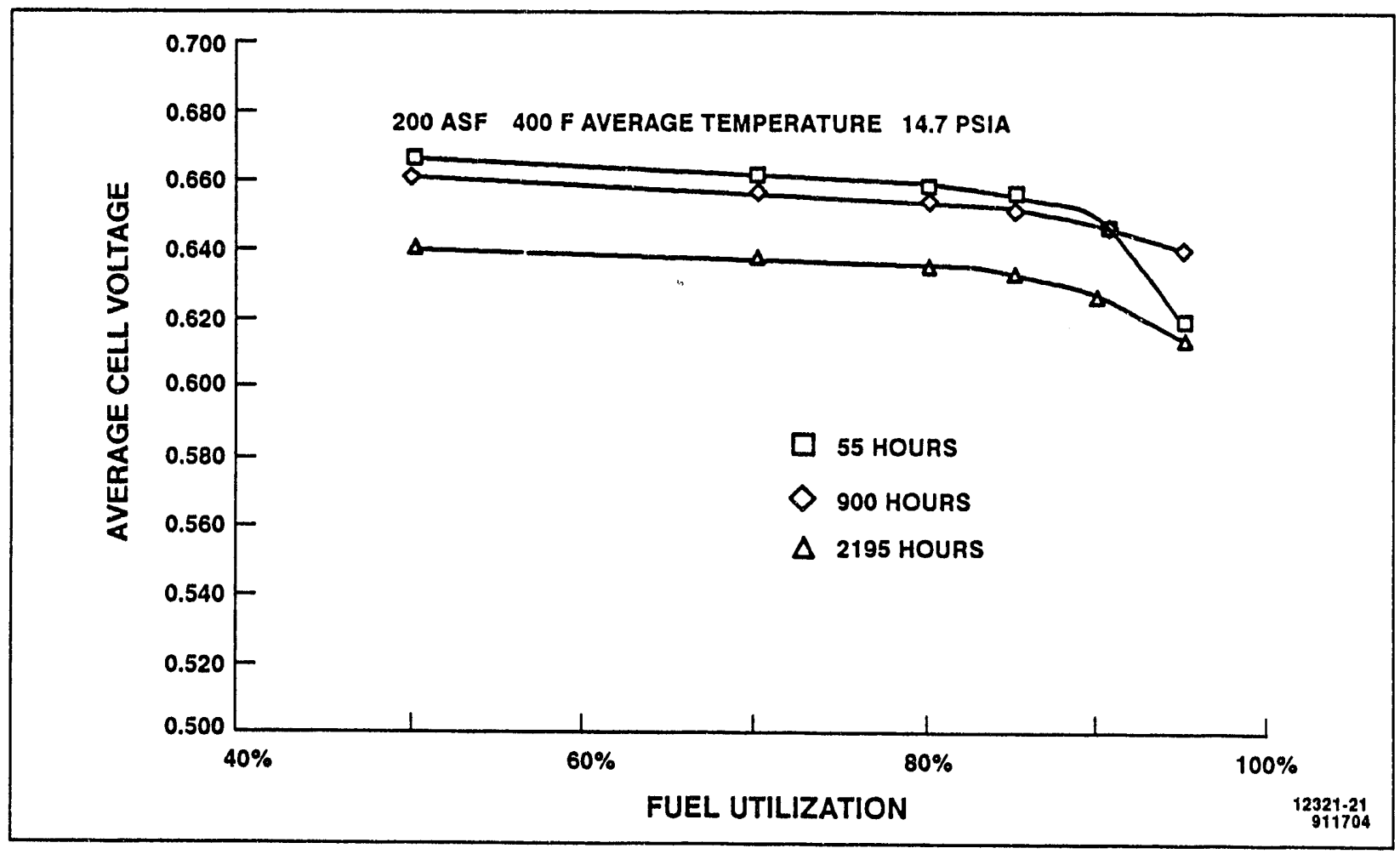

Figure 6.1-3. Fuel Utilization Sensitivity of the Small Area Development Stack 


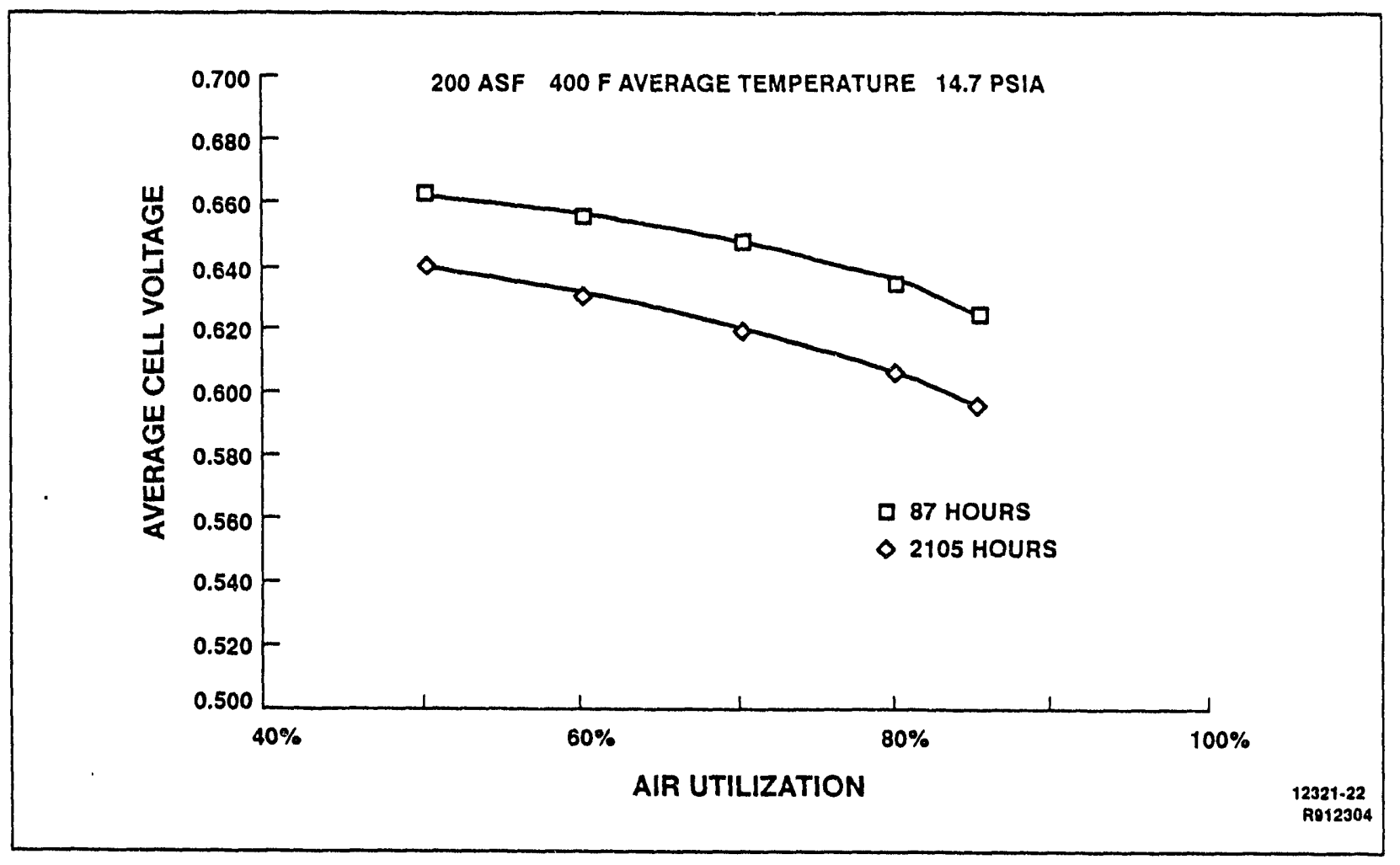

Figure 6.1-4. Air Utilization Sensitivity of the Small Area Development Stack

Individual cell voltage response to changes in cross pressure at $200 \mathrm{ASF}$, at 115 test hours, 832 test hours, 1925 test hours and 2197 test hours, are summarized in Figure 6.1-5. There were no signs of significant reactant cross leakage.

Cell package internal resistances at three different test hours, for both ISP cells and cooler cells, are compared in Figure 6.1-6.

Reactant gas cross leakage remained unchanged at approximately 0.8 percent of the rated fuel flow at 1 IWC.

Following ambient pressure testing, the stack electrolyte was conditioned to 87 percent concentration to provide additional freeze protection during transport and set up for pressurized operation. 


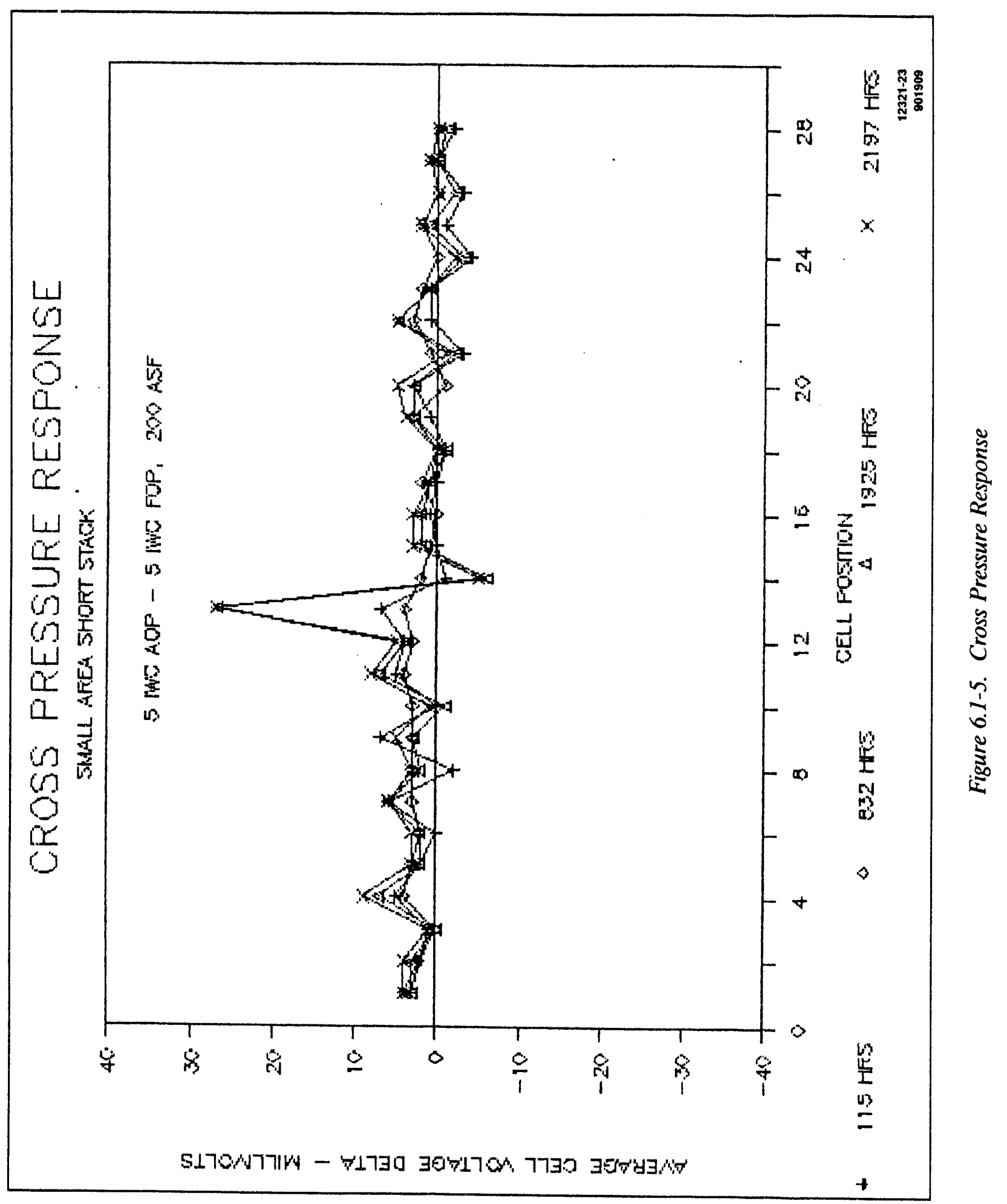




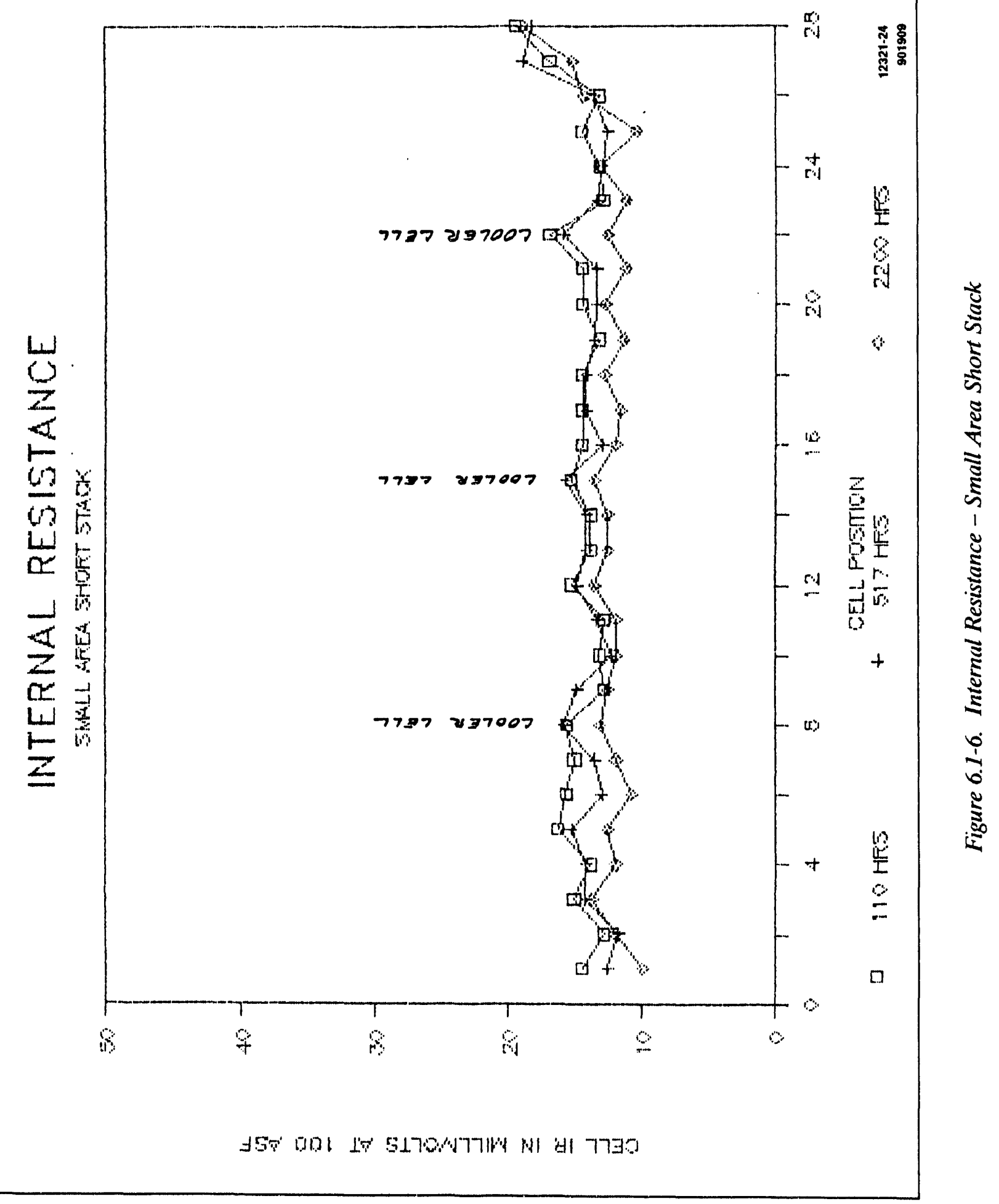


(2) Pressurized Testing

Pressurized testing was conducted during the Fall of 1990. Pressurized test time was 677 hours bringing the total test time to 3054 hours. A summary of pressurized test activities is shown in Table 6.1-2.

\begin{tabular}{|c|c|}
\hline \multicolumn{2}{|c|}{$\begin{array}{c}\text { Table 6.1-2 } \\
\text { Small Area Stack Test Activities }\end{array}$} \\
\hline $\begin{array}{l}\text { Test Time } \\
\text { (hours) }\end{array}$ & Pressurized Test Activity \\
\hline $\begin{array}{l}2378-2501 \\
2502-2597 \\
2598-2883 \\
2884-2910 \\
2911-3054\end{array}$ & $\begin{array}{l}\text { - } 200 \mathrm{ASF} \text { endurance } \\
\text { - } 300 \mathrm{ASF} \text { endurance } \\
\text { - } 200 \mathrm{ASF} \text { endurance } \\
\text { - } 300 \mathrm{ASF} \text { endurance } \\
\text { - } 200 \mathrm{ASF} \text { endurance } \\
\text { - Electrolyte conditioning }\end{array}$ \\
\hline
\end{tabular}

Nominal pressurized test conditions were 120 psia, 80 percent fuel utilization, 60 percent air utilization, and $400^{\circ} \mathrm{F}$ average cell temperature.

Figure 6.1-7 shows the average cell performance history at 200 ASF for substacks No. 2 and No. 3. (These two substacks are the most representative of full-size stack thermal profiles and nearly identical to the temperature-corrected average of the stack). The change in performance at 2400 hours of test time is a result of increasing pressure from 14.7 to 120 psia. The performance increase with pressurized operation was "as expected." The performance of all four substacks remained stable throughout the test. 


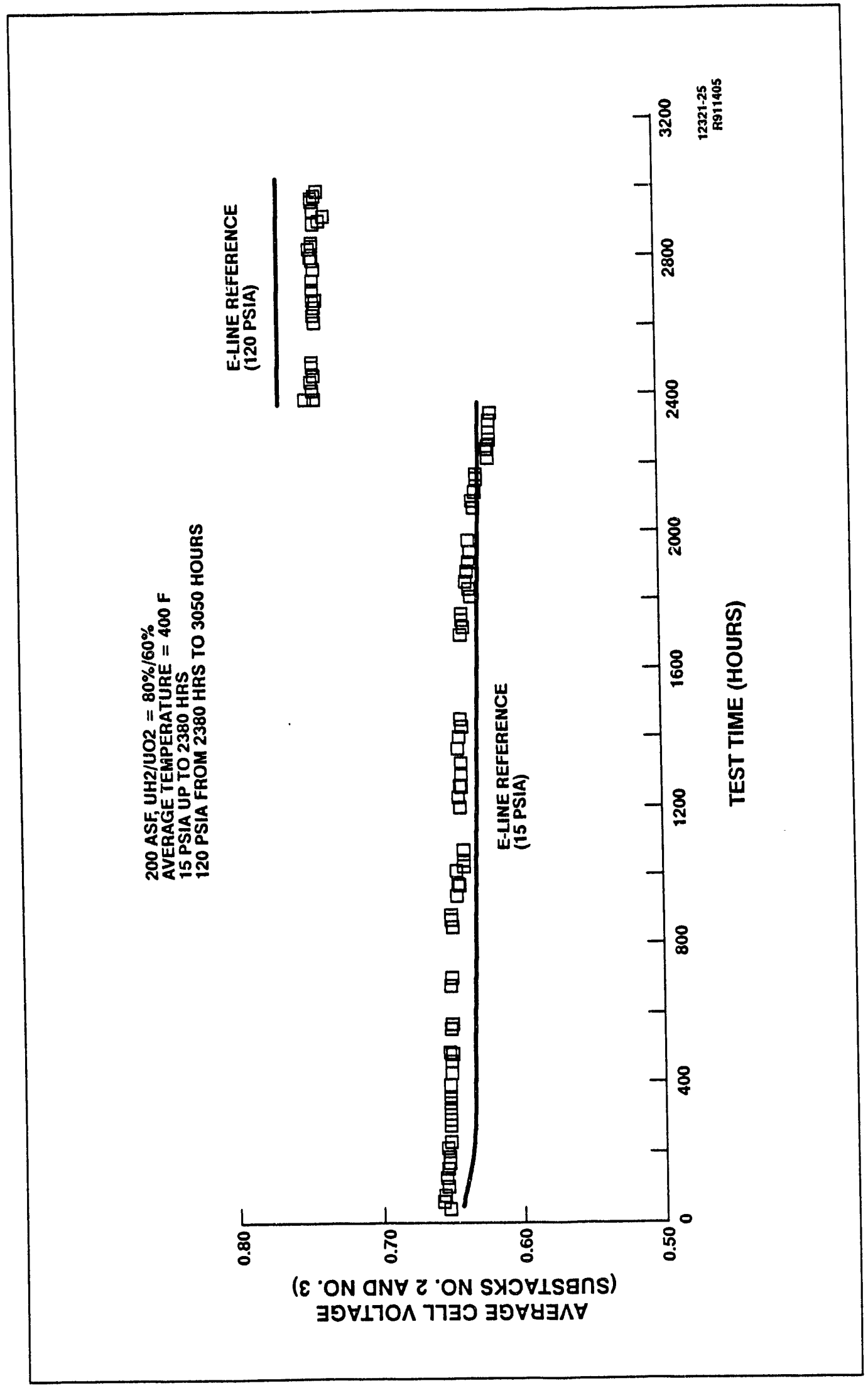

हิ 
(3) Post-Test Inspection

After successfully completing the ambient and pressurized tests, the stack was returned to the assembly floor for inspection.

Reactant overboard and crossover leakage was measured. The final leakage values are compared to the values measured after the initial thermal cycle, at the 2000 hour ambient pressure test inspection point, after air exit seal replacement and at the end of testing in Table 6.1-3. The data indicated overboard and crossover leakage was stable at ambient and pressurized conditions.

\begin{tabular}{|lcccc|}
\hline \multicolumn{4}{c|}{ Table 6.1-3. Reactant Leakage Summary } \\
\hline & $\begin{array}{c}\text { After } \\
\text { Thermal } \\
\text { Cycle }\end{array}$ & $\begin{array}{c}\text { Leakage in PPH } \mathbf{N}_{2} \text { at 8 IWC } \\
\text { Ambient }\end{array}$ & $\begin{array}{c}\text { Replaced } \\
\text { Air Exit } \\
\text { Seal }\end{array}$ & Final \\
\hline Overboard & 1.40 & 1.18 & 1.25 & 1.19 \\
Crossover & 6.29 & 5.91 & 6.91 & 7.01 \\
Hot Time & 50 Hours & 2200 Hours & 3000 Hours \\
\hline
\end{tabular}

The coolant system was leak tight during the post-test hydro test and was free of signs of any unusual contamination or other distress.

The final axial load was $21 \mathrm{psi}$, as compared to the pre-test load of 50 psi. See Figure $6.1-8$ for the axial load history. The axial load components were free of defects and the axial load electrical insulation features were unaffected by the testing, within the range of measurement.

Visual inspection showed all non-repeat parts were in excellent condition. Coolers were also in excellent condition with no evidence of corrosion, distress, or flow blockage. Cells were in good condition with the exception of minor burn streaks on three cells and some softness along cell edges. The softness is the result of corrosion during the pressurized test and will be minimized on the $10-\mathrm{ft}^{2}$ stack by edge treatments.

A thorough acid inventory analysis was conducted during the post-test inspection. As shown in Figure 6.1-9, there was little change in acid inventory and no indication of acid transfer over the test period. 


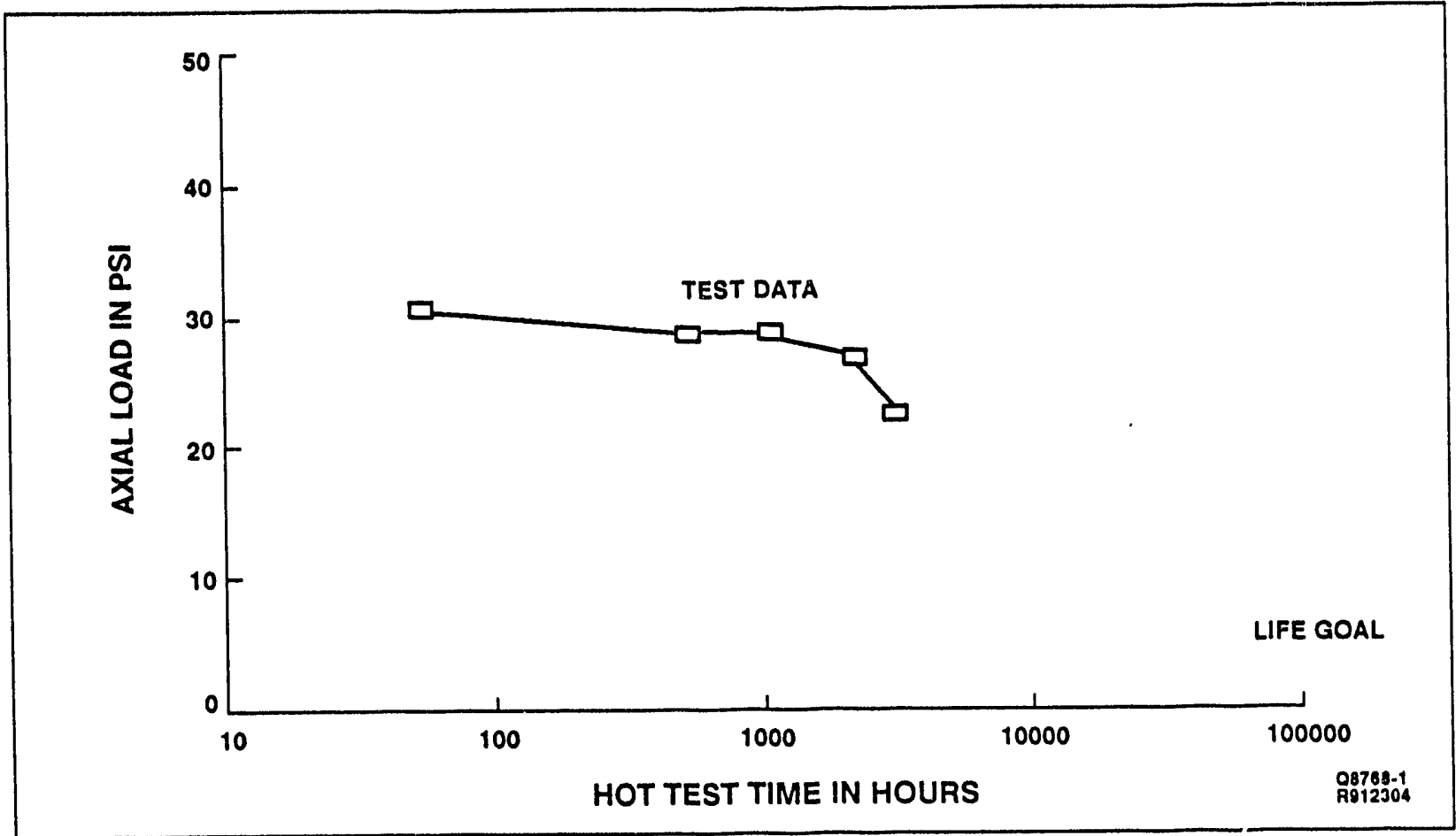

Figure 6.1-8. Small Area Development Stack Axial Load History

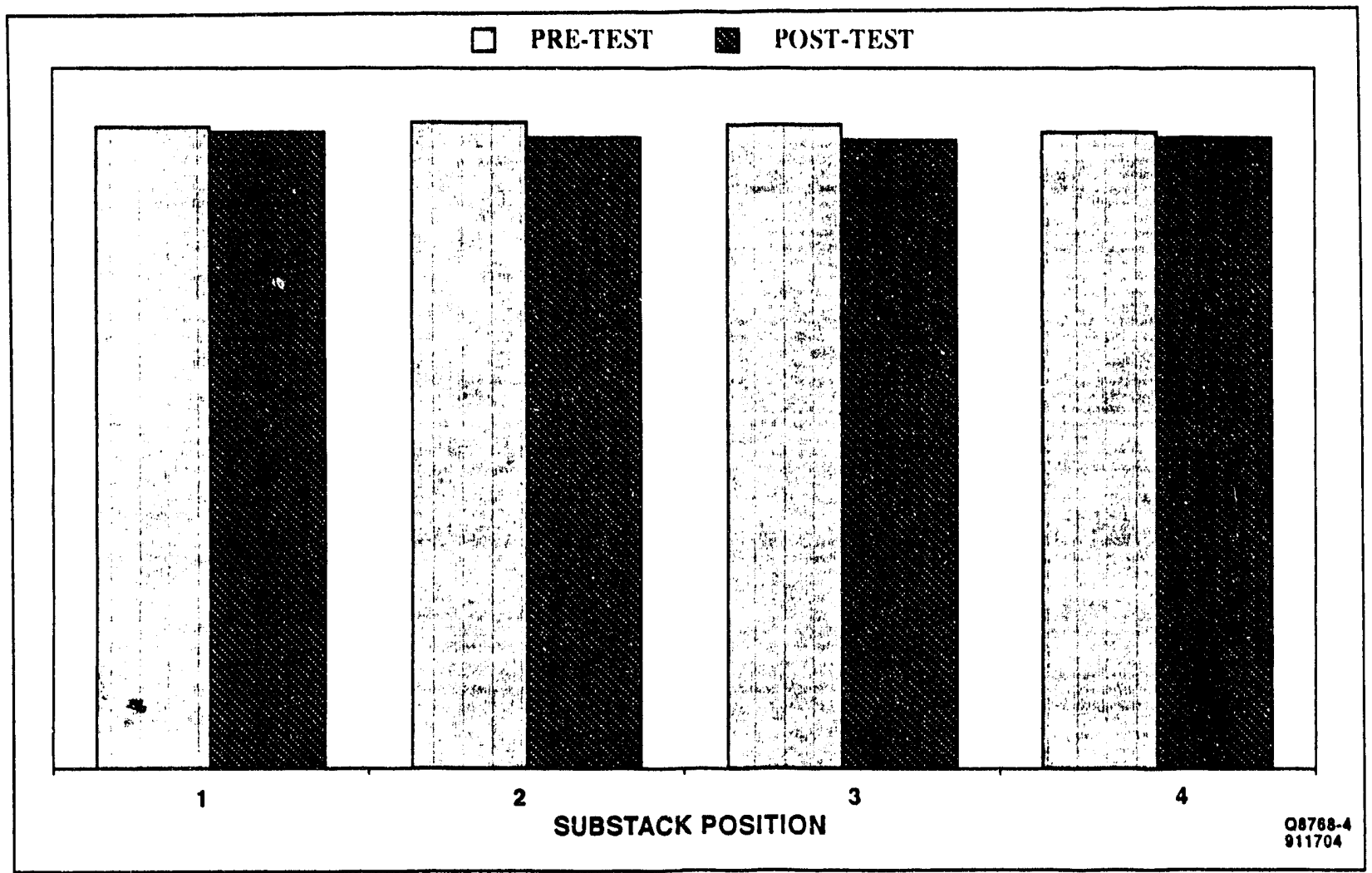

Figure 6.1-9. Acid Inventory of the Small Area Development Stack 


\section{Subtask 6.2 - Ten Square Foot Subscale Stack Test}

\section{Objective}

The objective of this task is to verify the scaleability of the Configuration-B cell design and evaluate the intermediate levels of achievement from Tasks 2.0 and 3.0.

\section{Summary}

Testing of the first $10-\mathrm{ft}^{2}$ subscale stack was successfully conducted for over 3000 -hours of load time. As shown in Figure 6.2-1, the stack exceeded the program power density goals of 175 WSF by producing $285 \mathrm{WSF}$ at . J0 ASF, but the performance at $400 \mathrm{ASF}$ was $40 \mathrm{mV}$ per cell below the conceptual design point. Further development is required to provide performance reproducibility at high power density with GSB-18P cathode catalyst.

\section{Activities}

(1) Test Preparations

In late 1990, test requirements were defined for the first $10-\mathrm{ft}^{2}$ stack test, and necessary test facility modifications to conduct the test were identified. Construction work was done to upgrade the test stand and facility for operation at current densities up to 400 ASF. Test stand functional checks were made after completing work to verify proper test stand operation.

A Test Readiness Review was also conducted to ensure the test stand, test stand support facilities, and procedures are properly prepared for successful completion of test objectives without endangering personnel, equipment, or the test article.

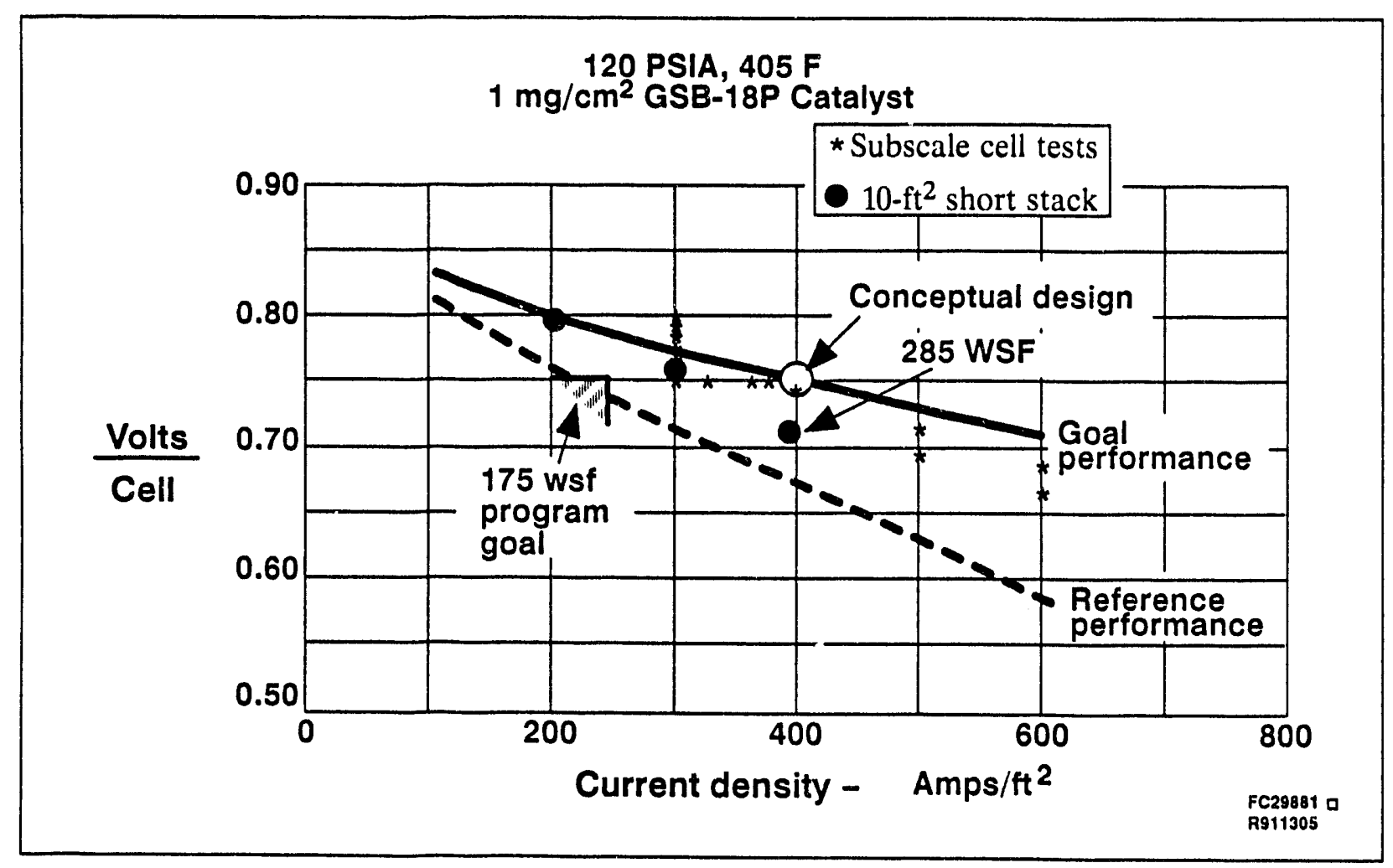

Figure 6.2-1. Average Cell Performance of the 10- $\mathrm{ft}^{2}$ Subscale Stack 
(2) Pressurized Testing

Testing of the stack was initiated in early March 1991. Total load time was 3051 hours. Thirteen thermal cycles were performed. A summary of test activities is listed in Table 6.2-1, and Figure 6.2-2 shows the stack time line.

Figure 6.2-3 shows the average cell performance history, and Figure 6.2-4 shows results of various performance calibrations. Performance remained generally stable with cells near coolers showing higher than desired response to changes in operating conditions and diagnostics. The cell-to-cell voltage profile is shown in Figure 6.2-5, and the response to various diagnostics is shown in Figure 6.2-6 through 6.2-8. Nominal pressurized test conditions were 120 psia, $80 \%$ fuel utilization, $70 \%$ air utilization, and approximately $400^{\circ} \mathrm{F}$ average cell temperature.

(3) Post-Test Inspections

The $10-\mathrm{ft}^{2}$ subscale stack was disassembled after completing post-test electrical isolation. reactant leakage, and coolant system hydrostatic tests. Unstacking was completed and the repeat parts were inspected and evaluated. Electrolyte concentration was stabilized to determine total electrolyte content.

Post-test electrical tests indicated no significant deterioration of the electrical isolation materials and components. Post-test reactant leakage measurements indicated only small increases in both overboard and crossover since the axial load was reset at 165 hours. The leakage log is shown in Table 6.2-2. Coolant system hydrotesting indicated no leaks in the manifolds, connecting hoses, and arrays. Axial load prior to teardown was $36.2 \mathrm{psi}$, as compared to the initial axial load of 50 psi. The stack was retorqued to $50 \mathrm{psi}$ at the 313 hour point. The axial load history is plotted in Figure 6.2-9. At teardown, all non-repeat components were in satisfactory condition for reuse without repair. All anode substrates were in excellent condition over the entire planform. Cathode substrates were in good condition, particularly in the active area. There was no discernable difference in the condition of the Vendor "A" thin electrode substrates and substrates formed for IFC. The laminated ERP's appeared to be in slightly better condition than the baseline ERP's formed on the double belt press. The coolers were in satisfactory condition with no indication of acid entry to the internal parts.

The strength of substrates from representative positions within the stack were determined. These measurements showed no reduction in strength over the total planform of the anode. The measurements also showed no significant reduction in strength over the active area of the cathode components.

Measurements of electrolyte transfer across the separator plates were made. There was no indication of any acid transfer within the active area of the cell. 


\begin{tabular}{|c|c|}
\hline $\begin{array}{l}\text { Load Time } \\
\text { (Hours) }\end{array}$ & Pressurized Test Activity \\
\hline $0-150$ & $\begin{array}{l}\text { Thermal Cycle } 1 \\
\text { - Cell break-in } \\
\text { - } 200 \mathrm{ASF} \\
\text { - Diagnostic tests }\end{array}$ \\
\hline $151-291$ & $\begin{array}{l}\text { Thermal Cycle } 2 \\
\text { - } 200 \text { ASF, } 300 \text { ASF, } 400 \text { ASF } \\
\text { - Diagnostic tests }\end{array}$ \\
\hline $292-317$ & $\begin{array}{l}\text { Thermal Cycle } 3 \\
\qquad 200 \text { ASF }\end{array}$ \\
\hline $318-817$ & $\begin{array}{l}\text { Thermal Cycle } 4 \\
\text { - } 200 \text { ASF, } 300 \text { ASF, } 400 \text { ASF } \\
\text { - Diagnostic tests }\end{array}$ \\
\hline $818-1375$ & $\begin{array}{l}\text { Thermal Cycle } 5 \\
\text { - } 200 \text { ASF, } 300 \text { ASF, } 400 \text { ASF } \\
\text { - Diagnostic tests }\end{array}$ \\
\hline $1376-1664$ & $\begin{array}{l}\text { Thermal Cycle } 6 \\
\text { - } 200 \text { ASF, } 300 \text { ASF }\end{array}$ \\
\hline $1665-1679$ & $\begin{array}{l}\text { Thermal Cycle } 7 \\
\bullet 300 \mathrm{ASF}\end{array}$ \\
\hline $1680-1820$ & $\begin{array}{c}\text { Thermal Cycle } 8 \\
\bullet 200 \mathrm{ASF}\end{array}$ \\
\hline $1821-2255$ & $\begin{array}{l}\text { Thermal Cycle } 9 \\
\bullet 200 \text { ASF, } 300 \text { ASF }\end{array}$ \\
\hline $2256-2294$ & $\begin{array}{l}\text { Thermal Cycle } 10 \\
\bullet 200 \text { ASF, } 300 \text { ASF }\end{array}$ \\
\hline $2295-2538$ & $\begin{array}{l}\text { Thermal Cycle } 11 \\
\bullet 200 \text { ASF, } 300 \text { ASF }\end{array}$ \\
\hline $2539-2658$ & $\begin{array}{l}\text { Thermal Cycle } 12 \\
\bullet 200 \text { ASF }\end{array}$ \\
\hline $2659-3051$ & $\begin{array}{l}\text { Thermal Cycle } 13 \\
\text { - } 200 \text { ASF, } 300 \text { ASF, } 400 \text { ASF } \\
\text { - Stack Conditioning }\end{array}$ \\
\hline
\end{tabular}




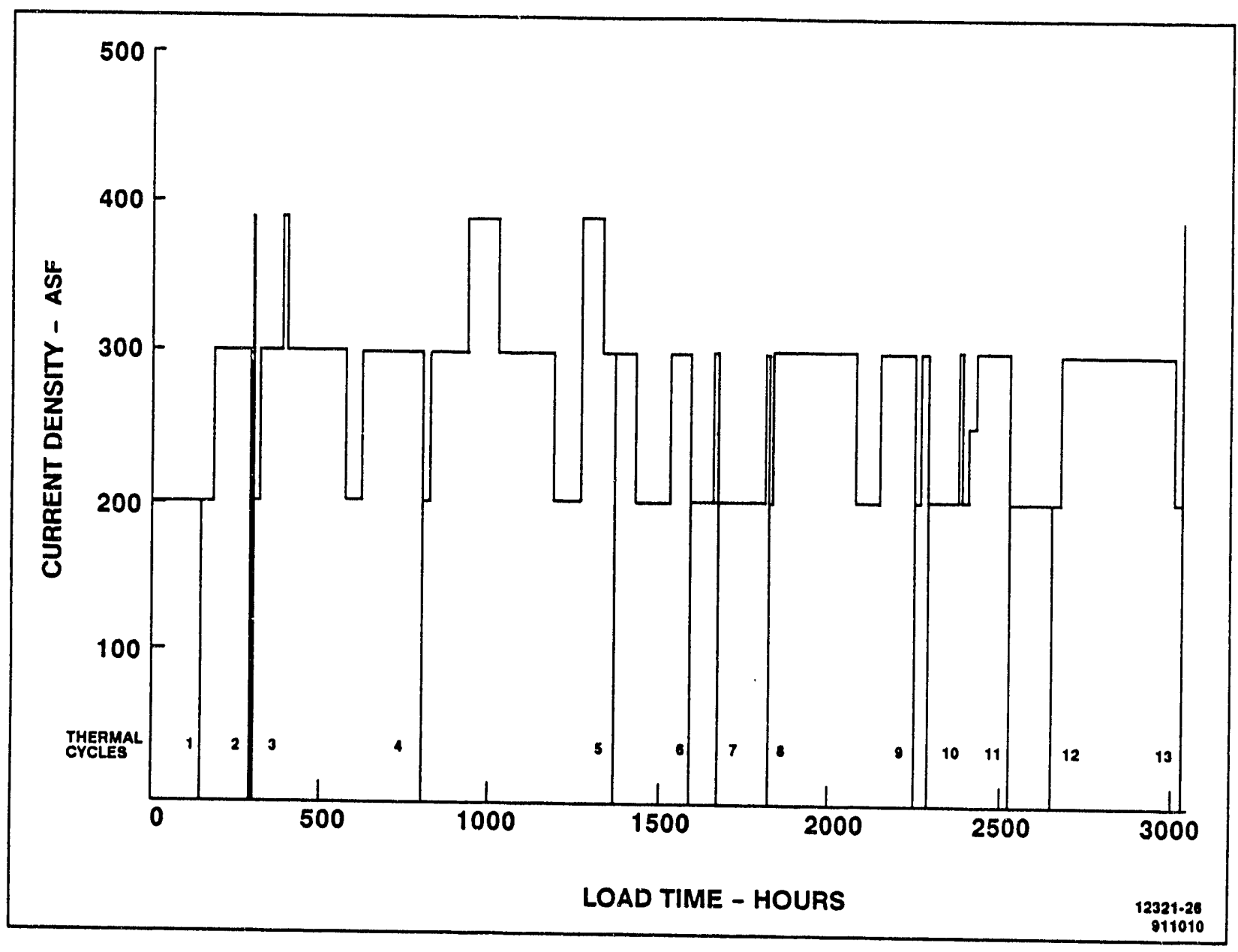

Figure 6.2-2. METC 10-ft ${ }^{2}$ Short Stack Time Line, March - September, 1991 


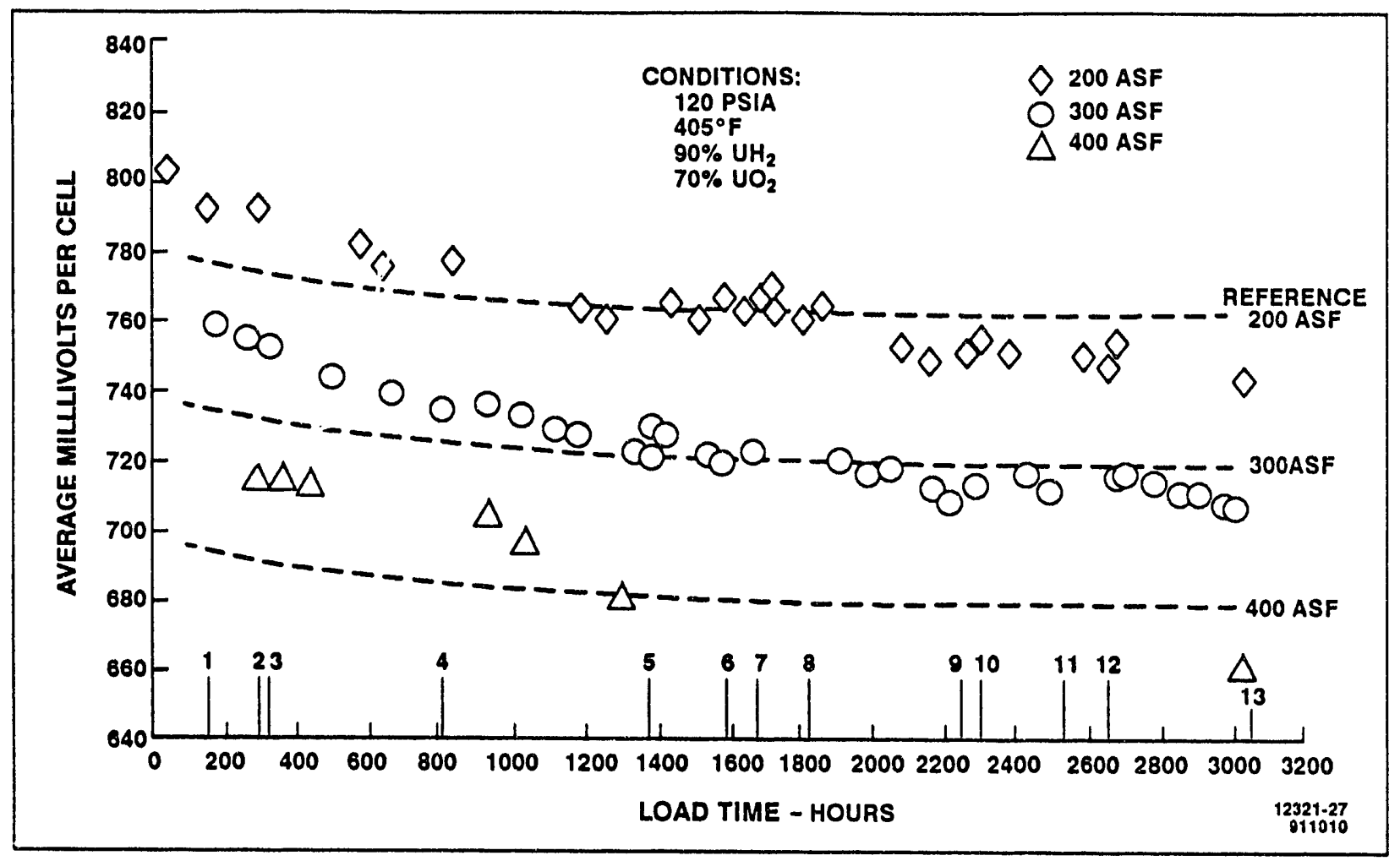

Figure 6.2-3. 10-Ft ${ }^{2}$ Short Stack

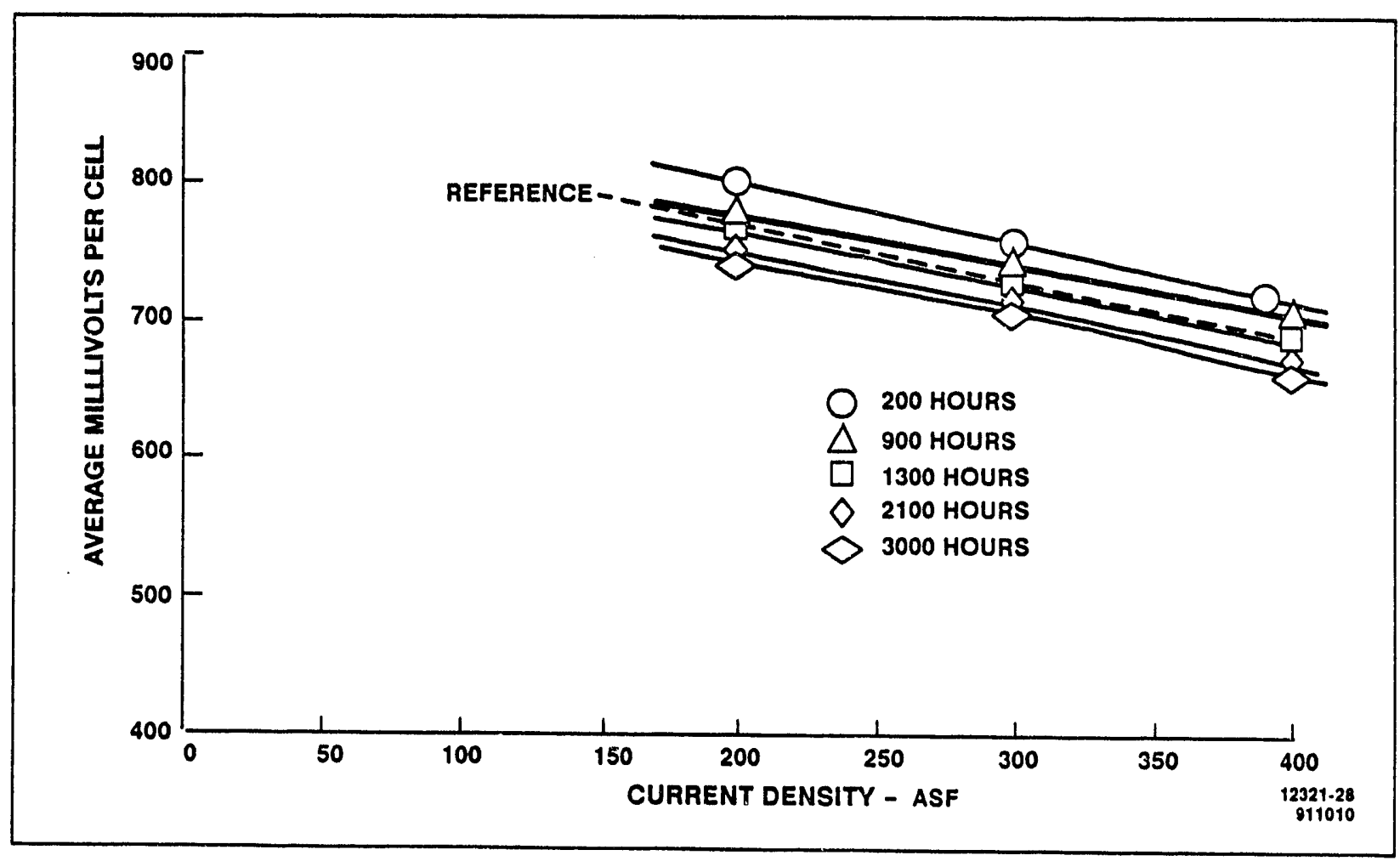

Figure 6.2-4. METC 10-Ft ${ }^{2}$ Short Stack 


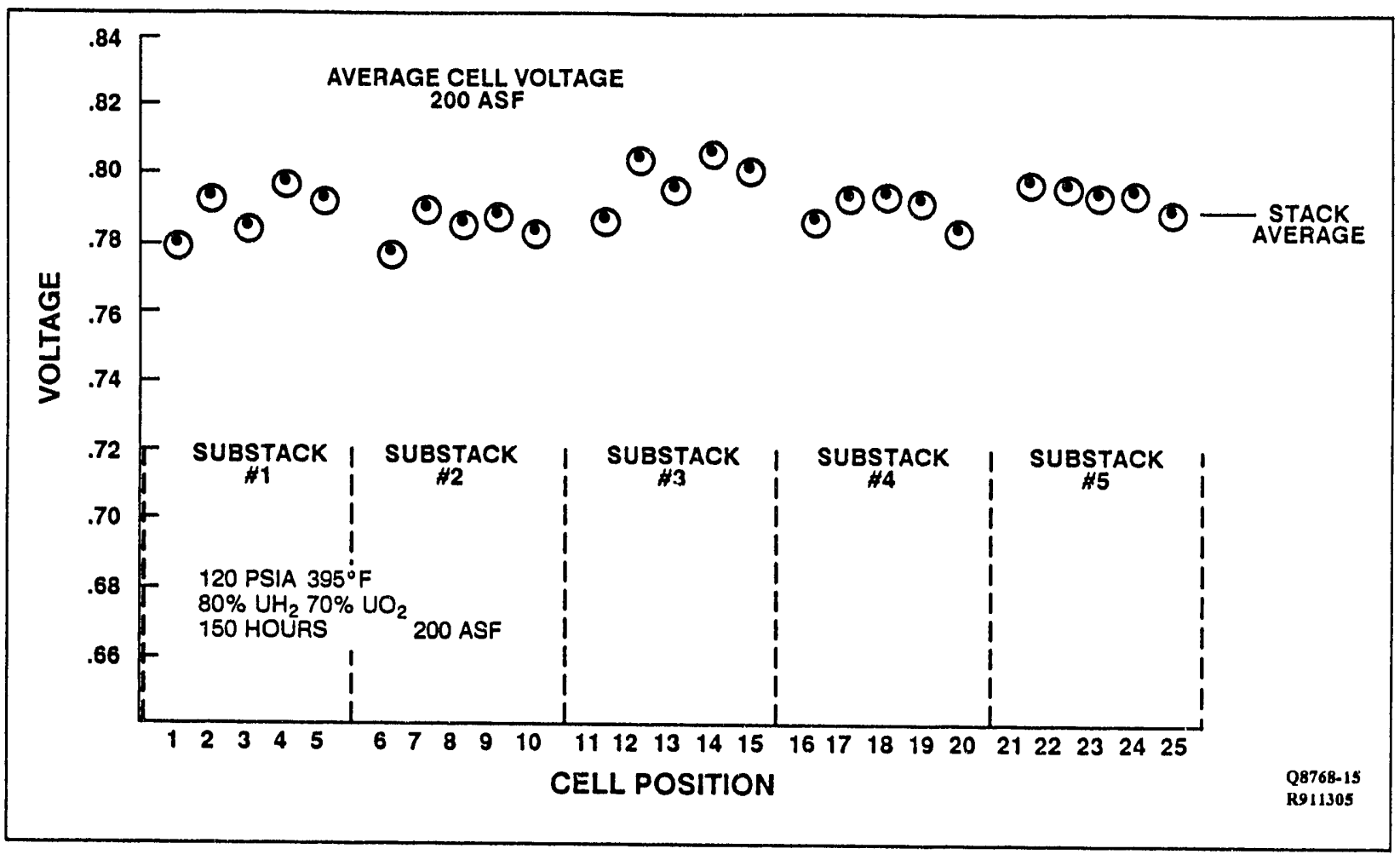

Figure 6.2-5. 10-Ft ${ }^{2}$ Subscale Stack Cell Performance at 200 ASF

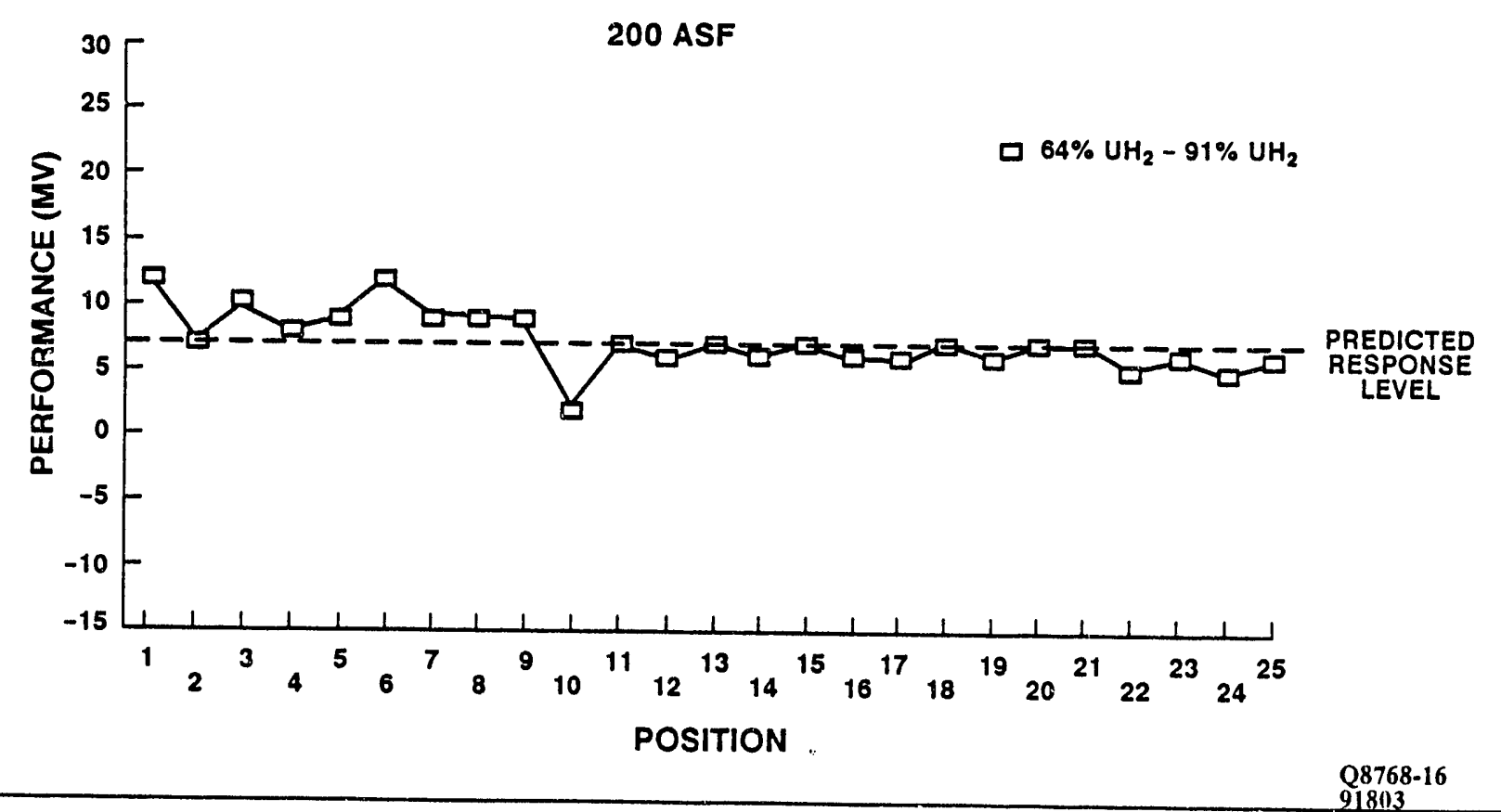

Figure 6.2-6. Fuel Utilization Response of the 10-ft ${ }^{2}$ Subscale Stack 


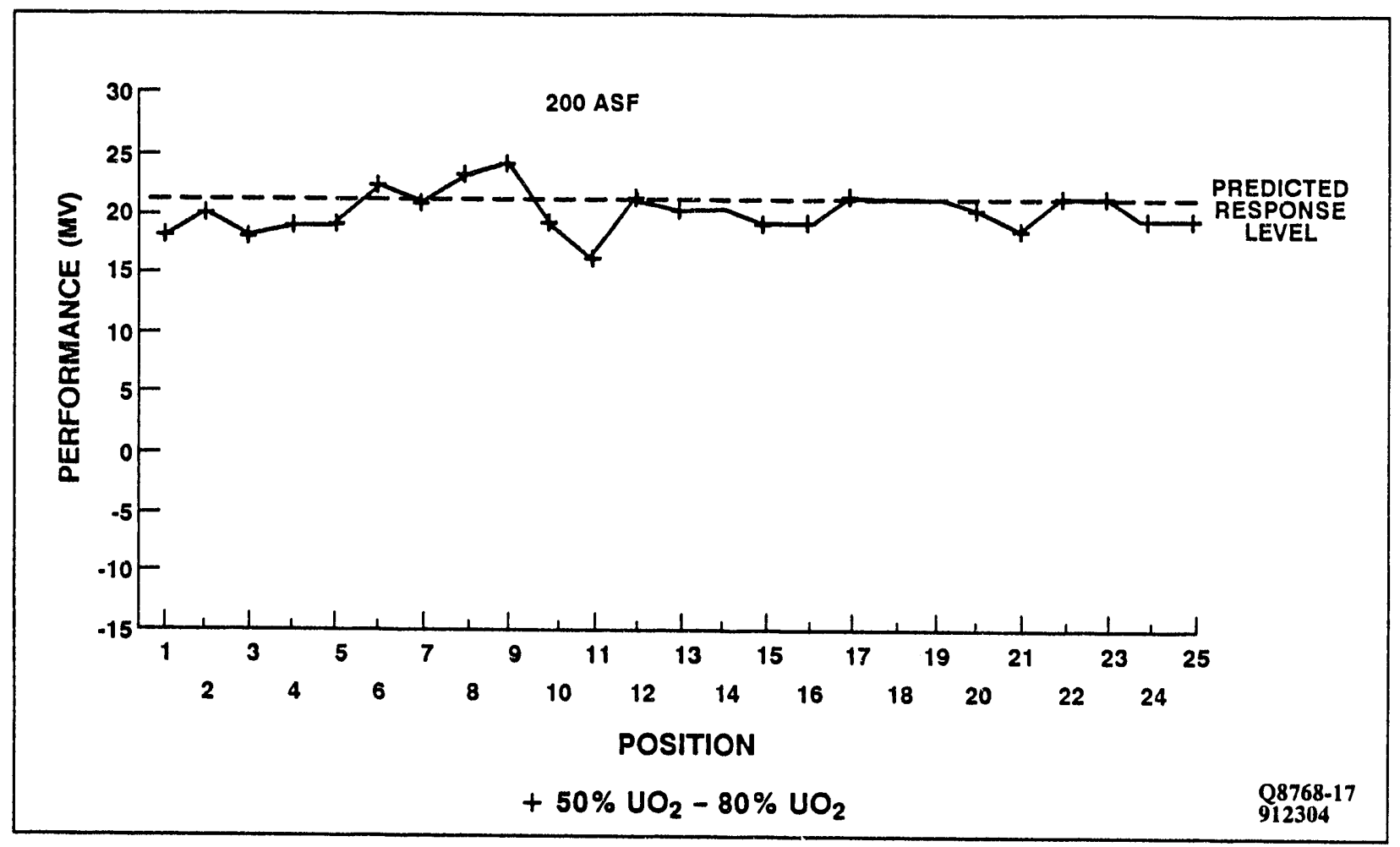

Figure 6.2-7. METC 10-ft ${ }^{2}$ Short Stack Average Air Util. Response

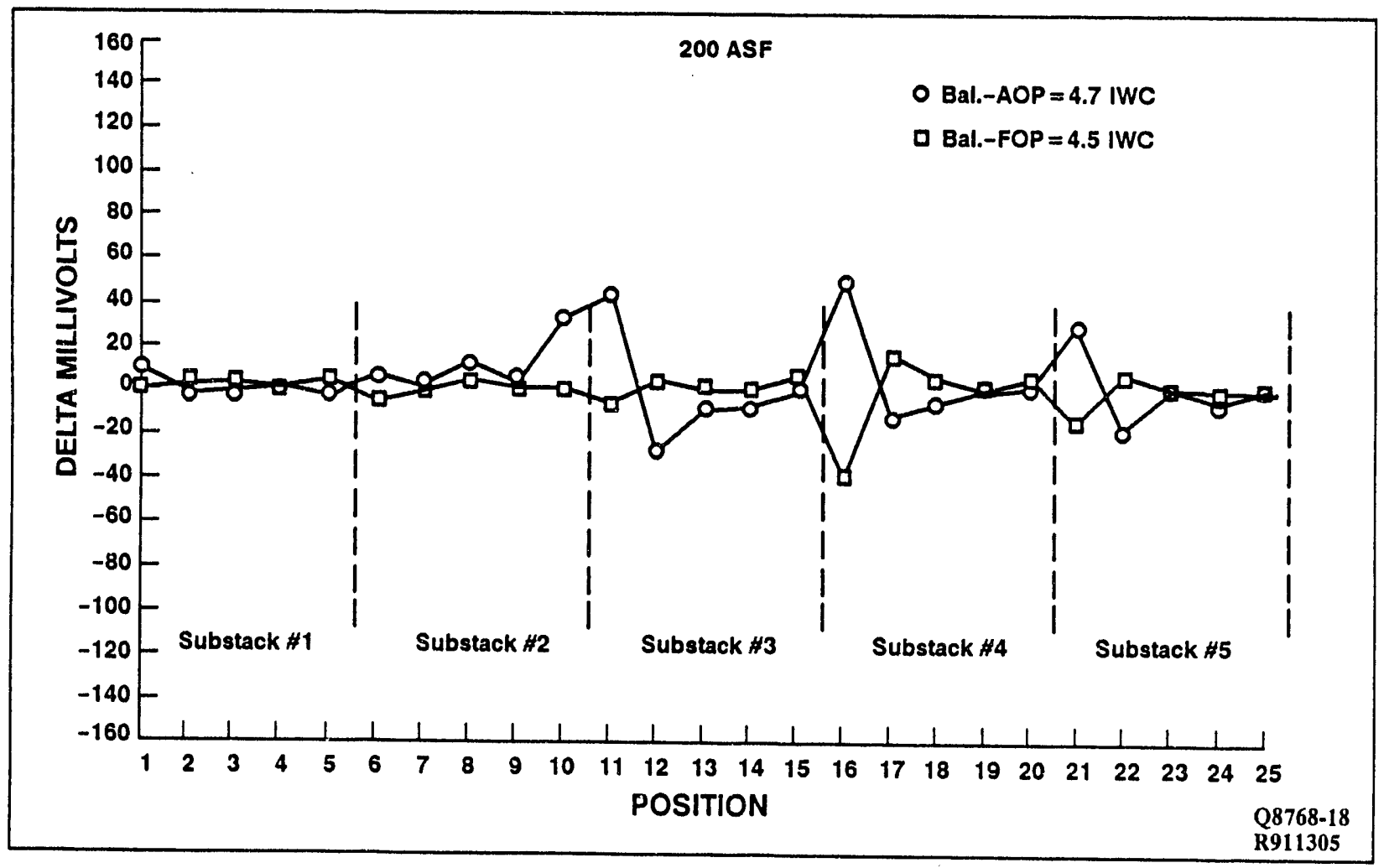

Figure 6.2-8. Average Cross Pressure Response of the 10- $f t^{2}$ Subscale Stack 


\begin{tabular}{|lcc|}
\hline \multicolumn{3}{|c|}{$\begin{array}{c}\text { Table 6.2-2. Reactant Leakage History } \\
\text { Leakage in PPH } \mathbf{N}_{\mathbf{2}} \text { at } \mathbf{8} \text { iwc }\end{array}$} \\
\hline Condition & Crossover & Ovbscale Stack \\
\hline Initial & 1.81 & 0.99 \\
After 1st Thermal Cycle @ 165 Hours & 4.97 & 1.41 \\
After 2nd Thermal @ 313 Hours & & \\
- As-Is & 4.98 & 0.76 \\
- Reset 50 psi Axial Load & 3.24 & 0.70 \\
Final & 3.66 & 1.14 \\
\hline
\end{tabular}

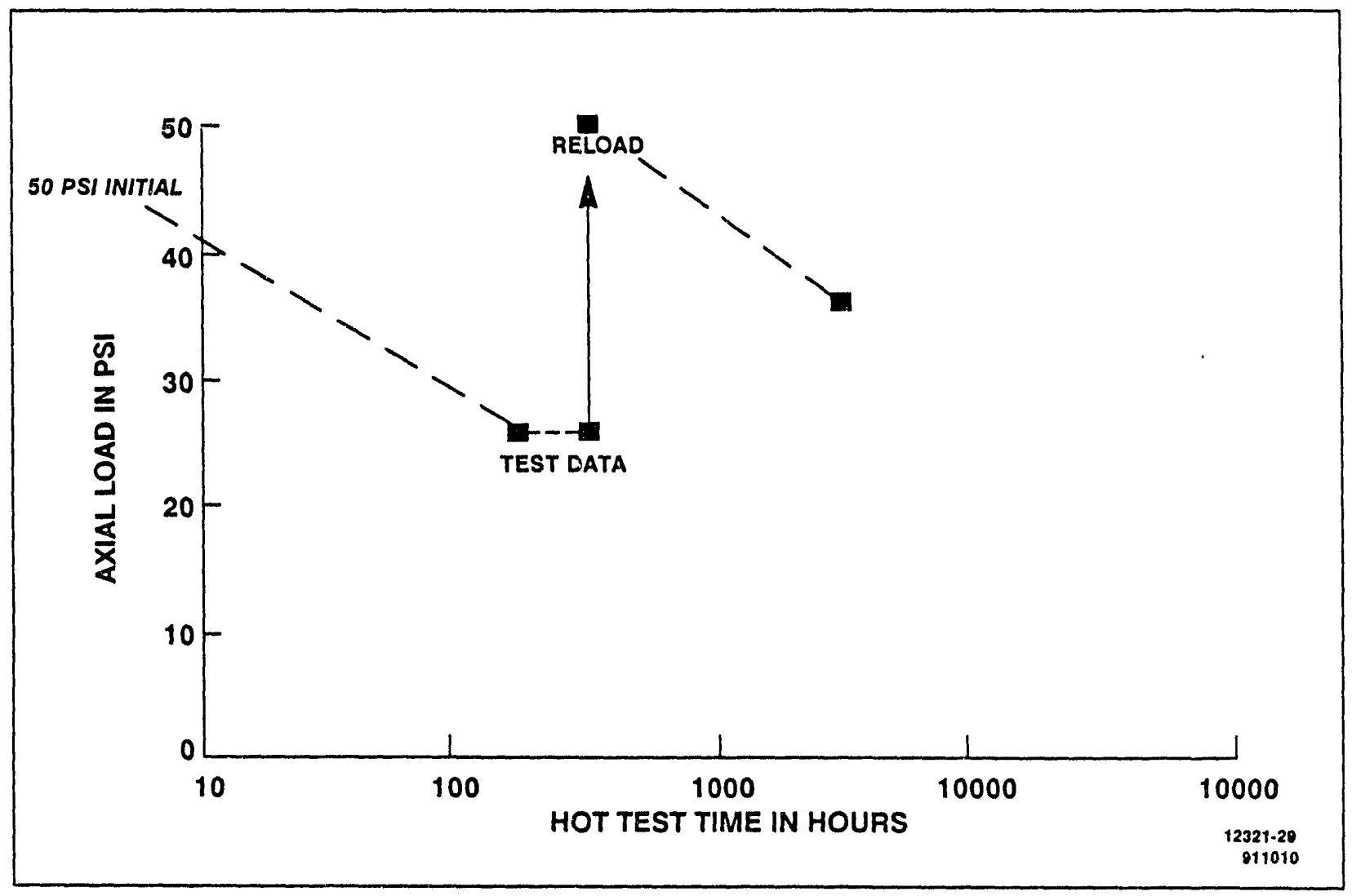

Figure 6.2-9. Axial Load History - 1st 10-Ft ${ }^{2}$ Subscale Stack 


\section{Subtask 6.3 - On-site Small Area Stack Test}

\section{Objective}

The objective of this task is to provide technology verification by operating a Configuration-B on-site short stack for an extended period of time.

\section{Summary}

The small area on-site stack contained 32-cells with coolers spaced every eight cells and included processing changes intended to improve seal integrity and performance stability. The stack was successfully tested at on-site operating conditions for over 4500 -hours with a decay rate less than $4 \mathrm{mV}$ per 1000 hours. See Figure 6.3-1.

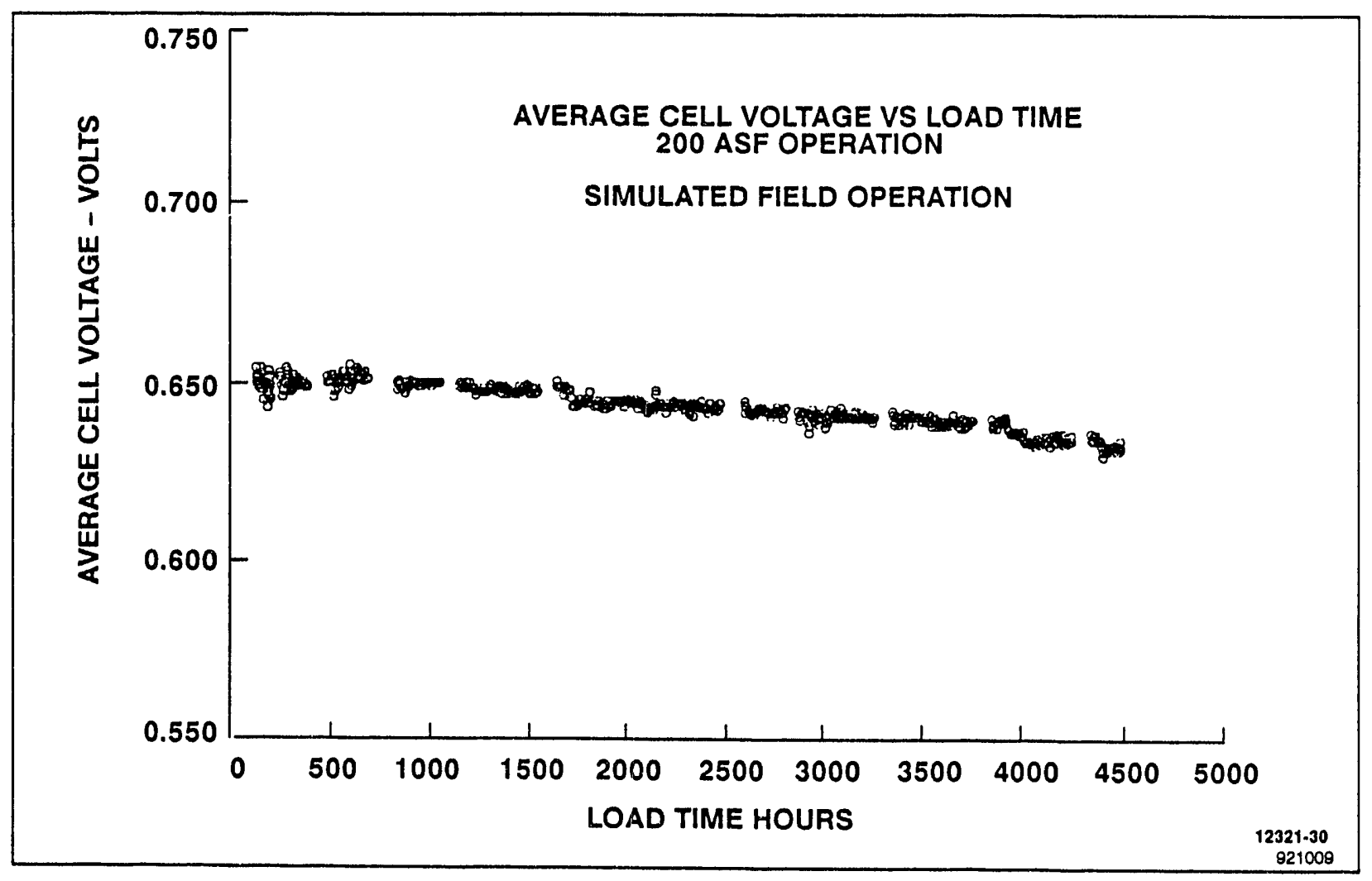

Figure 6.3-1. Small Area On-Site Short Stack Performance History

\section{Discussion of Activities}

(1) Test Preparations

Test stand functional checks of pressure, temperature, flow control and instrumentation systems were completed prior to test initiation. A Test Readiness Review was conducted to ensure that the test stand, test facilities, and procedures were adequate and properly prepared to achieve the successful completion of testing without endangering personnel, equipment or the test article.

(2) Stack Testing

Stack testing was initiated in the winter of 1992 . Thirteen (13) load cycles were performed. A summary of test activities is shown in Table 6.3-1.

The test plan and test conditions simulate typical on-site cell stack operation. At rated power, operating conditions are set to 80 percent fuel utilization, 60 percent air utilization and approximately $400^{\circ} \mathrm{F}$ average cell temperature. 


\begin{tabular}{|c|c|}
\hline $\begin{array}{l}\text { Load Time } \\
\text { (Hours) }\end{array}$ & Test Activity \\
\hline $0-7$ & $\begin{array}{l}\text { Load Cycle } 1 \text { - Cell Acceptance Test Simulation } \\
\text { - Cell break-in } \\
\bullet 50 \text { ASF, } 100 \text { ASF }\end{array}$ \\
\hline 7.37 & $\begin{array}{l}\text { Load Cycle } 2 \text { - Cell Stack Acceptance Test Simulation (continued) } \\
\qquad 50 \text { ASF, 100ASF, 200ASF } \\
\text { - Diagnostic tests }\end{array}$ \\
\hline $37-57$ & $\begin{array}{c}\text { Load Cycle } 3 \text { - Power Plant Acceptance Test Simulation } \\
\qquad 50 \mathrm{ASF}, 100 \mathrm{ASF}, 150 \mathrm{ASF}, 200 \mathrm{ASF}\end{array}$ \\
\hline $57-97$ & $\begin{array}{r}\text { Load Cycle } 4 \text { - Power Plant Shipment Simulation } \\
\bullet \text { Electrolyte Concentration Reduction }\end{array}$ \\
\hline $97-152$ & $\begin{array}{c}\text { Load Cycle } 5 \text { - Simulated Power Plant Field Operation } \\
\qquad 50 \text { ASF, } 100 \text { ASF, } 200 \text { ASF }\end{array}$ \\
\hline $152-1715$ & $\begin{array}{l}\text { Load Cycle } 6 \text { - Simulated Power Plant Field Operation } \\
\text { - } 50 \text { ASF, } 100 \text { ASF, } 200 \text { ASF } \\
\text { - Diagnostic tests }\end{array}$ \\
\hline $1715 \cdot 2147$ & $\begin{array}{c}\text { Load Cycle } 7 \text { - Simulated Power Plant Field Operation } \\
\qquad 50 \text { ASF, } 100 \text { ASF, } 200 \text { ASF }\end{array}$ \\
\hline $2147-2858$ & $\begin{array}{c}\text { Load Cycle } 8 \text { - Simulated Power Plant Field Operation } \\
\qquad 50 \mathrm{ASF}, 100 \mathrm{ASF}, 200 \mathrm{ASF}\end{array}$ \\
\hline 2858-3932 & $\begin{aligned} & \text { Load Cycle } 9 \text { - Simulated Power Plant Field Operation } \\
& \text { - } 50 \text { ASF, } 100 \text { ASF, } 200 \text { ASF } \\
& \text { - Diagnostic Tests } \\
& \text { - Scheduled Shutdown } \\
& \text { for Plant Maintenance }\end{aligned}$ \\
\hline
\end{tabular}




\begin{tabular}{|c|c|}
\hline $\begin{array}{l}\text { Load Time } \\
\text { (Hours) }\end{array}$ & Test Activity \\
\hline $3932-3958$ & $\begin{aligned} \text { Load Cycle } & 10-\text { Simulated Power Plant Field Operation } \\
& -200 \text { ASF } \\
& - \text { Repair Test Facility Reactant Leak }\end{aligned}$ \\
\hline $3958-4379$ & $\begin{array}{c}\text { Load Cycle } 11 \text { - Simulated Power Plant Field Operation } \\
\bullet 50 \text { ASF, } 100 \text { ASF, } 200 \text { ASF }\end{array}$ \\
\hline $4379-4396$ & $\begin{aligned} \text { Load Cycle } & 12-\text { Simulated Power Plant Field Operation } \\
& \bullet 200 \mathrm{ASF} \\
& \bullet \text { Diagnostic Tests }\end{aligned}$ \\
\hline 4396-Present & $\begin{aligned} \text { Load Cycle } & 13 \text { - Simulated Power Plant Field Operation } \\
& -50 \mathrm{ASF}, 100 \mathrm{ASF}, 200 \mathrm{ASF} \\
& - \text { Diagnostic Tests }\end{aligned}$ \\
\hline
\end{tabular}

During load cycle 1,2 , and 3 , factory acceptance tests for a cell stack and a power plant were simulated. Stack performance was as expected. The stack was shutdown and its electrolyte conditioned as though it were to be shipped.

Simulated power plant field operations were then begun and continued throughout for the remainder of testing. As shown in Figure 6.3-2, field operation was simulated by running a two-week cycle that varied load between $50 \mathrm{ASF}$ and $200 \mathrm{ASF}$.

Performance of the stack remained stable and uniform. Figure 6.3-3 shows the results of performance calibrations, and Figure 6.3-4 shows the cell-to-cell voltage variation at the $200 \mathrm{ASF}$ rating. The average stack voltage at $200 \mathrm{ASF}$ was 0.652 -volts at the beginning of simulated field operating and 0.636 -volts at the end of testing. The average decay was therefore $3.6 \mathrm{mV}$ per 1000 -hours. 


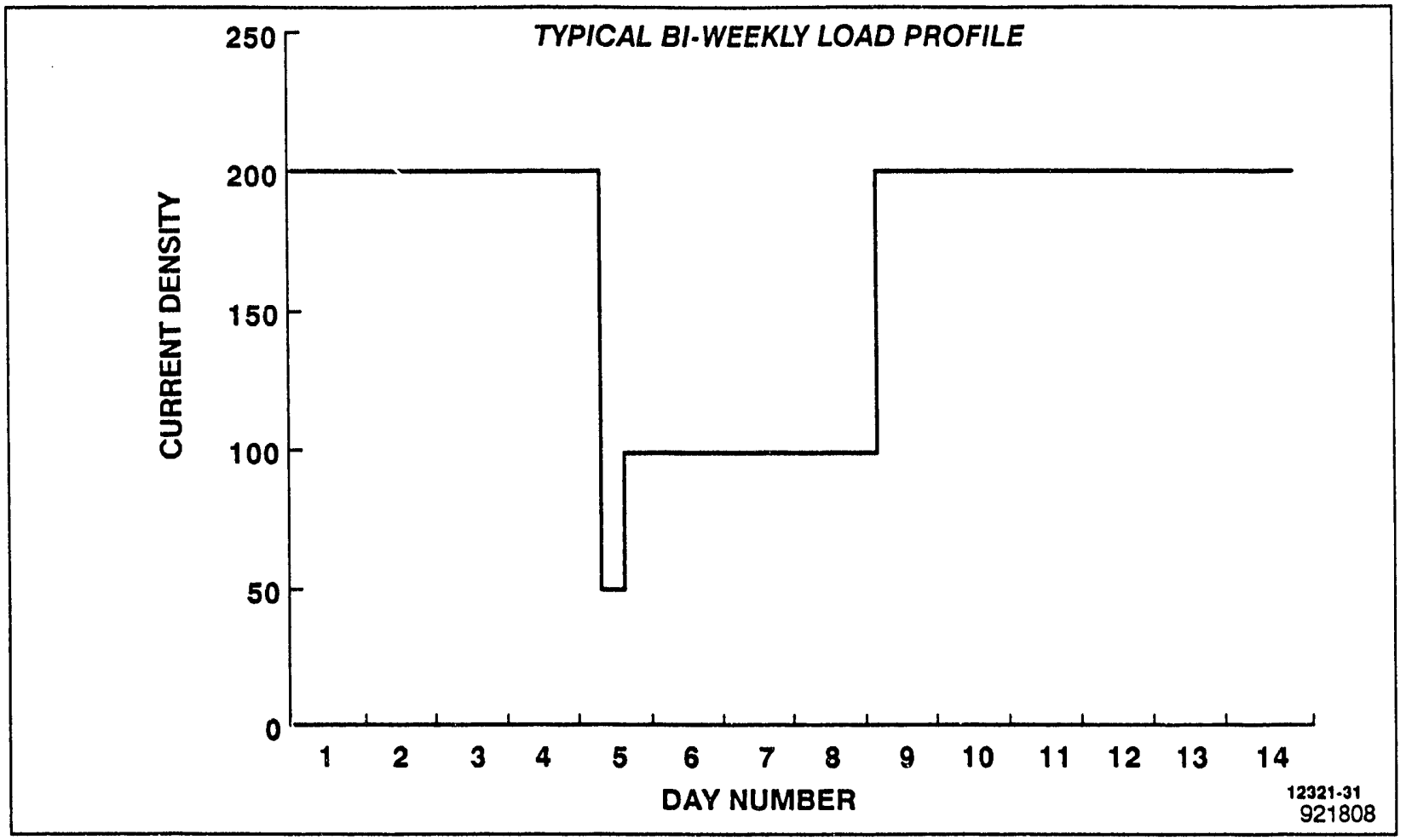

Figure 6.3-2. METC On-Site Small Area

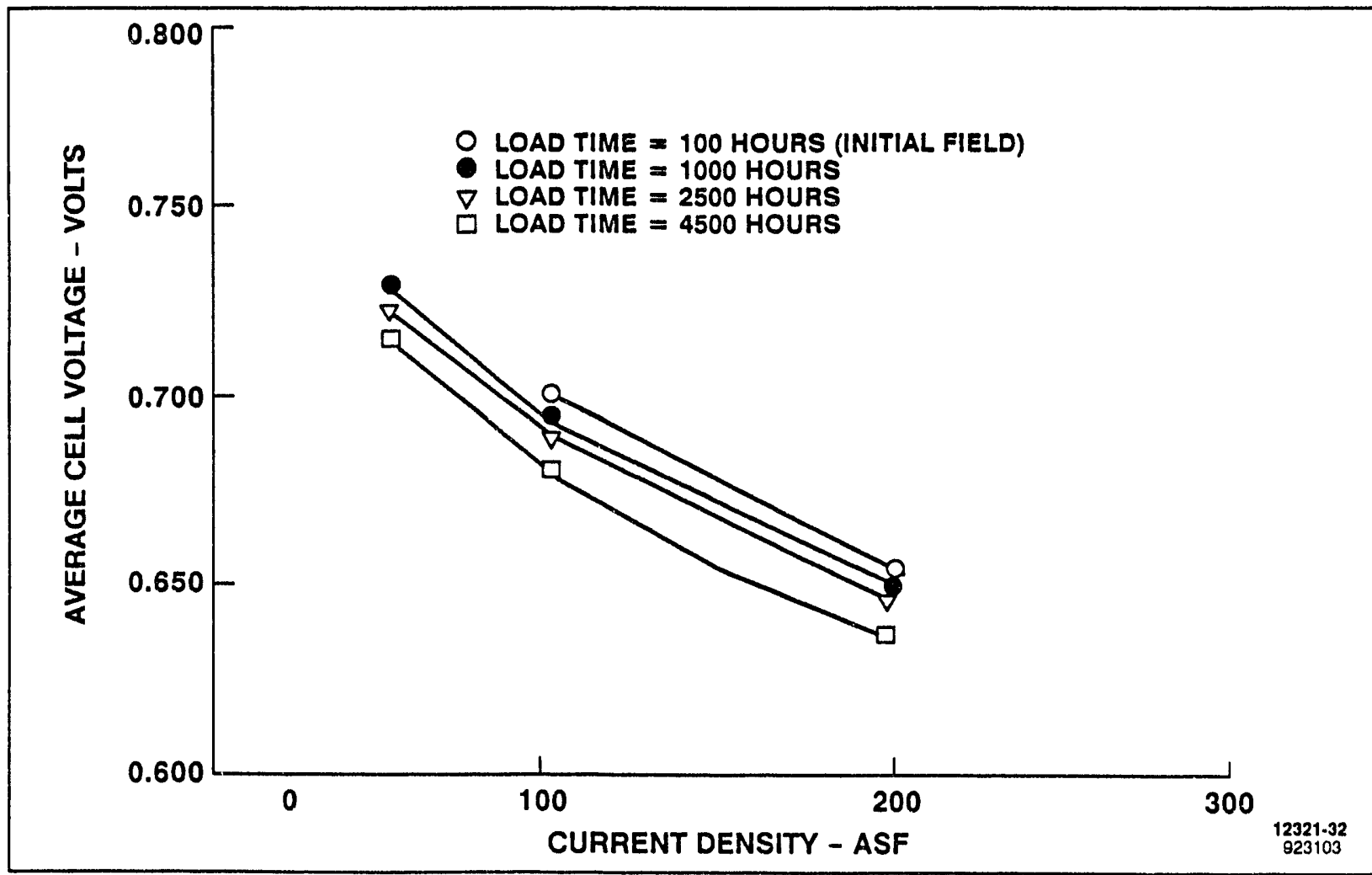

Figure 6.3-3. METC On-Site Small Area Stack - Performance Calibration 


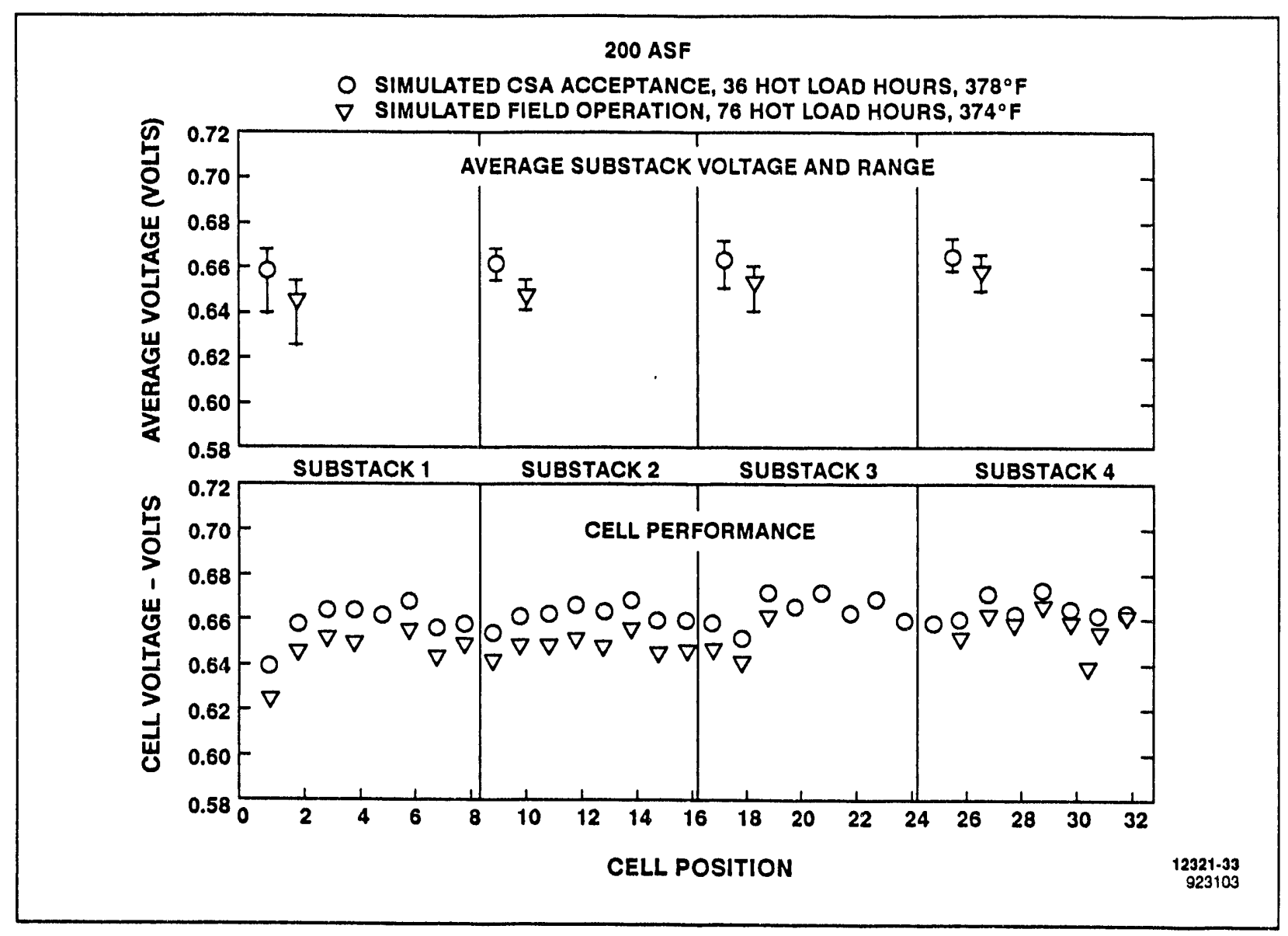

Figure 6.3-4. METC On-Site Small Area Stack - Cell and Average Substack Performance

Diagnostic tests were periodically performed on the cell stack throughout the testing. The responses to fuel and air utilization are shown in Figures 6.3-5 and 6.3-6 for various operating times, and the results of cell iR measurements and reactant cross pressure sensitivity and hydrogen gain are shown in Figures $6.3-7,6.3-8$, and 6.3-9, respectively. 


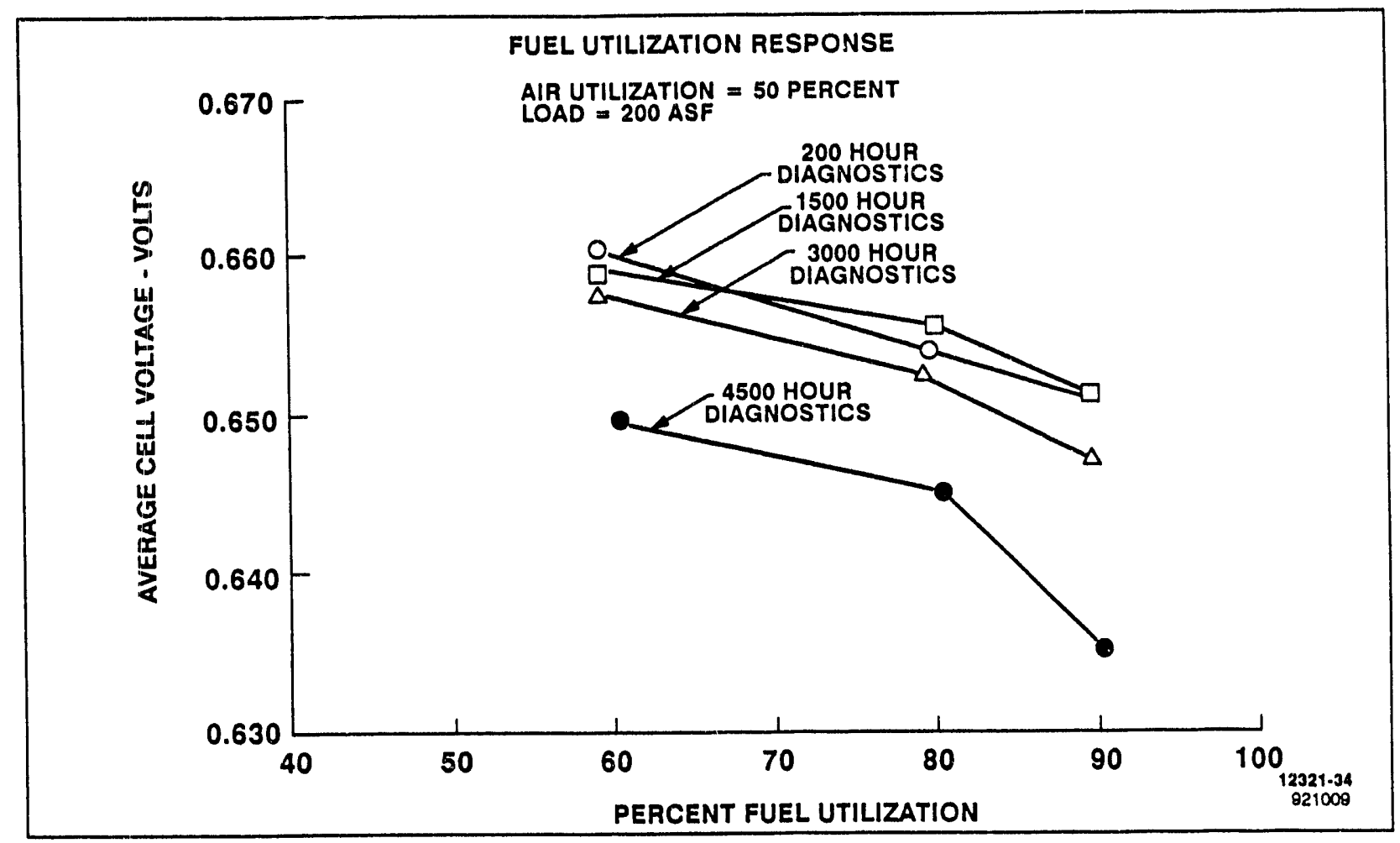

Figure 6.3-5. METC Small Area On-Site Short Stack Fuel Utilization Sensitivity

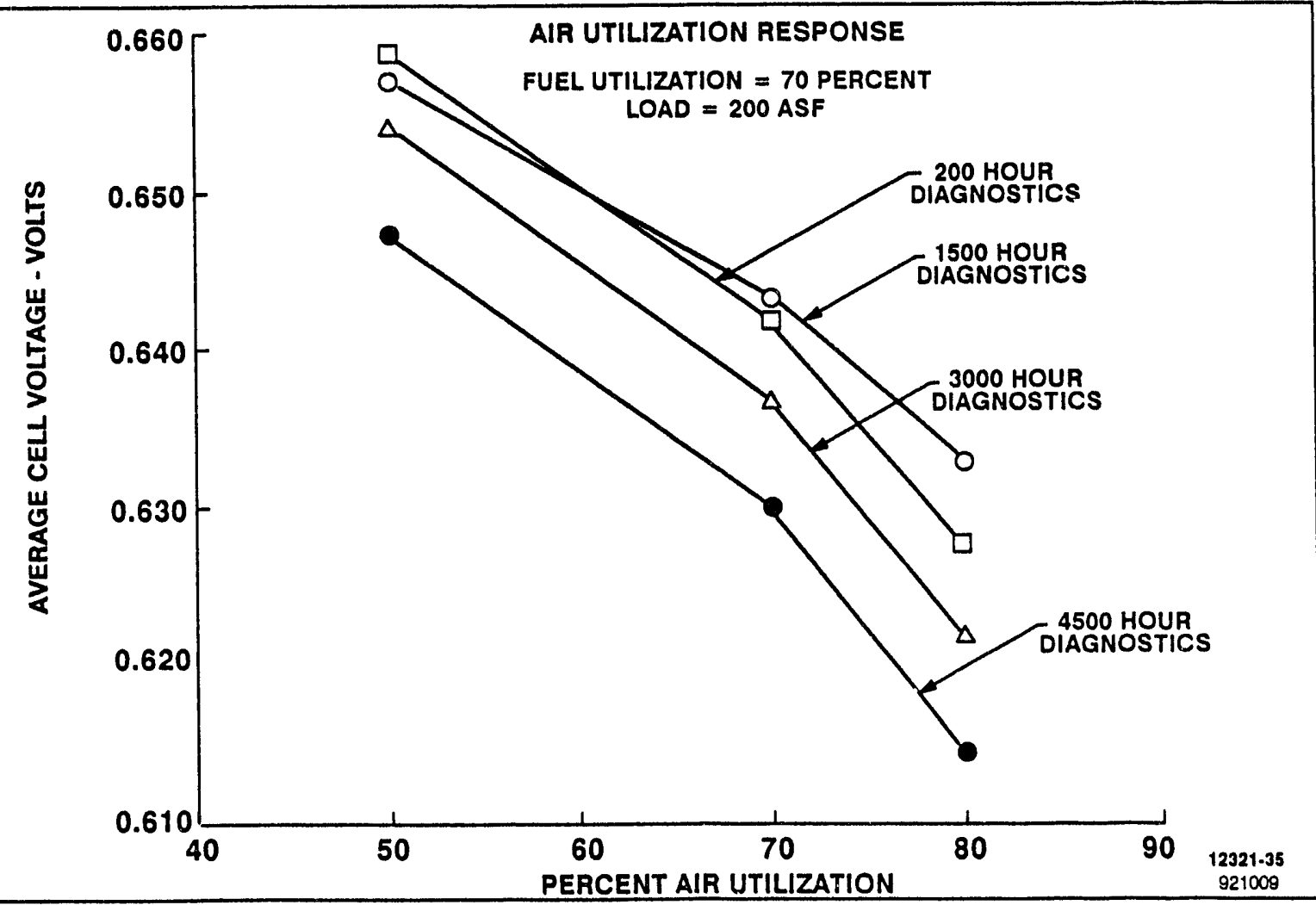

Figure 6.3-6. METC Small Area On-Site Short Stack Air Utilization Sensitivity 


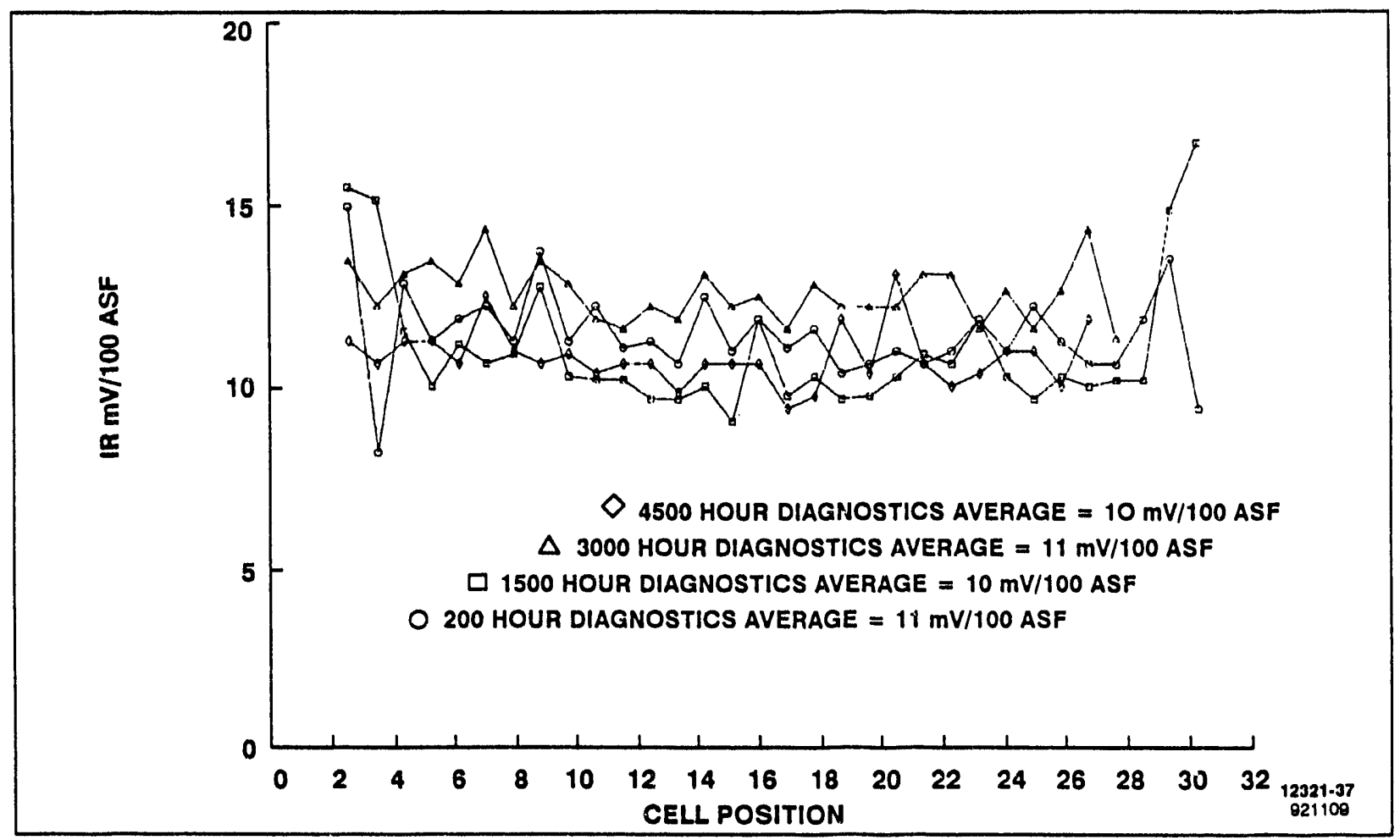

Figure 6.3-7. METC Small Area On-Site Short Stack Individual Cell iR Measurements

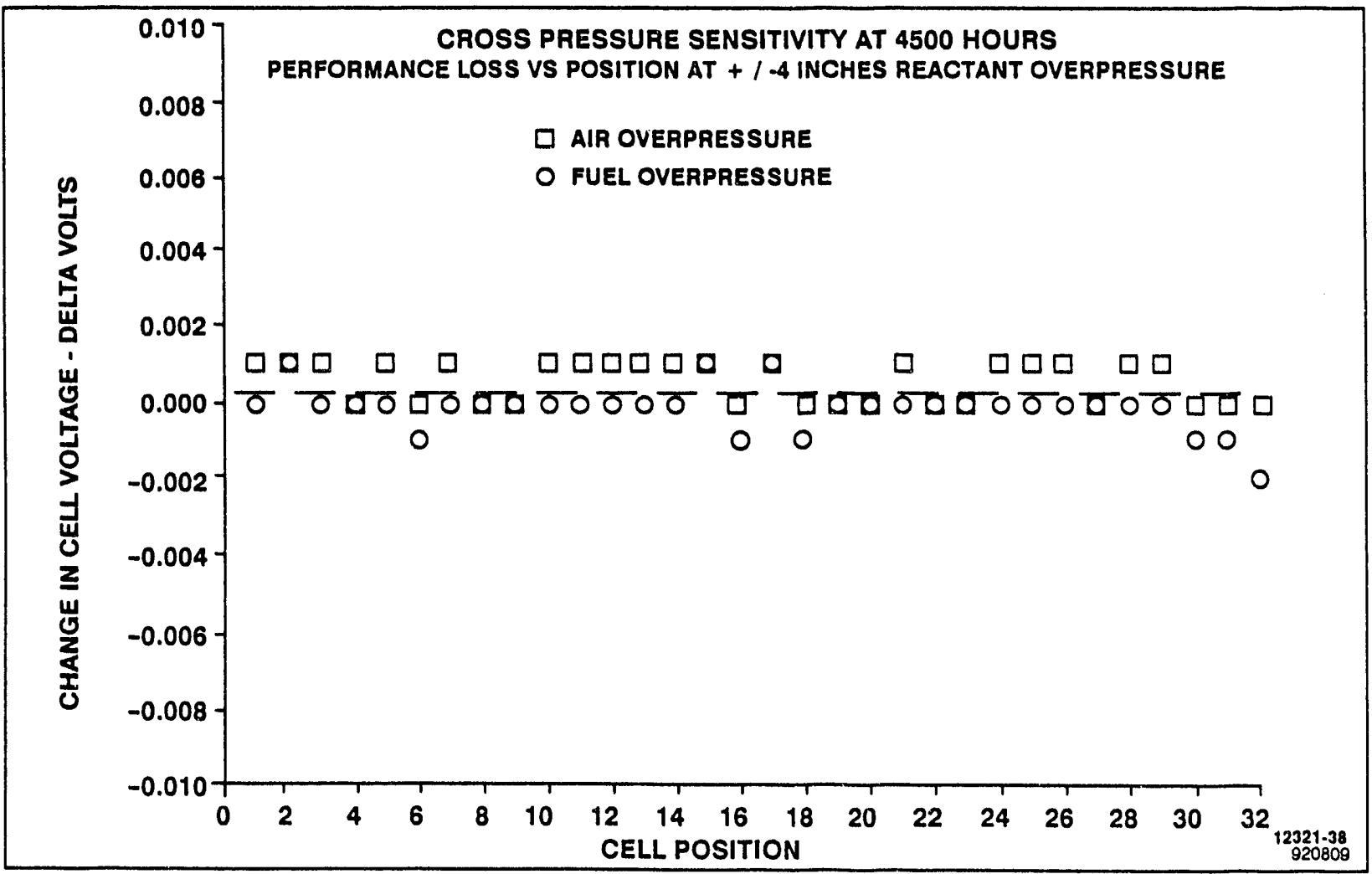

Figure 6.3-8. METC Small Area On-Site Short Stack Cross Pressure Sensitivity 


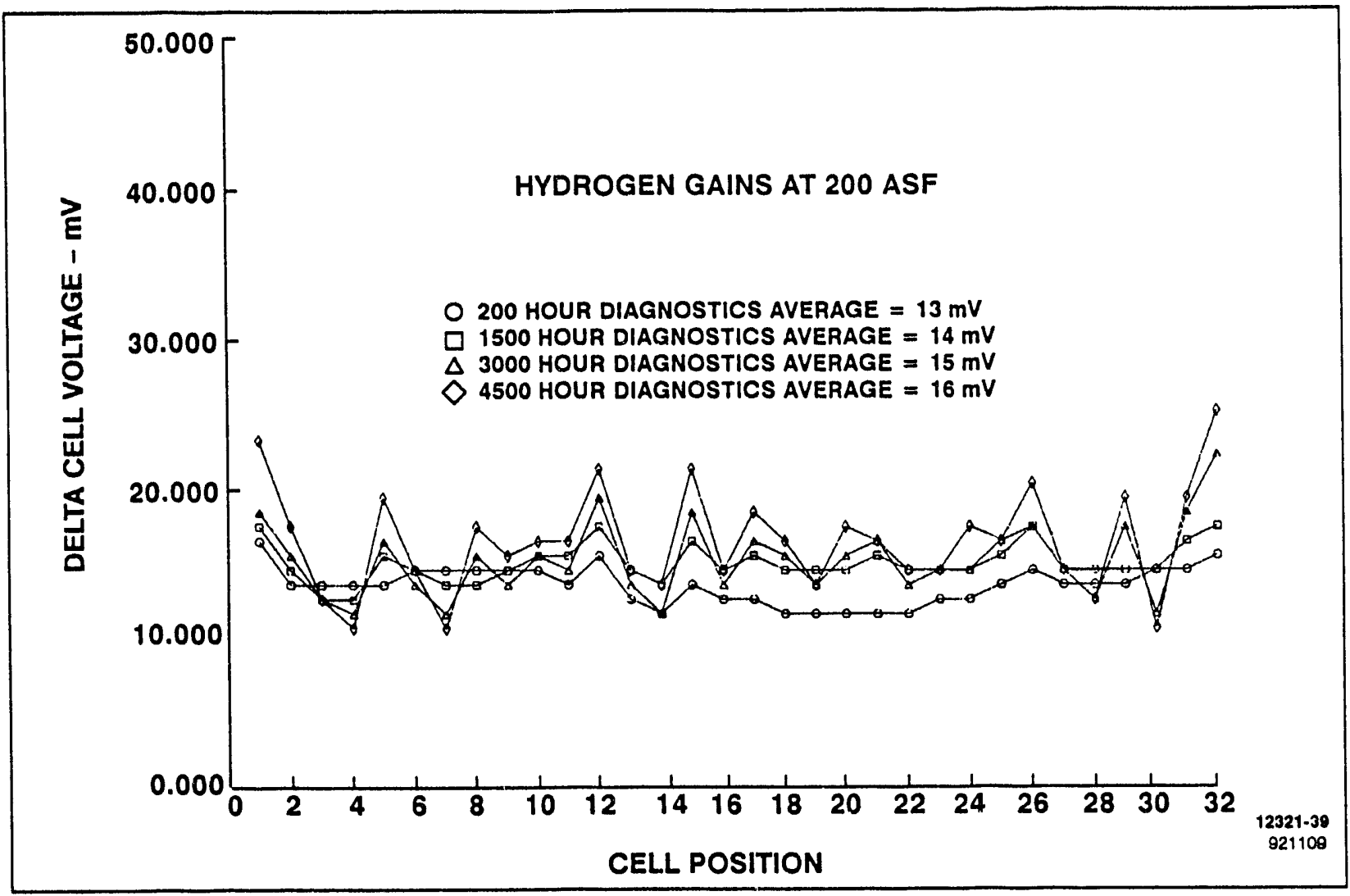

Figure 6.3-9. METC Small Area On-Site Short Stack Hydrogen Gains

(3) Post-Test Inspections

In September of 1992, near the end of the program, the short stack was subjected to various off-load diagnostics and an inspection.

Off-load diagnostics included reactant leak tests. As shown in Table 6.3-2, reactant overboard leakage and crossover was very low and stable throughout the test period.

An inspection was also conducted. Insulation was removed from one of the air exit corners ('C' corner), and the condition of substrates and coolers was checked. All parts were in visually good condition with no signs of excess acid or corrosion. The hardness of parts was similar to new parts.

\begin{tabular}{|lcc|}
\hline \multicolumn{3}{|c|}{ Table 6.3-2. Small Area On-Site Stack Reactant Leakage } \\
\hline & \multicolumn{3}{|c|}{ PPH N2 at 8 iwc } \\
& Overboard & Crossover \\
\hline Pretest & 6.9 & 0.68 \\
After 100 load hours & 2.5 & 0.33 \\
After 400 load hours & 4.3 & 1.09 \\
\hline
\end{tabular}




\section{TASK 7 - MANAGEMENT AND DOCUMENTATION}

\section{Objectives}

The objective of this task was to provide the program management necessary to maintain technical and budget control of the program activities, and to provide adequate documentation of its progress per contract requirements.

The Cost Management Reports and the Technical Progress Reports were issued in accordance with the subject contract. The following reports were submitted during the period from 1988 to 1992:

- Management Plan (FCR-09641) issued September 15, 1988

- Advanced Water Cooled Phos. Acid F/C Dev. (FCR-0941A) issued October 11, 1988.

- Monthly Cost Management Report No. 1 (FCR-09703) issued July 12, 1988.

- Monthly Technical Progress Report No. 1 April/May (FCR-09726) issued July 28, 1988.

- Monthly Cost Management Report No. 2 (FCR-09748) issued July 28, 1988.

- Quarterly Progress Report No. 2 (FCR-09779) issued August 11, 1988.

- Monthly Technical Progress Report No. 3 for July (FCR-09785) issued August 29, 1988.

- Contractor Cost Report No. 4 for August (FCR-09827) issued September 27, 1988.

- Monthly Technical Progress Report No. 4 for August (FCR-09828) issued October 13, 1988.

- Monthly Cost Management Report No. 5 for September (FCR-09918) issued October 20, 1988.

- Monthly Technical Progress Report No. 5 for September (FCR-09919) issued November 25, 1988.

- Monthly Cost Management Report No. 6 for October (FCR-09963) issued December 7, 1988.

- Monthly Technical Progress Report No. 6 for October (FCR-09964) issued January 12, 1989.

- Management Plan Suppl. for Amendment A004 (FCR-10005) issued December 12, 1988.

- Monthly Cost Management Report No. 7 for November (FCR-10032) issued November 20, 1988.

- Monthly Technical Progress Report No. 7 for November (FCR-10033) issued November 20, 1988.

- Monthly Cost Management Report No. 8 for December (FCR-10092) issued January 31, 1989.

- Annual Technical Progress Report No. 8 (FCR-10093) issued May 5, 1989.

- Monthly Cost Management Report No. 9 for January (FCR-10170) issued February 22, 1989.

- Monthly Technical Progress Report No. 9 for January (FCR-10171) issued May 3, 1989.

- Monthly Cost Management Report No. 10 for February (FCR-10226) issued March 21, 1989.

- Monthly Technical Progress Report No. 10 for February (FCR-10227) issued June 5, 1989.

- Monthly Cost Management Report No. 11 for March (FCR-10307) issued April 20, 1989.

- Monthly Technical Progress Report No. 11 for March (FCR-10308) issued June 7, 1989.

- Monthly Cost Management Report No. 12 for April (FCR-10373) issued May 18, 1989

- Monthly Technical Report No. 12 for April (FCR-10374) issued June 23, 1989.

- Monthly Cost Management Report No. 13 for May (FCR-10420) issued June 21, 1989.

- Monthly Technical Progress Report No. 13 for May (FCR-10421) issued July 27, 1989.

- Monthly Cost Management Report No. 14 for June (FCR-10497) issued July 18, 1989. 
- Quarterly Technical Progress Report No. 14 for April/June (FCR-10498) issued August 24, 1989.

- Monthly Cost Management Report No. 15 (FCR-10543) issued August 14, 1989.

- Monthly Technical Report No. 15 (FCR-10544) issued September 13, 1989

- Monthly Cost Management Report No. 16 (FCR-10588) issued September 21, 1989.

- Monthly Technical Report No. 16 (FCR-10587) issued October 24, 1989.

- Quarterly Technical Progress Report No. 17 (FCR-10669) issued November 28, 1989.

- Monthly Cost Management Report No. 17 for September (FCR-10670) issued October 17, 1989.

- Cost Management Report No. 18 (FCR-10736) issued November 21, 1989.

- Monthly Technical Report No. 18 (FCR10737) issued January 2, 1990.

- Statement of Work Revised Version (FCR-10757) issued November 21, 1989.

- Monthly Cost Management Report No. 19 (FCR-10780) issued December 18, 1989.

- Monthly Technical Report No. 19 (FCR-10781) issued February 7, 1990.

- Monthly Cost Management Report No. 20 (FCR-10835) issued February 6, 1990.

- Monthly Technical Report No. 20 (FCR-10836) issued March 6, 1990,

- Monthly Cost Management Report No. 21 (FCR-10886) issued February 23, 1990.

- Monthly Technical Report No. 21 (FCR-10887) issued March 6, 1990.

- Monthly Cost Management Report No. 22 (FCR-10950) issued March 28, 1990

- Monthly Technical Progress Report No. 22 for February (FCR-10951) issued April 30, 1990.

- Monthly Cost Management Report No. 23 for March (FCR-10998) issued April 17, 1990.

- Quarterly Technical Progress Report No. 23 for January-March (FCR-10999) issued May 16, 1990.

- Monthly Cost Management Report No. 24 for April (FCR-11065) issued May 9, 1990.

- Monthly Technical Progress Report No. 24 for April (FCR-11066) issued June 14, 1990.

- Monthly Cost Management Report No. 25 for May (FCR-11102) issued June 13, 1990.

- Monthly Technical Progress Report No. 25 for May (FCR-11103) submitted on July 17, 1990.

- Annual Summary/Milestone Schedule Plan Status Report (FCR-11129) issued June 27, 1990.

- Annual Technical Progress Report for 1989 (FCR-11131) issued July 19, 1990, 1990.

- Monthly Cost Management Report No. 26 for June (FCR-11136) issued July 31, 1990.

- Quarterly Technical Progress Report No. 26 for April-June (FCR-11137) issued July 31, 1990.

- Monthly Cost Management Report No. 27 for July (FCR-11215) issued August 22, 1990.

- Monthly Technical Progress Report No. 27 for July (FCR-11216) issued September 5, 1990.

- Monthly Cost Management Report No. 28 for August (FCR-11251) issued September 14, 1990.

- Monthly Technical Progress Report No. 28 for August (FCR-11252) issued September 21, 1990.

- Monthly Cost Managernent Report No. 29 for September 1990 (FCR-11323) issued October 16, 1990.

- Annual Summary/Milestone Schedule Plan Status Report (FCR-11349) issued October 22, 1990. 
- Quarterly Technical Progress Report No. 29 for July, August, September 1990 (FCR-11324) issued November 13, 1990.

- Monthly Cost Management Report No. 30 for October 1990 (FCR-11399) issued November 14, 1990.

- Monthly Technical Progress Report No. 30 for October 1990 (FCR-11400) issued December 4, 1990.

- Monthly Cost Management Report No. 31 for November 1990 (FCR-11441) issued December 14, 1990.

- Monthly Technical Progress Report No. 31 for November 1990 (FCR-11442) issued January 4, 1991.

- Monthly Cost Management Report No. 32 for December 1990 (FCR-11510) issued January 23, 1991.

- Quarterly Technical Progress Report No. 32 for October, November, December 1990 (FCR-11511) issued January 19, 1991.

- Monthly Cost Management Report No. 33 for January 1991 (FCR-11558) issued February 13, 1991.

- Monthly Technical Progress Report No. 33 for January 1991 (FCR-11559) issued February 19, 1991.

- Monthly Cost Management Report No. 34 for February 1991 (FCR-11613) issued February 13, 1991.

- Monthly Technical Progress Report No. 34 for February 1991 (FCR-11612) issued February 19, 1991.

- Monthly Cost Management Report No. 35 for March 19911991 (FCR-11679) issued April 26, 1991.

- Annual Technical Progress Report for April 1990 through March 1991 (FCR-11678) issued May 13, 1991.

- Monthly Cost Management Report No. 36 for April 1991 (FCR-11737) issued May 20, 1991.

- Monthly Technical Report No. 36 for April 1991 (FCR-11736) issued May 24, 1991.

- Monthly Cost Management Report No. 37 for May 1991 (FCR-11800) issued June 19, 1991.

v Monthly Technical Report No. 37 for May 1991 (FCR-11801) issued June 28, 1991.

- Monthly Cost Management Report No. 38 for June 1991 (FCR-11834) issued July 24, 1991.

- Quarterly Technical Report No. 38 for April-June 1991 (FCR-11835) issued July 24, 1991.

- Monthly Cost Management Report No. 39 for July 1991 (FCR-11902) issued August 20, 1991.

- Monthly Technical Report No. 39 for July 1991 (FCR-11903) issued August 20, 1991.

- Monthly Cost Management Report No. 40 for August 1991 (FCR-11959) issued September 1.9, 1991.

- Monthly Technical Report No. 40 for August 1991 (FCR-11961) issued September 18, 1991.

- Quarterly Technical Report No. 41 for July through September 1991 (FCR-12013) issued October 15, 1991.

- Monthly Cost Management Report No. 41 for September 1991 and the Cost Plan dated October 18, 1991 were issued October 22, 1991 (FCR-12012). 
- Annual Summary/Annual Milestone Schedule Plan Status Report (FCR-12118) issued October 18, 1991.

- Monthly Technical Report No. 42 for October 1991 (FCR-12034) issued November 15, 1991.

- Monthly Cost Management Report No. 42 for October 1991 (FCR-12033) issued November 22, 1991.

- Monthly Cost Management Report No. 43 for November 1991 (FCR-12113) issued December 6, 1991.

- Monthly Technical Report No. 43 for November 1991 (FCR-12114) issued December 16, 1991.

- The Annual Summary Report, the Annual Milestone Schedule Status Report, and the Revise Cost Plan dated 10/18/91 (FCR-12120) issued December 10, 1991.

- Quarterly Technical No. 44 for October through December 1991 (FCR-12145) issued January 29, 1992.

- Monthly Cost Management Report No. 44 for December 1991 (FCR-12146) issued February 6, 1992.

- Monthly Cost Management Report No. 45 for January 1992 (FCR-12188) issued February 14, 1992.

- Monthly Status Report No. 45 for January 1992 (FCR-12189) issued March 12, 1992.

- Monthly Cost Management Report No. 46 for February 1992 (FCR-12231) issued March 5, 1992.

- Monthly Status Report No. 46 for February 1992 (FCR-12232) issued March 31, 1992.

- Monthly Cost Management No. 47 for March 1992 (FCR-12284) issued April 22, 1992.

- Quarterly Technical Progress Report No. 47 for January through March 1992 (FCR-12285) issued May 8, 1992.

- Monthly Cost Management No. 48 for April 1992 (FCR-12326) issued May 26, 1992

- Monthly Status Report No. 48 for April 1992 (FCR-12327) issued June 4, 1992.

- Monthly Cost Management Report No. 49 for May 1992.(FCR-12355) issued June 12, 1992.

- Monthly Status Report No. 49 for May 1992 (FCR-12356) issued July 6, 1992.

- Monthly Cost Management Report No. 50 for June 1992 (FCR-12382) issued July 23, 1992.

- Quarterly Technical Progress Report No. 50 for April through June 1992 (FCR-12383) issued July 23, 1992.

- Monthly Cost Management No. 51 for July 1992 (FCR-12414) issued August 24, 1992.

- Monthly Status Report No. 51 for July 1992 (FCR-12415) issued August 24, 1992.

- Monthly Cost Management No. 52 for August 1992 (FCR-12456) issued September 14, 1992.

- Monthly Status Report No. 52 for August 1992 (FCR-12457) issued September 14, 1992.

- Final Technical Progress Report (FCR-12321A) issued September 14, 1992. 

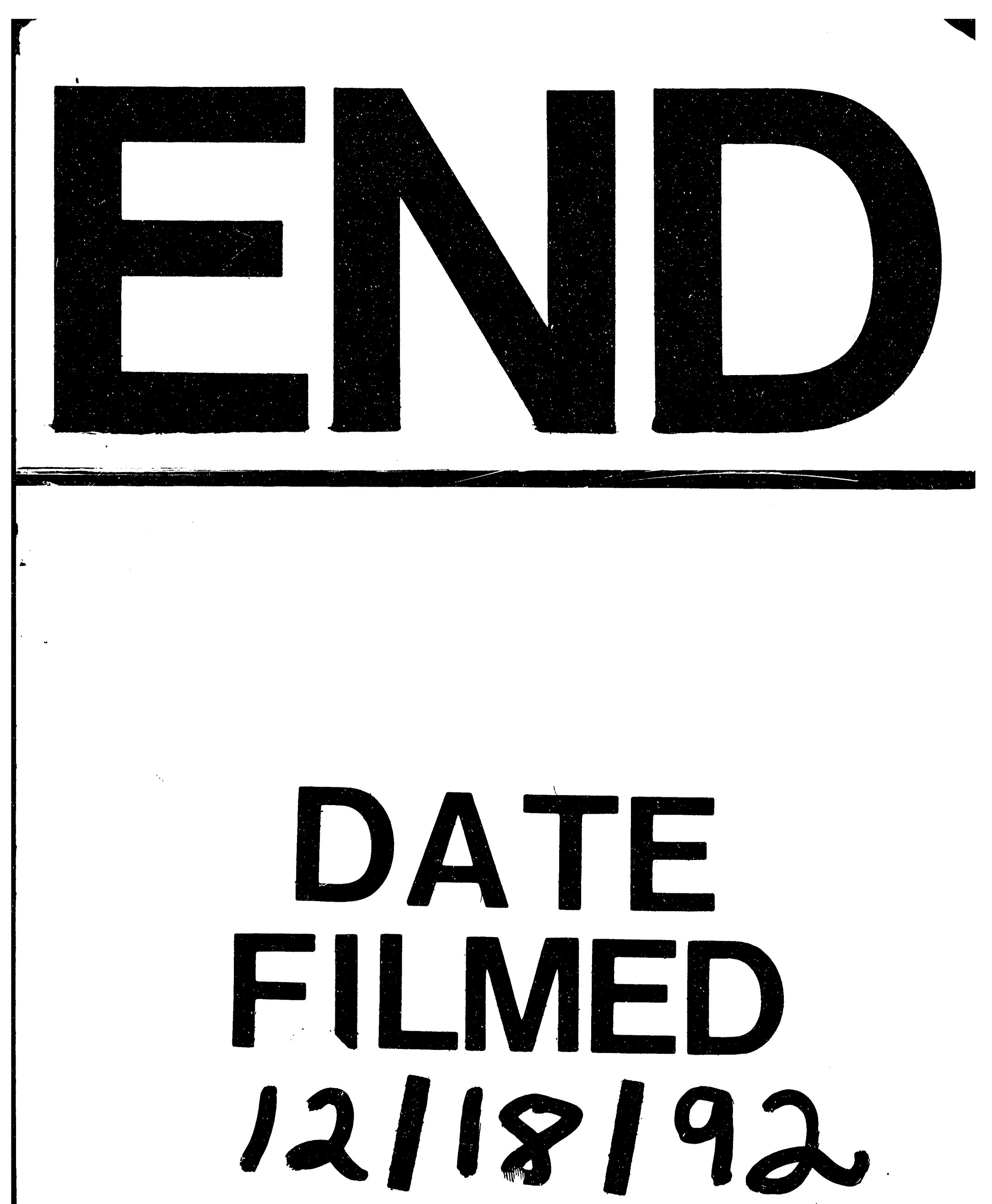
